NBER WORKING PAPER SERIES

\title{
MORTALITY, MASS-LAYOFFS, AND CAREER OUTCOMES: AN ANALYSIS USING ADMINISTRATIVE DATA
}

\author{
Daniel Sullivan \\ Till von Wachter \\ Working Paper 13626 \\ http://www.nber.org/papers/w13626
NATIONAL BUREAU OF ECONOMIC RESEARCH
1050 Massachusetts Avenue
Cambridge, MA 02138
November 2007

Contact Daniel.Sullivan@chi.frb.org or vw2112@columbia.edu. We would like to thank Marianne Bertrand, David Card, Janet Currie, Ed Glaeser, Michael Greenstone, Larry Katz, David Lee, Adriana Lleras-Muney, Claudio Lucifora, Chris Paxson, Chris Ruhm, Jon Skinner, and seminar participants at the SOLE 2006 Meetings, the NBER 2006 Summer Institute, the Milan Mills Workshop, London School of Economics, University College London (UCL), Pompeu Fabra Barcelona, Boston University, University of Illinois Urbana Champaign, Harris School, Harvard University, Columbia University Social Work, UC San Diego, UC Santa Barbara, UC Berkeley, Tufts University, Oxford University, UCL Epidemiology, Princeton University, Prague CERGEI, Catholic University of Milan, University of North Carolina Greensboro, University of Texas Houston, Texas A\&M, RWI Essen, and Columbia University for helpful comments. We would like to thank Elizabeth Weber Handwerker for sharing her programs to load the mortality data. Alice Henriques and Phil Doctor provided excellent research assistance. The views expressed herein are those of the author(s) and do not necessarily reflect the views of the National Bureau of Economic Research.

(C) 2007 by Daniel Sullivan and Till von Wachter. All rights reserved. Short sections of text, not to exceed two paragraphs, may be quoted without explicit permission provided that full credit, including (c) notice, is given to the source. 
Mortality, Mass-Layoffs, and Career Outcomes:An Analysis using Administrative Data

Daniel Sullivan and Till von Wachter

NBER Working Paper No. 13626

November 2007

JEL No. I1,J63,J65

\begin{abstract}
This paper uses administrative data on quarterly employment and earnings matched to death records to estimate the effects of job displacement on mortality. We find that job displacement leads to a $15-20 \%$ increase in death rates during the following 20 years. If such increases were sustained beyond this period, they would imply a loss in life expectancy of about 1.5 years for a worker displaced at age 40. These results are robust to extensive controls for sorting and selection, and are consistent with estimates of the effects of job loss on mortality pooling displaced workers and stayers that are not affected by selective job displacement. To examine the channels through which mass layoffs raise mortality, we exploit the panel nature of our data -- covering over 15 years of earnings -- to analyze the correlation of long-run career outcomes, such as the mean and standard deviation of earnings, with mortality at the individual and group level, something not possible with typical data sets. Our findings suggest that factors correlated with a decrease in mean earnings and a rise in standard deviation of earnings have the potential to explain an important fraction of the effect of a job displacement on mortality.
\end{abstract}

\author{
Daniel Sullivan \\ Federal Reserve Bank of Chicago \\ 230 South LaSalle Street \\ Chicago, Illinois 60604-1413 \\ daniel.sullivan@chi.frb.org \\ Till von Wachter \\ Department of Economics \\ Columbia University \\ 420 West 118th Street, 1022 IAB \\ New York, NY 10027 \\ and NBER \\ vw2112@columbia.edu
}




\section{Introduction}

A growing literature shows that what should be short-term career shocks - such as involuntary job losses or cyclical downturns - can have large and persistent effects on workers' lives. For example, displaced workers with high-seniority on the lost job tend to experience long-term earnings losses, reduced employment rates, early retirement, increased job instability, lower consumption and loss of health insurance coverage. ${ }^{2}$ Similarly, cyclical shocks can lead to persistent earnings declines and long-term increases in the variance of career outcomes, especially for younger and lower skilled workers. ${ }^{3}$ These effects have likely played a role in recent increases in earnings instability, declines in long-term employment relationships, and increases in displacement rates for high-tenured workers. ${ }^{4}$

Existing evidence suggests it is plausible that job loss would also raise mortality. A large literature documents a strong correlation of socio-economic status with health. Moreover, an increasing amount of research links stress from economic uncertainty and unemployment to unhappiness and mental health problems and a growing literature in epidemiology shows that job loss is associated with strokes and heart attacks and other detailed health measures, especially for older workers. However, while highly suggestive of an important relationship between career shocks and health outcomes, the existing evidence linking economic status and job loss to health suffers from a variety of measurement and identification problems associated with omitted variable bias and reverse causality. At present, no comprehensive study of the effect of exogenous labor market shocks on health exists, partly due to a lack of data on detailed longitudinal career and health information for a large sample of workers.

We use a large administrative longitudinal data set of individual earnings and employment histories matched to employer characteristics and individual mortality outcomes to study the effect

\footnotetext{
2 See for example Ruhm (1991), Jacobson, Lalonde, and Sullivan (1993), Chan and Stevens (2001), Stevens (1997), Gruber (1997), Olson (1992).

${ }^{3}$ E.g., Oreopoulos, von Wachter, and Heisz (2006), Oyer (2006), Kahn (2005), Hines, Hoynes, and Krueger (2002), Okun (1973).

${ }^{4}$ See for example Gottschalk and Moffitt (1994, 1998), Farber (2003), Stevens (2001), Aaronson and Sullivan (2005), Farber (2007).
} 
of workers losing their jobs as part of a mass layoff by their employer, or simply "job displacement," on their mortality rates. Following Jacobson, Lalonde, and Sullivan (1993), we use our data, spanning over 15 years of quarterly earnings and employer records from the unemployment insurance system in Pennsylvania, to identify mass-layoffs. We then follow the incidence of mortality for these workers up until 20 years after job loss and compare their mortality to that of similar workers who did not lose their job. This allows us to estimate both the short and long-term response of mortality rates to job displacement.

Our large samples allow us to compare the effect of job displacement on mortality across age and industry groups, and to engage in a thorough sensitivity analysis. Our estimates are robust to the inclusion of industry or firm fixed effects, and to controls for detailed pre-displacement career experiences. In addition, we show that our results are consistent with estimates of job loss that pool displaced workers with those not leaving the firm. These intent-to-treat type estimates are unaffected by residual selection into job loss or misclassification of job losers.

To examine the multiple channels through which job loss can affect mortality, we first study the correlation of several long-term career outcomes - such as average earnings, employment mobility, and the standard deviation of earnings - with death. We then use these results combined with additional estimates of the impact of job displacement on our measures long-term career outcomes to interpret the alternative channels of the 'reduced form' effect of mass-layoffs on mortality. In addition, we document an important correlation between displaced workers' earnings losses and their long-run subsequent mortality rates. To further gauge the importance of the earnings channel, we can also exploit predictable differences in earnings losses across groups of workers as an additional source of variation.

Our data have several advantages for our purposes. First, longitudinal information on firm size enables us to identify large changes in employment at the firm level that are plausibly exogenous to workers' own health developments. This allows us to overcome some of the problems of reverse causality and omitted variable bias in existing studies of the effect of job loss on health. Second, reliable information on death from administrative sources for a long follow-up period allows us to 
estimate the effect of job loss on an objective health measure with sufficient precision over both short and long horizons. Third, the longitudinal information on individual workers' earnings and employment allows us to construct detailed measures of long-term career outcomes and examine their correlation with mortality; we are unaware of any other study of the socio-economic determinants of mortality using such detailed career information.

We find that job displacement substantially raises mortality rates. The mortality increase is particularly high in the years immediately following job loss and then converges to a persistent positive effect of $15-20 \%$. If sustained beyond the 20 year window we can follow workers, these increases imply substantial loss of life expectancy for workers displaced in middle age or earlier. In contrast, we find little effect of job loss on mortality for workers displaced near retirement age.

These results are consistent with an initial increase in mortality from acute stress and a longterm increase in mortality from chronic stress, partly resulting from permanently lower average earnings and initial increases in the instability of earnings and employment. Given our estimates of the correlation of the mean and standard deviation of earnings with mortality, the effects of job displacement on these career outcomes could explain about $50-75 \%$ and $20 \%$ of the mass-layoff effects on long-term mortality, respectively. A comparison of groups of workers with different earnings losses confirms that a majority of the long-term increase we find could be driven by persistent earnings losses. The stress or depression caused by job displacement is likely to have additional direct effects on mortality not captured by our measures of career outcomes.

Our paper contributes to the existing literature in several ways. First, it is one of the first studies estimating the long-term effect of a plausibly exogenous labor market event on an objective measure of health for a large group of workers. It thereby helps to establish a causal link between labor market shocks and health outcomes. Second, we use a novel approach to obtain estimates of the effect of job loss that are not affected by any bias from firms selectively displacing their least healthy workers. These and an extensive sensitivity analysis confirm our results. Third, it shows how persistent earnings losses are likely to be an important channel through which layoffs permanently raise mortality rates. Last, it is the first study to provide a comprehensive analysis of the correlation 
of permanent earnings and long-term earnings and employment instability with mortality. It also provides estimates of the long-term effects of mass-layoffs on a range of career outcomes that are a contribution to the literature on the effects job displacements in their own right.

The next section gives a brief overview of the existing literature. The third section describes our approach and our data. The fourth section presents our main results, discusses the sensitivity analysis, and summarizes the implications of our estimates for losses in life expectancy. The fifth section assesses the role of alternative channels of the effect we find. The last section concludes.

\section{Literature Review: Why Should Job Displacement Affect Mortality?}

Job displacements and other negative economic events can have both direct and indirect impacts on health outcomes. First, job loss has strong effects on several economic outcomes that may influence health. A large literature has shown that job losers can experience substantial and long-lasting declines in earnings (e.g., Ruhm 1991, Jacobson, Lalonde, and Sullivan 1993, Schoeni and Dardia 2003, Couch 2006). The decline in earnings is larger for older and high tenured workers (e.g., Kletzer 1998), for workers in manufacturing, and for workers living in economically depressed areas. Job losses can also lead to substantial increases in earnings instability, by raising the propensity of non-employment and further job losses (e.g., Stevens 1997, Farber 2003). In addition, it has been shown that job losses affect consumption (Gruber 1997, Browning and Crossley 2001), and access to health insurance (Olson 1992). The incidence of job loss and the variance of transitory and permanent earnings shocks have been increasing since the mid-1980s, especially among older and high-tenured workers (e.g., Aaronson and Sullivan 1998, Farber 2003, Gottschalk and Moffitt 1994, 2002). ${ }^{5}$

A separate strand of literature documents a significant correlation of income with health and mortality. Indeed, at face value, the existing estimates of the impact of income on health would imply a strong effect of job loss on mortality (e.g., Deaton and Paxson 1999). However, such

\footnotetext{
${ }^{5}$ Similarly, a growing literature shows that economic conditions in the local labor market and the firm have long term effects on workers' earnings and career instability. Cyclical swings have highly persistent effect on earnings (e.g., Oreopoulos, von Wachter, and Heisz 2006, Kahn 2006, Oyer 2006), and have lasting effects on job mobility and job quality, especially for less-advantaged workers (e.g., Oreopoulos et al. 2006).
} 
estimates may be biased due to reverse causality running from health to income, omitted worker characteristics, and measurement error. ${ }^{6}$ These difficulties have led recent observers of the literature to deemphasize the effect of income on health in favor of more lasting individual traits such as education (e.g., Cutler, Deaton, and Lleras-Muney 2006). There are indeed few studies of the effect of income on health with a research design that allow identification of a causal relationship. ${ }^{7}$ Yet, even if there is no direct effect of earnings on health, earnings losses due to job displacement are still likely to capture the worsened life conditions of job losers through reduced health insurance, less consumption, or increased earnings instability.

In addition to indirect effects running through income, earnings instability, or access to health insurance, job displacement may also have direct effects on well-being. A large literature in economics and sociology has shown that unemployment correlates strongly with the incidence of depression, low self-esteem, unhappiness, and even suicide. ${ }^{8}$ While some of these outcomes are conceivably due to lower income, some of them may derive from factors independent of the earnings situation. Similarly, several authors in sociology, social work, and epidemiology have analyzed the effect of job loss on mental and physical health. These studies use either longitudinal data with health and career information, such as the Health and Retirement Survey (HRS), or study the effect of single plant closures (see Burgard, Brand, and House 2005 for an excellent survey). Most prominently, a series of studies using the HRS has found increased incidence of adverse health outcomes such as heart attacks or strokes among older job losers (e.g., Gallo et al. 2000, 2006). A smaller set of studies has analyzed randomized trials to study the effect of alternative forms of assistance to job losers on job search, employment, and health outcomes (e.g., Price, Choi, and Vinokur 2002).

\footnotetext{
${ }^{6}$ Another important question is regarding the source of any true income effects of health; these might arise from lack of access to health improving investments, or from effects through social-status and relative deprivation (e.g., Deaton 1999, Miller and Paxson 2001).

${ }^{7}$ An exception is a recent experimental study analyzing lottery winners in Sweden that confirms a significant causal relationship running from income to health (Lindahl 2005).

${ }^{8}$ E.g., see papers summarized in Darity and Goldsmith (1996) and Burgard, Brand, and House (2005).
} 
Several recent studies based on European data have analyzed the effect of job loss on health using administrative data on earnings, firm sizes, and health outcomes. These studies find contrasting results on mortality and outcomes such as mental health, with some indicating significant negative effects of job loss on longevity. ${ }^{9}$ Important methodological differences aside, it is difficult to compare the results from these studies to ours, since the underlying experience of job losers is so different. Most European countries have generous unemployment insurance and welfare programs and have universal health insurance coverage. As a consequence, studies of job displacement in Europe often find much smaller and short lived effects on earnings losses than is the case for our sample of job losers in Pennsylvania from the early to mid 1980s. ${ }^{10}$

Although the current estimates of job loss on health outcomes indicate that there are potentially significant effects on health even after controlling for pre-job loss characteristics such as health and socio-economic status, they suffer from several potential drawbacks. Most importantly, since an important body of literature shows that job loss is in itself affected by poor health (e.g., Smith 2003) special care has to be taken to avoid selection bias (Gibbons and Katz 1991). While several studies focus on workers displaced by plant closing and try to control for background characteristics, selection problems remain even for workers displaced in plant closings. ${ }^{11}$ Another concern is that health environments differ across sectors and firms, possibly attracting different types of workers. Thus, it is important to analyze the effect of job loss within sectors, and to control for the sorting of workers between firms (von Wachter and Bender 2006). Finally, recent studies typically focus on older workers, possibly missing the effects of more long-lasting exposure to low income and chronic stress from earnings instability due to job loss earlier in workers' careers.

\footnotetext{
${ }^{9}$ Eliason and Storrie (2004) find male workers losing their jobs in establishment closures in Sweden experience excess mortality for up to ten years after job loss. Martikainen, Maki, and Jantti (2007) find no such effects in Finland. Similarly, while for example Kuhn, Lalive, and Zweimueller (2007) find that job loss reduces mental health of men in Austria, Browning, Dano, and Heinesen (2007) find no such effects in Denmark.

${ }_{10}$ Not many studies analyze the effect of job loss on earnings in Europe, the focus being more often employment effects. Of those analyses that study wages, there is considerable heterogeneity in approaches and results. For example, the effects of job loss on earnings in Austria are very small (Card, Chetty, and Weber 2006). Earnings losses in Sweden have been found to be short lived (Ohlsson and Storrie 2006) or persistent (Eliason and Storrie 2007), depending on the sample used. See von Wachter (2007) for a survey of literature on the cost of job displacement in the U.S. and Europe. 11 This is because plant closings are more likely to occur in smaller firms that pay less and attract different employees (Krashinsky 2002).
} 
An important part of the difficulty in studying the effects of exogenous career shocks such as a job displacement on health is the lack of proper data. Studies based on survey data sets have difficulty isolating events at the firm level that are a plausibly exogenous source of job loss. ${ }^{12}$ In addition, small samples prevent the inclusion of industry or firm fixed effects and make it difficult to deal with remaining selection. Small samples and short follow-up periods also preclude the separate study of short- and long-run impacts of job loss on health or the analysis of differences in the effect for alternative groups of workers. Similarly, previous studies do not have good measures of permanent income and other long-term career outcomes such as earnings instability. This makes it difficult to assess the effect of alternative channels of the job loss effect on health. ${ }^{13}$

Obtaining information on the effect of individual level career shocks such as job displacement is also important since influential recent studies have shown that reduced economic activity during recessions actually reduces mortality. In a seminal study, looking at outcomes across U.S. states, Ruhm (2000) reports that mortality declines during economic downturns, perhaps because workers have more time to invest in their health, reduce risky health behaviors such as smoking, and face fewer car and work-related accidents. ${ }^{14}$ This suggests that job loss could have some beneficial effect by reducing accidents and possibly risky health behavior. ${ }^{15}$ We will explore the role of non-employment directly in Section 5. However, while our study of mass-layoffs can provide additional information on possible channels operating at the macro level, care has to be taken when

\footnotetext{
${ }^{12}$ Instead they have to rely on workers' self-reports that have been shown to be affected by measurement error. See Hildreth, von Wachter, and Weber (2005) and studies cited therein.

13 The best income data currently available for studies of health in the U.S. comes from the Current Population Surveys, which provide information only on income in the year prior to the survey with little longitudinal information on careers or employers. This can lead to a downward bias in estimates of the impact of permanent income on mortality due to classical measurement error arising from respondents' inaccurate reporting (Bound and Krueger 1991) as well as an error in approximating permanent income by current income (e.g., Haider and Solon 2006).

${ }^{14} \mathrm{Ruhm}$ (2000) regresses mortality rates by causes at the state-year level on state unemployment rates controlling for state and year fixed effects. The largest responses are obtained for vehicle deaths, other accidents and suicide, and for 'preventable causes' (such as heart or liver disease), with the effect of vehicle deaths five times larger than that of 'preventable causes.' Due to the large share of preventable causes in overall death rates, these causes explain about $40 \%$ of predicted mortality, whereas all accidents explain about $25 \%$ of predicted mortality.

15 On the other hand, comparing cohorts before and after the Social Security 'Notch', Evans and Snyder (2002) suggest that reduced economic activity may negatively affect health outcomes for older workers, perhaps due to a loss in social status or purpose. However, Weber-Handwerker (2007) shows these results may partly arise from overall cohortdifferences in mortality.
} 
comparing the two approaches. First, the event we analyze is of different nature than the aggregate variation used in Ruhm (2000). Only a fraction of reallocation of employment in recessions occurs through job separations and mass-layoffs, and these are often concentrated in particular regions, sectors, or groups of workers. Second, we analyze affects associated with earnings losses exceeding what is typically observed in an economic downturn or in the career of an average worker. Thus, the beneficial effects from a lower rate accidents or improved health behavior in a recession may be more than offset by the large negative effects of job loss on workers' careers in our sample. ${ }^{16}$

\section{Empirical Approach: Mortality, Career Outcomes, and Mass Layoffs}

In the present paper, we merge two large administrative data sets to study the effects of career outcomes and exogenous labor market shocks on mortality. Specifically, panel data on individual earnings and employment information is merged with administrative data on the date of death. The former is derived from the unemployment insurance records of the state of Pennsylvania and covers male workers from the period from 1974 to 1991 . The latter is derived from a database compiled by the Social Security Administration and covers deaths between 1974 and $2002 .{ }^{17}$ The combined data set has several attractive features. First, it allows us to identify largescale layoffs at the firm level that constitute plausibly exogenous shocks to workers' career development. Second, an extended period of follow-up using administrative data provides us with reliable and rich information on mortality patterns. In particular, since we examine displacements occurring in the early 1980s we can trace both the short and long-term effects of job loss on mortality. Third, our large samples allow us to implement estimation strategies dealing explicitly with sorting and selection. Fourth, the long time period covered by the data allow us to better examine the effect of career outcomes such as permanent earnings or earnings stability on mortality.

\footnotetext{
${ }^{16}$ We would like to thank Chris Ruhm for helpful feedback on these questions.

17 The Social Security Administration's Death Master File (DMF) is described and evaluated in Hill and Rosenwaike (2002). Coverage of the death data is better in the 1990s, for older workers, and for men. Recent work comparing the DMF with complete mortality data from the National Center for Health Statistics (cited in Weber-Handwerker 2006) suggests coverage for men is between $80-90 \%$ before age 65 , and above $95 \%$ after age 65 . We replicated these tabulations for deaths in Pennsylvania from 1980-2002 and find similar results (in the main sample, we also include deaths occurring in other states).
} 
Our empirical analysis proceeds in four steps. First, we analyze the effect of job displacement on short and long-run mortality rates for different samples and workers, including a thorough sensitivity analysis dealing with selection, sorting, and misclassification. In a second step, we analyze differences in the long-term effect of job loss on mortality by age and industry, and use these estimates to provide an assessment of the losses in life-expectancies arising from mass-layoffs. Third, we use our data to provide estimates of the correlation of mortality with detailed measures of permanent earnings and other long-term career outcomes, factors not previously analyzed in the literature on mortality and socio-economic status. Together with new estimates of the long-term effects of job loss on a range of career outcomes, these results to give a first assessment of alternative channels underlying the effect of job loss on death. Fourth, we document the relationship between earnings changes due to job displacement and mortality, and use predictable differences in earnings losses across groups in the population to gain further insight into the channel of the effect of job displacement on mortality.

\subsection{Structure of Sample}

To analyze the effect of job loss and other career outcomes on mortality, we divide our sample into a baseline period (1974-1979), a mass-layoff period (1980-1986), and a follow-up period. The follow up period ranges from 1980-2002 or 1987-2002, depending on the sample we use. We then analyze the probability of dying each year in the follow-up period as a function of job loss in the mass-layoff period and of career outcomes in the baseline period. This structure has several advantages. Separating the baseline period and the job loss event from the follow up period reduces the bias from reverse causality running from health to income or job loss. It also replicates important features of the well-established research design of the paper on the effects of mass-layoff by Jacobson, Lalonde, and Sullivan (1993) further discussed below. In addition, it allows us to replicate existing studies of the effect of income on mortality (e.g., Deaton and Paxson 1999, see our Appendix Table 5). 
We define job displacement exactly as in Jacobson, Lalonde, and Sullivan (1993) (henceforth JLS). Specifically, we identify the workers who left their employer at the same time that the employer experienced a $30 \%$ or larger decline in employment. We work with three main samples that each satisfy a common set of restrictions, but differ in the degree of labor force attachment they require. Following JLS, both samples focus on workers born between 1930 and 1959 who lost their job between 1980 and 1986 after having remained with the same employer in the period from 1974 to 1979. The first sample makes no restrictions on employment after 1979 or the control group, and thus simply compares mortality of workers who lost their job in the displacement period to all other workers. For these workers, we analyze the incidence of death from 1980 to 2002. ${ }^{18}$

Our second sample is the sample used by JLS in their analysis of long-term earnings losses. It differs from the first by focusing on workers who remained highly attached to the Pennsylvania labor force as evidenced by positive reported earnings in each year 1980 to 1986. Since we only observe earnings information for workers who remain in PA, this allows us to consider various career outcomes such as earnings losses as potential channels of the displacement effect. By focusing on high-attachment male employees this sample also limits the underlying heterogeneity of workers in our main samples. In addition, as in the earlier paper, when working with this sample we also drop non-mass layoff separators for whom displacement status is not as well measured in our data. We also consider an intermediate sample with weaker restrictions on labor force attachment after job loss. Since the labor force attachment requirement obviously implies workers are alive through 1986, for these samples the follow up period starts in 1987. In addition, to explore the role of age at job loss, we replicate our analysis including workers born between 1920 and 1929.

\subsection{Main Estimation Strategy}

Using these samples, we estimate several logistic models of the annual probability of dying as a function of an indicator for whether a worker left his 1974-79 employer during a mass-layoff

occurring from 1980-1986 $\left(M L F_{i}^{80-86}\right)$, prior career information $C_{i}^{74-79}$ measured over the horizon

\footnotetext{
${ }_{18}$ Mortality data comes from the Social Security Administration and is not limited to deaths that occur in Pennsylvania.
} 
1974 to 1979 (the baseline period), as well as controls for age and calendar year. The model we estimate can be represented as

$$
\ln \left(\frac{p_{i t}}{1-p_{i t}}\right)=\pi C_{i}^{74-79}+\gamma M L F_{i}^{80-86}+\chi_{a}+\phi_{t}
$$

where the annual probability of dying in year $\mathrm{t}$ given survival until year $\mathrm{t}-1$ (the hazard function), $p_{i t} \equiv \operatorname{Pr}\left\{\right.$ Death $_{i t}=1 \mid$ Death $\left._{i t-1}=0\right\}=\Lambda\left(x^{\prime} \beta\right)$, is measured over the follow-up period. ${ }^{19}$ All specifications include year dummies, and we alternatively model the role of age $\left(\chi_{a}\right)$ as a $4^{\text {th }}$ order polynomial or as separate age dummies (with little difference in results). The coefficient on the $M L F$-dummy measures the overall increase in the log odds of dying in a year due to job displacement.

Given that the probability of death is typically quite small, the log-odds ratio approximates the log of the death rate itself, and the coefficients have an approximate interpretation as percentage changes of the probability of death. In addition, we report the proper marginal effects on death probabilities that control for the curvature of the logistic distribution. The marginal effects will be higher for groups of workers who tend to have higher mortality, such as older or low-income workers. We have also made sure that the logistic functional form did not drive our estimates; all results are evident in straightforward tabulations of average mortality rates and in linear probability models. $^{20}$

Since the shock that triggers job loss in this analysis occurs at the firm level, it should be exogenous to workers' own health problems. However, it is possible that the firm lays off its least productive workers, who may in turn be in poor health. To address this potential problem we control for the mean and standard deviation of earnings in the baseline period, with little difference in results. To further control for differences among job losers and stayers we also included other

\footnotetext{
${ }^{19}$ The cumulative distribution function of the extreme value distribution is $\Lambda\left(x^{\prime} \beta\right)=\exp \left\{x^{\prime} \beta\right\} /\left(1-\exp \left\{x^{\prime} \beta\right\}\right)$. Workers contribute one observation for each year that they are alive from either 1980 or 1987 to 2002.

${ }^{20}$ Note that once we include interactions of MLF-dummy with dummies for years since job loss, the logit specification estimates the hazard function (see Efron 1988).
} 
career characteristics such as earnings growth and non-employment spells. ${ }^{21}$ Similarly, to account for underlying differences in average mortality rates and mass-layoff rates across sectors our baseline specification controls for one-digit industry effects. Thus, our flexible baseline specification is

$$
\ln \left(\frac{p_{i t}}{1-p_{i t}}\right)=\delta M L F_{i}^{8-86}+\pi \ln \left(\overline{q e a r n}_{i t}{ }^{74-79}\right)+\gamma S D\left(\ln \left(\text { qearn }_{i t}\right)\right)^{74-79}+\chi_{a}+\phi_{t}+\psi_{j}
$$

where qearn stands for quarterly earnings as measured by unemployment insurance records, and $\psi_{j}$ represent six industry dummies. To account for the possibility that workers of different ability and health outcomes might be sorted into firms with different rates of mass-layoff, we also replicate all our results including fixed effects for workers' employers. ${ }^{22}$ This compares the short and long-term mortality for workers from the same firm with similar age, average career earnings, and variability and, should be robust to selection within and between employers. We address the potential for remaining selection directly below.

To examine the source of the effect we estimate, we also estimate interactions of the MLFdummy with age at layoff and initial industry. In particular, we are interested in how the mortality effects of job loss vary with age at displacement. Older workers face potentially higher immediate losses due to difficulties of re-integrating in the labor market, but the reduced earnings may occur over a shorter period, limiting the life-time earnings reduction. Similarly, we are interested in whether the results are driven by layoffs from particular sectors, or whether workers losing jobs in traditionally 'unhealthy' sectors actually benefit from the layoff.

We also consider the evolution of the mortality effect with years since layoff to distinguish between initial and long-term effects. This is of particular interest since in our analysis of the effect of job loss on career outcomes we find that there are important short term responses in a wide range

21 This also helps to control for the fact that the logarithm of earnings is not defined for quarters of zero earnings. 22 A long literature suggests that more able workers are sorted into larger higher-paying firms. That such sorting behavior can bias estimates of the effects of layoffs has been shown by von Wachter and Bender (2006). Since in PA in the early 1980s downsizing occurred in traditionally high-wage manufacturing sectors, this may mean that workers in mass-layoff firms may be of above average earnings potential and health. 
of career outcomes. However, the only effect remaining past four years after a job loss is a sizeable reduction in earnings.

\subsection{Sensitivity: Selection and Misclassification}

Most estimators of the effects of job loss face the problem that certain types of workers may be sorted into firms with higher layoff risk and that the firm selectively displaces certain kinds of workers (von Wachter and Bender 2006). While in the analysis of earnings the potential biases from sorting and selection can be controlled for by the inclusion of worker fixed effects (e.g., Jacobson, Lalonde, Sullivan 1993), this is not possible in the case of mortality. Our basic estimates control for sorting by including industry or firm fixed effects and for selection with an extensive set of longterm pre-layoff career outcomes that are related to productivity (and thereby to the firm's selection criteria), such as the average, trend, and variance of earnings and employment. Moreover, the scope for selective displacement was limited in the period we study because many firms - especially in manufacturing where our layoffs are concentrated - were constrained by seniority rules. This held whether the firm was unionized or not (Abraham and Meadoff 1984).

Nevertheless, we develop two strategies to directly address the concern that firms may still have information on workers' underlying health status and selectively dismiss the least healthy. First, we use a novel strategy to estimate the costs of job loss that directly avoids the problem of selective job displacement by pooling the sample of displaced workers with those not displaced. The pooled estimator compares the short and long-term mortality rate of all workers present in firms that experience a mass-layoff with similar workers at non-mass layoff firms in the same industry. If we were to treat a mass-layoff at the firm level as an instrument for individual job loss, this would be the reduced form estimate, also known as the intent-to-treat estimator. ${ }^{23}$ Thus, to compare the resulting estimates to those in the main tables, we have to rescale it by dividing by the effect of mass-layoff on job loss.

\footnotetext{
${ }^{23}$ Von Wachter and Bender (2006) discuss the problems of sorting and selection in job loss estimates when fixed effects cannot be used and discuss alternative instrumental variable strategies using layoffs at the firm-occupation level as instruments for job loss.
} 
Second, if there is selection, the degree of bias should be related to the size of the layoff; i.e., the larger the layoff, the less selective should be the sample of job losers. We thus analyze the effect of job loss at mass-layoffs by size of layoffs. The caveat in such an analysis is the concern that larger layoffs and closures are typically experienced by smaller firms that also attract less able workers and provide less desirable career environments. Similarly, layoff rules such as a seniority rule are less likely to bind in larger layoffs, suggesting caution when interpreting this sensitivity check.

Another potential concern is that workers dying around the layoff date are automatically classified as job losers. A straightforward calculation shows that the approximate misclassification bias is expected to be small because the average mortality rate is small. ${ }^{24}$ Another advantage of the pooled estimator is that it is robust to such mechanical misclassification. An additional concern that has found little attention in the literature on job loss is that no true measure of involuntary job loss is available, and displacement is approximated using firm level events. This may lead to some degree to misclassification of voluntary movers as job losers (Hildreth, von Wachter and Weber 2005). The pooled estimates do not suffer from this ambiguity in interpretation.

\subsection{Sources of the Mass-Layoff Effect on Mortality}

As discussed in Section 2, job loss is likely to affect mortality through a variety of channels. We take three approaches to gauging the effect of those channels running through career outcomes. In the first approach, we show that job loss has strong effects on average earnings and career instability. We then combine such estimates with estimates of the association of these long-term career outcomes with mortality to see how much of the effect of job displacement on mortality can be explained by its effects on the mean and standard deviation of earning. In a second approach, we address the potential correlation of the response to job loss with underlying health status by

\footnotetext{
${ }^{24}$ If $\beta$ is the true difference in mortality rates of job losers and stayers, then one can show that the actual comparison is a weighted function of the true mortality gap and the difference between the actual mortality of stayers $\left(\delta_{2}\right)$ and the mortality of misclassified stayers (which is equal to one). The weight is the misclassification probability $q=\operatorname{Pr}\left\{D^{*}=0 \mid D=1\right\}$; i.e., we have that the probability limit of the simple difference in mortality rates of job losers and stayers is $b=\beta(1-q)+\left(1-\delta_{2}\right) q$. The misclassification rate $q$ can itself be approximated as a function of the overall mortality rate and the fraction of job losers, and turns out to be very small under reasonable scenarios.
} 
exploiting differences in predicted earnings impacts of displacement at the cell-level. Third, to learn more about the cumulative effect of lower earnings due to mass-layoff on health, we assess the potential of life-time losses in earnings in explaining the loss in total life expectancy due job displacement.

In the first approach, we exploit the large sample sizes and limited degree of top-coding of quarterly earnings information in the unemployment insurance records to examine the correlation of long-term earnings and mortality; we also use our results to gauge the role of two important sources of measurement error afflicting estimates of the income-death correlation based only on survey measures of a single year of income - classical measurement error affecting surveyed earnings, and the mis-measurement of permanent earnings by current earnings. We then analyze the effect of various measures of instability over worker's careers, among others the standard deviation of earnings, number of quarters worked, number of transitions between jobs and into nonemployment, or the number of large earnings declines. The correlations we obtain should not be afflicted by short term reverse causality or strong measurement error. However, we do not interpret the results as a causal link between career earnings outcomes and mortality since they may still be affected by omitted variable bias.

In a second step, we estimate the effect dynamic effects of losing a job displacement on annual earnings, the variability of earnings, non-employment, job changes, industry changes, and regional mobility. ${ }^{25}$ The results can be combined with the correlations obtained from models as in equation (2) to interpret the sources of the effects estimated from the effects of mass-layoff on

\footnotetext{
25 We do this by re-estimating the distributed lag model used by JLS with different career outcomes as the dependent variable. The model we estimate at the annual level is

$$
y_{i t}=\alpha_{i}+\gamma_{t}+\beta X_{i t}+\sum_{k \geq-m,} \delta_{k} D_{i t}^{k}+u_{i t}
$$

where the outcome variable $y_{i t}$ represents a measure of annual earnings or another career outcome, the time dummies $\gamma_{t}$ are identified by the presence of 'stayers' (i.e., workers not losing their job), and the error $u_{i t}$ represents truly random components affecting the outcome. The coefficients $\delta_{k}$ on the dummies indicating the k-th period before, during, or after job loss $\left(D_{i t}^{k}\right)$ measure the time path of earnings changes of job losers before and after a displacement relative to the baseline and the control group. The displacement effect is identified by the inclusion of workers staying at their employers throughout the period under study (the comparison group).
} 
mortality (estimated in model (3)). Clearly, this does not allow an exact decomposition of the effect, since the correlations may not represent causal estimates, but it will allow us to obtain important insights regarding the potential magnitudes of the likely importance of alternative channels.

To go beyond the basic approximation in assessing how much of the mass-layoff effect can be explained by variation in earnings, ideally we would like to control directly for individual earnings losses in our model of mortality. We thereby face the common problem that although a mass-layoff (MLF) provides a valid quasi-experimental design for the overall effect of a job loss on mortality, it may not in itself provide sufficient identifying variation to estimate the effect running through alternative channels such as earnings losses.

Specifically, we would like to directly estimate the following augmented logit model for the annual hazard of death after a MLF

$$
\ln \left(\frac{p_{i t}}{1-p_{i t}}\right)=\chi_{a}+\phi_{t}+\beta M L F_{i}+\pi \ln \left(\bar{y}_{i}^{74-79}\right)+\gamma \Delta \ln \bar{y}_{i}
$$

where $\Delta \ln \bar{y}_{i} \equiv \ln \left(\bar{y}_{i}^{87-91}\right)-\ln \left(\bar{y}_{i}^{74-79}\right)$ is the earnings change during the mass-layoff period. ${ }^{26}$ This model yields consistent estimates if the change in earnings is uncorrelated with other factors resulting in higher mortality rates. If this were true, the resulting estimates would tell us how much earnings changes affect mortality, and to what extent any of the MLF effect is left conditioning on the earnings change. However, we may be concerned that part of the response to MLF in earnings may itself be driven by underlying health conditions that also affect mortality. For example, even though job losers are on average as healthy as stayers, physically frail job losers may both have high earnings losses and die earlier.

An alternative approach is to find an additional source of variation that helps to determine the response of alternative channels to MLF. For example, if different observable labor force groups experience predictably different earnings losses due to job displacement, we can use this source of

\footnotetext{
${ }^{26}$ This model is a special case of a more general model where current and past earnings have flexible dynamic effects on mortality. Since little is known about the true relationship between life-time earnings and mortality, after experimenting with alternative specifications, we have settled on (implicitly) age-adjusted medium-term averages of earnings as a sensible representation of the underlying functional form.
} 
variation to re-estimate equation (3). As further explained in Section 5, since existing theory and evidence suggest there are permanent wage differentials along these dimensions, we will use groups based on alternative combinations of age at job loss, average earnings prior to job loss, region, and industry of displacement. Note that were we to interpret these as causal estimates of earnings on mortality, we have to be willing to assume that there are no other responses to MLF at the group level correlated with both earnings and mortality. ${ }^{27}$ However, there may still be group-level responses that drive both earnings and mortality. For example, differential rates of depression across groups may affect both earnings capacity as well as long-term mortality outcomes. Instead, we interpret the resulting estimates as an additional descriptive measure of the correlation of earnings losses at MLF and increases in mortality among job losers. Note, however, that a general effect of mass-layoff on stress or depression does not affect group level estimates.

To implement the group level model, we first include group-level dummies $\left(D_{i}(i \in c)\right)$ and their interaction with the MLF dummy in a model for earnings after a job loss (modeling the changes in average earnings is equivalent)

$$
\Delta \ln \bar{y}_{i}=\delta_{a}+\pi_{t}+\pi \ln \left(\bar{y}_{i}^{74-79}\right)+\sum_{c=1}^{C} \theta_{c} D_{i}(i \in c)+\sum_{c=1}^{c} \psi_{c} D_{i}(i \in c) M L F_{i}+u_{i}
$$

To implement our strategy using a linear probability model of mortality we then use the fitted value from this regression to replace the individual earnings change in equation in model (4). Equivalently, we estimate the linear reduced form equation for mortality

$$
p_{i t}=\chi_{a}+\phi_{t}+\beta M L F_{i}+\pi \ln \left(\bar{y}_{i}^{74-79}\right)+\sum_{c=1}^{C} \gamma_{c} D_{i}(i \in c)+\sum_{c=1}^{C} \lambda_{c} D_{i}(i \in c) M L F_{i},
$$

and run a linear regression of the dummies on the interaction in the reduced form and the first stage, properly weighted. The resulting slope coefficient would be the IV estimator for the earnings loss if the interactions of mass-layoff and group dummies were to be used as instrument for earnings. The sum of squared errors of the group level model divided by the number of groups is the test statistic

\footnotetext{
${ }^{27}$ The intuition for identification in the cell-level model is parallel to that at the individual level model. I.e., we obtain consistent estimates if there are no group level error components correlated with both group level earnings losses and mortality.
} 
of a Chi-Squared test for the validity of the group-level dummies as instruments. Although we do not treat our group-level estimates as two stage least squares estimates since we cannot exclude other group level changes affecting both earnings and mortality, we will exploit this interpretation below. ${ }^{28}$

The cell-level analysis misses potential cumulative effect of reduced career opportunities and earnings on mortality. The long-term increase in the hazard of death we find suggest the loss in lifeexpectancy might be a useful alternative summary measure of the effect of job loss on mortality. Thus, we use our estimates of the decline in life-expectancy by age- and industry-groups combined with estimates of the present-discounted value of life-time earnings estimates to provide an additional group-level estimate of the potential role of career losses in earnings on long-term health outcomes.

\section{Mass Layoffs, Career Outcomes, and Mortality}

\subsection{Mass-Layoff, Job Loss, and Mortality}

Table 1 shows the workers' average characteristics in the pre-period (1974-79) by layoffstatus for our least and most restrictive samples. As discussed by Jacobson, Lalonde, and Sullivan (1993) [JLS], job losers are somewhat younger and have slightly lower average earnings. They also have higher earnings growth and lower variance; they tend to come from larger establishments and from the manufacturing sector. These patterns suggest it is important to control for potential differences across sectors and firms, but also for pre-job loss differences in career outcomes among movers and stayers. Note that the two samples are very similar from 1974-79, but differ in the aftermath; the sample of job losers without work restriction have much larger average earnings losses and about double as many quarters of non-employment.

Appendix Table 1 shows additional characteristics of our two main samples of male workers for every two years of the follow up period. The typical worker is in middle age at the time of layoff, and the sample ages over time. We capture these differences by controlling for age in our log-odds

\footnotetext{
28 See Angrist (1991) for a detailed exposition.
} 
models. ${ }^{29}$ Our sample sizes are substantial, but given the overall mortality rate is low the number of deaths every year is sufficient for the main analysis, but not large. This limits the number of detailed interactions we can estimate. There is some attrition as the sample ages, but the pattern of average quarterly earnings suggests it is not selective. The last column shows the layoff rate, which at 30$35 \%$ is higher than in the U.S. population because our focus on Pennsylvania in the early 1980s. The high-employment sample, shown in Panel B, has slightly higher average earnings and lower mortality rates, but otherwise looks similar to the broad sample in Panel A.

Our sample extends the original sample used by JLS by three years. Since we are particularly interested in the long-term effect of mass-layoffs, we replicated the main result of the earlier paper using the high attachment sample. The results are shown in Figure 1, which displays estimates of the percentage difference in annual earnings relative to the baseline period and to the comparison group of workers remaining at their employer in 1980 to 1986 controlling for year, age, and worker fixed effects. The estimates confirm the result in JLS that job displacements in the course of a masslayoff lead to large immediate effects and a pattern of incomplete reversion in the first five years after layoff. In addition, they show that there is no sign of catching up even eight to eleven years after a job loss. The long-run decline in earnings we estimate is on the order of $20 \%$.

We next analyze the effect of the same mass-layoff events on mortality. As a preliminary step, Table 2 shows various averages of raw and adjusted mortality rate by job loss status and their difference. These straightforward tabulations give a preview of our main results.

- First, we find an increase in average mortality rates from 1987-2002 for those losing jobs at mass-layoffs during the period from 1980-86 (Column 4). For the sample without work restriction, we find that the initial effect occurring during the layoff period is particularly large; the effect is stable for the remainder of the period (Panel B).

\footnotetext{
${ }^{29}$ We replicated estimates of the age-gradient in mortality in the appendix (Appendix Figure 1), and find it to be quite
} similar to the typical pattern for representative U.S. samples. 
- Second, these differences are robust to controls for age, prior earnings, and initial firm size (Column 6). Below we also show that they are also robust to adding industry and firm fixed effects, adding further controls, or pooling the samples of movers and stayers.

- Third, once we control for the changes in average earnings at job loss, the difference in mortality rates becomes small and insignificant (Column 7).

The comparison of average mortality rates suggest that job displacement can lead to substantial increases in mortality in the short and long run, and thereby significantly reduce job losers' overall life-expectancy. In what follows, we substantially deepen our analyses of these results.

To fully exploit the structure of our data, we estimated several logistic regression models for death in a year given survival until the previous year and include controls for age, year of the sample, and baseline career outcomes shown in equation (2). The first group of estimates, based on the broad sample with no employment restriction past 1979, is shown in the first column of Table 3. The entries in the table are parameter estimates on the MLF-dummy from separate logit models; parameter estimates for other covariates for our most extended model are shown in Table 4. Recall that since average mortality rates are small, these coefficients can be interpreted as approximate percentage changes.

The coefficient shown in the first column of Table 3 indicates that displacement between 1980 and 1986 is associated with an increase in the log odds of death each year of about 0.28. Because the probability of death each year is low, this implies about a $28 \%$ increase in the probability of dying each year given survival to the previous year. The inclusion of log average earnings and the log standard deviation of earnings in 1974-79 affected the estimate only marginally.

To further assess whether our estimates might overstate the effect of job loss on mortality because firms selectively fired the least healthy workers, rows (A) to (D) add additional characteristics of workers' careers from 1974 to 1979. Including dummies for 1-digit industry during the baseline reduces the coefficient slightly. While added career outcomes - such as time worked or the growth of earnings - are significantly correlated with long-term mortality (Table 4), and partly 
differ by job loss status (Table 1), their inclusion matters only slightly. In results not reported here, the same holds when we also add number of job changes or number of large earnings shocks. Similarly, interacting average quarterly earnings and the standard deviation with dummies for agecategories at baseline to allow for a more flexible specification does not affect our results (row D).

We interpret these results to mean that there are large and robust effects of job displacements on long-term mortality outcomes. In particular, our results are not affected by displacement workers being selected on pre-job loss career outcomes. The robustness to industry fixed effects also implies that our results are not driven by differences in the rate of downsizing and mortality (e.g., because of job safety) across industries.

The bottom panel of Table 3 re-estimates all specifications using fixed effects for the firm in 1979 instead of baseline industry. Due to the difficulty in estimating fixed effects in the logit model, we use a linear probability model. To make the estimates comparable, we also show the percentage effect relative to mean mortality in the sample. ${ }^{30}$ Including firm fixed effects, the estimates are typically the same or somewhat larger (although the difference is never statistically significant). This may be consistent with the fact that Pennsylvania experienced downsizing in some traditionally highwage sectors with large firms, such as steel manufacturing, and it appears that these firms also tended to employ healthier workers.

The second column of Table 3 shows the results when we use our high-attachment sample (the original JLS sample). The effects are somewhat smaller but still large and significant. As shown in column 4, the difference in the estimates arises primarily because the later start of the follow-up period for this sample excludes deaths occurring right after the job loss. In addition, by focusing on workers who continue to work for a certain number of years after a layoff the high-attachment sample is likely to exclude the frailest workers most likely to die as a result of a layoff. As for the broad sample, including industry or firm effects and the standard deviation of pre-job loss earnings

30 When we replicated the main results with a linear probability model, the estimates are very similar to the results in sTables 2 and 3 . 
reduces the effect of job loss on mortality by a bit less than a standard error. Again, including further career characteristics has hardly any bearing on the results.

Overall, for cohorts born after 1930, the effects range from $10 \%$ to $28 \%$ depending on the sample and follow up period. In particular, once the follow up period is limited to start in 1987, the estimates are of similar order of magnitude for alternative degrees of labor force attachment and range between $10 \%$ and $17 \%$. The right hand side of Table 3 shows estimates including workers born from 1920 to 1929, who would be on average 55 to 60 at layoff. Including older workers the effect of layoff on mortality is somewhat smaller, albeit still large and highly significant. These differences are further addressed in Tables 5 and 7.

Although the coefficients in Table 3 give an approximate effect of MLF on the hazard of death, the curvature of the logit-function implies that the true marginal effect varies by age and earnings. In Figure 3 we show differences in the fitted probabilities of dying due to mass-layoffs by age and average earnings at layoff. Since the probability of dying increases faster for older and poorer individuals, the effect of mass-layoff rises with age and declines with average earnings. As shown in Appendix Table 2, the percentage change relative to the baseline is similar across ageearnings cells, with exception of the youngest workers due to their low baseline hazards.

Table 5 breaks up the effect of job loss on death by year since layoff. This is shown graphically in Figure 2, which plots the point estimates and two standard error bands. For our main sample in columns 2 and 3, we see large percentage increases immediately after job displacement when the baseline hazard is low. The effect remains high for the first five years after job loss. However, the effect gradually declines with time since layoff and bottoms out at a long run average of about $15 \%$, a result more similar to the other estimates in Table 3 . These estimates suggest strong immediate responses to when the impact of a layoff on career outcomes is most severe. The effects then stabilize at a permanent difference as workers continue to suffer negative consequences of layoffs in terms of reduced earnings.

Columns 5 and 6 show the same estimates including the earlier cohorts. The effect of job loss on the long-term mortality rate is similar in the two samples. This is expected, because ten years 
after job loss the results in the second part of the table are again driven by a younger group of workers. However, the results indicate an important difference in the initial response to job loss when workers age 55 to 65 at job loss have most weight. Older workers' mortality appears to respond much less in the first five years after job loss than that of workers in middle age. This is perhaps not surprising, since workers in that age range are likely to have either access to Social Security Benefits at age 62 or to company pension plans. Even for workers not yet at retirement age, access to disability insurance improves substantially at age 55 , when workers can claim loss of vocational qualifications to qualify for disability insurance (e.g., Chan and Van der Klaauw 2005, Black, Daniel, and Sanders 2002). Middle aged workers do not have access to similar mechanisms to smooth long-term earnings losses.

One can see that in both samples the effect actually increases somewhat 15 years after job loss, amounting to a U-shape, albeit a weak one. ${ }^{31} \mathrm{~A}$ similar pattern has been observed for the event of losing a spouse that leads to an initial increase in mortality from stress, and a long-term rise of the mortality rate to the level of single individuals (e.g., Martikainen and Valkonen 1996). The pattern is suggestive of an initial response due to acute stress caused by the job loss, followed by a long-term impact of increased chronic stress due to lower earnings.

\subsection{Sensitivity Analysis: Selection and Misclassification}

We have shown that our estimates are very robust to the inclusion of an extensive set of alternative control variables and industry and firm fixed effects. We have argued that this suggests the remaining bias from selective displacement or from sorting of workers into firms is small, especially in an environment of Pennsylvania in the early to mid 1980s, when firms were either unionized or followed seniority rules in dismissals, and mass-layoffs were large. Both of these factors may have reduced the ability to selectively displace workers. Yet, as in any non-experimental study,

\footnotetext{
${ }^{31}$ Appendix Figure 1 explores the role of the time-pattern of the effects of job further. The upper panel shows the raw mortality rate by mass-layoff status over the period under study. The aging of the sample is apparent for both lines. In addition, it appears the difference in mortality rates is greater at the beginning and at the end of the sample period. To eliminate age and year effects, the lower panel of Appendix Figure 1 plots the coefficients of an interaction of a job loss dummy with annual dummies for years since 1987, the beginning of our follow up period.
} 
we cannot fully exclude that firms use information on workers' health development not captured by workers' earnings level, growth, or patterns of non-employment when deciding which workers to displace.

To address the question of a remaining bias from selective displacement directly, we present results obtained from estimates that pool movers and stayers. These estimates replicate the main specification shown in equation (2), but define the main variable of interest at the firm level, not the worker level. Since the mass-layoff dummy now varies only at the firm, not at the worker level, the estimates compare the mortality of all workers present at a firm experiencing a mass-layoff before and after the layoff with similar workers at stable firms. The resulting intent-to-treat estimates are not affected by selection at the time of job loss. However, they may still be affected by sorting of workers into firms prior to layoff. To control for any remaining bias from sorting, we also include industry fixed effects and our core career characteristics prior to layoff. ${ }^{32}$

The resulting estimates in Table 6 confirm our main findings. The top panel shows the results for mortality as an outcome, the bottom panel replicates the estimates for earnings. The table shows estimates for two sets of mass-layoff definitions. The first defines mass-layoff as in JLS and in our main estimates. Since this includes gradually declining firms, it makes less sense when working at the firm level. Thus, Table 6 also includes specifications where mass-layoff is defined as a sudden large drop in employment at the firm. We focus on the results based on this cleaner layoff definition (Columns 3 and 4). The estimates for the average effect on mortality during the period from 1980 or 1987 to 2002 in Panel A is imprecisely estimated once industry dummies are included. However, the magnitudes, when scaled by about a factor of three (the inverse of the effect of mass-layoff on

\footnotetext{
32 While the pooled estimates should be free of bias from selective job displacement, they may still be affected by a bias from sorting of less healthy workers into sectors or firms with higher displacement rates. In our main analysis, we showed that the results are unaffected by the inclusion of industry or firm fixed effects. Here, we cannot include firm fixed effects without losing precision, but the results are robust for inclusion of industry controls.
} 
mobility, which is about 0.3$),{ }^{33}$ are comparable to the main results, especially for the 1987-2002 period.

The dynamic estimates in Panel B (columns 3 and 4) show an increase in death rates in the two years prior to closure (parallel to the decline in earnings), as well as a large positive spike at mass-layoff. Rescaled by a factor of three, the magnitude of the increase is remarkably similar to the size of the effects shown in Table 5 (when the mass-layoff dummy was defined as an individual job loss at a firm experiencing a mass-layoff). The effect then drops in the years following the layoff and increase in the long run. The long run effect is again significant and of similar magnitude as for the main estimates that distinguish between movers and stayers. The results are similar but noisier in the case of the gradual mass layoff definition in columns (1) and (2). We see a spike at layoff and a positive long-run effect, but also a rise a mortality difference four years prior to layoff. This suggests that the timing of the shock affecting workers at the firm level is better captured by a sudden in employment. $^{34}$

The definition of mass-layoffs also makes a difference for the analysis of earnings shown in Panels C and D of Table 6. In particular, the sudden drop leads to sharper losses in earnings around the mass-layoff date and larger earnings losses in the first ten years after layoff. The effect of the definition of mass-layoff based on administrative earnings estimates on the cost of job loss in terms of earnings is discussed in detail in Hildreth, von Wachter, and Weber (2005).

These results confirm that our main estimates are unlikely to be driven by selection. The same conclusion is borne out when we split the sample by the size of layoff. The results in Appendix Table 3 suggest that at best, workers at firms with higher layoff rates have higher mortality (columns

\footnotetext{
33 If we estimate the same regression models with an individual dummy for the event of job displacement as dependent variable, the coefficient is 0.299 and 0.289 for the gradual and sudden drop definitions of mass-layoff, respectively. This number also results from the fraction displaced in Appendix Table 1.

34 This is less of a problem with job loss definition at the individual level used in our main estimates. There, the shock was an individual job change from a firm experiencing strong gradual decline in employment as in JLS. When the main shock is defined at the firm level, the gradual nature of the decline leads some workers to be affected prior to the date at which we assign them the mass-layoff. This is confirmed by the results based on a sudden drop in employment.
} 
4 to 6$).{ }^{35}$ The table also shows that other separators (those leaving their employers but not during a mass-layoff) do not have higher mortality rates (column 3). Consistent with results in Tables 3 and 6, these numbers imply that selection into job loss appears not to be a pervasive problem in our application.

Finally, note that the fact that the estimate of the effect at the time of layoff in Table 6 (properly rescaled) coincides with that in Table 5 suggests that the initial spike we find is not driven by a mechanic misclassification of dying stayers as job movers. This confirms the prediction of the bias calculations discussed in section 3. This does not imply that there is no misclassification just that it is unlikely to play an important role in determining our results.

\subsection{Mass-Layoff Effects on Mortality by Age and Industry}

Given the role of age at layoff apparent in Tables 3 and 5, Table 7 shows the results for specifications allowing a more flexible impact of mass-layoffs by age at job loss. To cover a broader age range, these models are estimated only including the earlier cohorts. Clearly, the largest effect of MLF on mortality is for younger and middle-aged workers. The lowest effect is for workers age 60 and above, the difference being largest for the broad sample. This is consistent with the fact that younger workers experience the negative consequences of mass-layoffs on their careers for much longer periods of time. Being laid off before retirement appears to have no health consequences. This will make an important difference when calculating the effects on life expectancy below.

Table 7 also shows the results by industry, mean earnings prior to job loss, and region. To maximize sample size, we again show the results for workers born after 1920. The effects are among the highest in steel and other durable goods manufacturing. This is to be expected, since there are sectors with traditionally high paying jobs that were over-represented in Pennsylvania and experienced large reductions in economic activity. However, the effects of job loss at mass-layoff are also large in construction and transportation, and in services.

\footnotetext{
35 This result, robust to controls for age, average earnings, and other pre-job loss outcomes, is consistent with the hypothesis that smaller firms are more likely to close and provide less favorable career environments and possibly attract less able workers.
} 
When we break up the sample by quartile of average earnings in 1974-79, the results differ somewhat across samples. When we require no or some work attachment during the layoff-period, the effect is lower for those from the highest quartile of the pre-layoff distribution; when we consider the sample with high work attachment, the effect is reversed. This may indicate that the high attachment sample excludes low earners with unstable work attachment and higher mortality. The bottom of the table also shows that the effects tend to be larger in eastern Pennsylvania. This is perhaps somewhat surprising, since most of the steel manufacturing and heavy industry is in the western part of the state. However, we also see strong effects of job displacement on mortality in transportation, construction, and services, sectors relatively more important in eastern Pennsylvania.

\subsection{The Reduction in Life-Expectancy due to Job Loss}

Since increased mortality affects workers over a long time horizon, our estimates imply substantial reductions in life expectancy. The average loss in life-expectancy can also be used as a summary measure of the cost of job loss at mass-layoff in terms of life-years, much as the present discounted value of life-time earnings losses provide summary measures in conventional analyses of the cost of job loss. In Table 8, we present a range of estimates of losses in life expectancies for alternative samples and ages. Since some cohorts are still alive at the end of the sample period, to calculate the total cumulated effect of permanently greater mortality hazards we have to make an assumption about the development of mortality differences among laid off workers and the control group past our observation window. Specifically, we maintain the assumption of constant proportional differences in the odds of death. Given that the typical profile of the log odds of dying is stable through older age ranges, and is so within the groups of our sample, this is a plausible assumption. To take into account that the effect of mass-layoff on mortality differs by age at displacement, the losses in life expectancy in Table 8 are based on estimates in Table 7. All life- 
expectancies are calculated for workers with average annual earnings in 1974-79 and working in the steel industry in $1979 .{ }^{36}$

The first set of estimates shows the loss in life expectancy for our most general sample. Since there are large spikes in mortality at layoff, for this sample we also take into account the dynamic response in mortality estimated in Table 5. The last column shows large losses in life expectancy of more than two years for workers losing their job in their 30s and 40s. Life-expectancy of workers displaced in their 50s still declines, but about half as much. This difference arises first, because younger workers are exposed to higher mortality rates over a longer period of time. Second, because the increase in mortality rates are greater for younger workers, possibly because earnings losses accrue over a longer period of time.

The remaining sets of estimates show results for samples restricting workers to have some employment in the period of job loss. Since for these samples follow up starts in 1987, we first replicate the calculation for our broad sample using the shorter follow up period. The results show smaller losses, since we take out the initial period with strong mortality effects and reduce the range of time over which losses can accrue. The next two sets of estimates are for a sample requiring three year employment, and the JLS sample requiring some work every year from 1980 to 1986. The estimates decline further but remain in the range of one to one and a half years in particular for younger and middle aged workers.

Given these substantial declines in life expectancy, an important question is how these losses should be treated with respect to more conventional estimates of the cost of job loss. The typical measure of the cost of displacements is based on the loss in present discounted value of earnings. For the average worker in our high attachment sample this amounts to about $\$ 200,000$ at a real interest rate of four percent. To make the losses in life expectancy comparable, we can monetize them by choosing an estimate of the statistical value of life. At about five million dollars per statistical life, a loss in one and a half years would amount to a monetary loss of $\$ 100,000$. Although

\footnotetext{
${ }^{36}$ Life expectancy can be calculated as the sum of survivor probabilities over the remaining age-years an individual is alive. The difference in life-expectancies then is the sum of the differences in survivor probabilities.
} 
they can be no more than broadly indicative, values of this order of magnitude implies that the willingness to pay of a worker to avoid a job loss may be substantially underestimated by traditional summary measures such as the loss in life-time earnings. ${ }^{37}$

\section{Potential Channels of Mass-Layoff Effect on Death}

The most frequently studied consequence of job displacement is the long-term decline in earnings. The long-term earnings decline observed in Figure 1 is a likely channel through which layoffs raise mortality in the long run. Lower earnings may affect necessary health investments or lead to unhealthy life styles. Alternatively, it may raise mortality by increasing social stress. However, layoff can affect other career outcomes such as variability of earnings, job changes, or regional mobility. Such adjustments are likely to be closely correlated with the earnings loss. They may also directly affect mortality by increasing stress from adjustment, loss in familiar environments, or put strain on social relationships. A common difficulty in accounting for the role of each separate channel is that workers' responses to a job loss may be itself correlated with their underlying health status. An added difficulty is that very little is known about the correlation of permanent earnings and other long-term career outcomes with mortality. Similarly, remarkably little systematic and representative evidence exists about the effect of mass-layoff on outcomes other than earnings.

Despite the difficulty of the problem, the exceptional nature of our data allows us to gain important insights on the potential role of alternative channels not possible with existing sources of information. First, we can gauge the potential magnitude of the sources of the mortality effect we find by providing new the first estimates of the association of long-term career outcomes with death

\footnotetext{
37 To think about how these two numbers should be treated, consider that in the typical neo-classical model of health investments in which long-term health is an outcome of optimally chosen inputs given a life-time budget constraint. In this case, the loss in the PDV of earnings is a sufficient statistic for the cost of job loss, since the reduction of life time would be the optimal response to the reduced resources. However, only a small fraction of health expenditures are out of pocket. Moreover, health is likely to be affected by factors other than consumption or health inputs. For example, it may be affected by losses in social status related to earnings declines at layoff. In that case, the PDV of earnings losses is not a sufficient statistic anymore, and to obtain the total costs of job displacements the monetary value of the direct effect of layoffs on mortality should be added to the PDV of earnings losses. In particular, we should have that the Total cost of job loss $=$ PDV of Earnings Losses $+a \times$ Monetary Value of Lost Life, where $a$ is between zero and one. In the neoclassical model, $a=0$; in a model of social status, $a=1$. The right value probably lies in between, but given the limited role of individual health expenditures it is likely to be closer to one than to zero. This implies that increases in mortality due to layoffs substantially raise the costs of job loss and workers' willingness to pay to avoid displacement.
} 
and job loss. Second, we directly estimate the effect of earnings losses and changes in other outcomes on the effect of job loss on mortality. Third, we address the fact that earnings losses may be correlated with underlying health status by exploiting predictable variation in earnings loss at cell level. Using this strategy, we obtain four results:

- First, while all career outcomes are likely to have some impact in the short run, the predicted effect of earnings is largest and the only effect lasting more than five years after mass-layoff; in the individual level models, earnings changes can explain the entire mass-layoff effect on mortality.

- Second, it does not appear job losers' earnings changes are more strongly correlated with mortality than that of stayers, suggesting that the effect of earnings losses at job displacement on mortality is not primarily due to ill health of job losers.

- Third, the potential role of earnings changes is confirmed when we exploit variation in predictable earnings losses by groups of age, industry, or region groups.

- Fourth, those groups of workers with the highest loss in present discounted value of lifetime earnings are those with the largest losses in life-expectancy.

Overall, we interpret these results as suggesting that at least for job losses involving such dramatic earnings declines as in Pennsylvania in the early to mid 1980s, the sources of the increase in mortality are likely to be strongly correlated with earnings losses. This may include direct effects of earnings, but also stress and adjustment costs correlated with long-term earnings declines. Clearly, although suggestive, our results do not exclude the possibility that earnings losses and mortality increases may also be driven by a common underlying variable such as depression as a result from job loss.

\subsection{Long-Term Career Outcomes and Mortality}

To help us gauge the magnitude of the effect of potential channels, we exploit the longitudinal nature of our data to provide estimates of the correlation of career outcomes in the baseline period with mortality in the follow up period. Table 4 shows the estimates from our most 
complete model for the various alternative samples, with more detail contained in Appendix Table 6. Although these estimates of career outcomes on long-term mortality are of substantial independent interest, we limit ourselves to summarizing the main points. The Appendix discusses the results in more detail. First, average earnings have a large and robust effect on long-term mortality; only average earnings matter in the long run, not earnings in any given year. The effect we estimate is about a third larger than typical estimates in the literature, and we show that this is due both to classical measurement error from the use of earnings from survey data as well as measurement error from approximating permanent earnings by current earnings.

Second, the standard deviation of log quarterly earnings in 1974 to 1979 has robust and sizeable effects the long term mortality rate. ${ }^{38}$ Figure 4 suggests that the correlations for both measures are well captured by a log-specification. These results suggest workers with lower average earnings and higher earnings variability die younger. Of course, while reverse causality and measurement error are less of a concern here, omitted variable bias still is. Last, other career measures we tried have little discernible effect on long-term mortality outcomes. The exception is time worked which enters significantly negatively for some samples, consistent with Ruhm's (2002) analysis of the effects of recession on mortality.

\subsection{Effects of Mass Layoffs on Career Outcomes}

To better understand how displacement impacts mortality, we also studied the impact of displacement on a broad range of workers' career outcomes. As noted above, our estimates are based on an annual distributed lag model that controls for worker fixed effects, year effects, and a quadratic in age. Because in our Pennsylvania administrative data earnings may appear to be zero when workers have moved out of state, we focus on a sample of workers who had positive earnings in every year through 1991.

As Table 9 shows, we estimate that displacement some time during the 1980-1986 time period reduces workers' earnings by approximately 22\% in the 1987 to 1991 period. These estimates

\footnotetext{
38 We use the standard deviation of the log of quarterly earnings to obtain a measure of earnings variability based on percentage changes that is comparable across wage levels.
} 
are quite similar to those reported in Jacobson, Lalonde, and Sullivan (1993) for a somewhat shorter follow up period. Thus the earnings losses associated with job displacement for workers with substantial job tenure appear to be extremely persistent.

Table 9 also shows that many other career outcomes are strongly affected by a layoff in the short run but return to normal at about the fifth year after a job loss. In particular, we find strong temporary increases in absolute value of earnings growth (our measure of annual career variability) and job and regional mobility. These results suggest that after an initial turbulent phase, job losers settle into a stable career at a permanently lower level of earnings.

\subsection{Gauging the Effects of Alternative Channels}

Using the results in Table 9, one can gauge the potential order of magnitude of different channels through which mass-layoffs can affect mortality. To do so, we combine the mass-layoff results with the correlations shown in Table 4. Clearly, this does not yield a true decomposition of the effect as if these were causal parameters. Below, we will try to gauge our interpretation using predictable differences in earnings losses across groups of workers.

The two main career outcomes that were most important in our analysis of correlations are mean and standard deviation of log quarterly earnings. Taken at face value, the estimated correlation of average earnings with mortality of -0.5 would imply that we expect an increase in mortality of about $12.5 \%$ for workers with high attachment $(0.25 * 0.5)$. Thus about two-thirds of the long-run effect of mass-layoff on mortality, about 0.15 to 0.2 , could be explained by the observed declines in average earnings. Clearly, if frail workers die younger and have lower average earnings, this prediction overstates the potential effect of job loss through earnings. ${ }^{39}$

\footnotetext{
39 In his study of Swedish lottery winners, Lindahl (2005, Appendix Table 2) shows that the effect of controlling for initial health conditions tends to reduce the correlation between mortality and earnings by about a third. (The magnitudes of the OLS effect that Lindahl estimates are somewhat smaller but in the same ball-park as ours. He does not report logit estimates, so the comparison is based on approximate percentage effects derived from the results of linear probability models.) Were this to be the case, the predicted role of earnings in explaining the mass layoff effects is reduced to about half of the effect, which is still substantial. Note however that our high-attachment sample is likely to be of better health than the older sample used in Lindahl (2005).
} 
The remaining effects could partially be driven by increases in the instability of earnings and other career outcomes. From a replication of Table 8 in with a difference-in-difference specification, we find the standard deviation of log quarterly earnings increases on average by about $16 \%$ at a mass-layoff. At a coefficient of - 0.2 (Table 7), this implies an increase in the probability of dying of about $3.2 \%$. While the order of magnitude of this effect is much lower than the potential impact of earnings, it can still account for about $20 \%$ of the mass-layoff effect. Although the fact that they also attain for workers with high job attachment and are robust to controls for baseline average income lends credibility to the results, if frail people have higher earnings instability and higher death rates, this prediction is likely to be over stated. Moreover, as shown in Table 8, this effect is relevant mostly in the short term and is unlikely to be able to explain persistent increases in mortality rates.

These straightforward calibrations suggest a potentially important role for long term earnings losses in explaining the effect of layoff on mortality we find. To further explore the role of longterm earnings losses in accounting for the effect of job displacement on mortality, we also directly included the long-term earnings change into our logit model (equation 3). The result is shown in the first panel of Table 9 for alternative samples. The results suggest a strong correlation between earnings changes and long term mortality. Moreover, once we condition on earnings changes, the effect of the mass-layoff dummy becomes numerically small and insignificant. Figure 5 confirms these patterns by showing the non-parametric relationship between long-term earnings losses and mortality, controlling for age, year, and past average earnings.

These results further suggest that the mechanism explaining the mass-layoff effect on mortality strongly correlates with long-term earnings losses. However, as discussed in Section 3, we cannot interpret these results as indicating a causal channel from earnings losses to mortality, unless we are willing to assume that the earnings response to layoff is not correlated with workers' health. Note that if there were a strong correlation, then we would expect the correlation of earnings losses and mortality to rise for workers experiencing a job displacement. However, if we replicate our estimates focusing on the sample of job losers, the coefficients on the earnings change becomes smaller (row two of Table 9). 
To further examine whether earnings losses really capture the effect of increasing stress in the labor market due to uncertainty, we also included the standard deviation of quarterly earnings from 1987 to 1991 (not shown). If earnings losses just index the degree of stress due to adjustments in the labor market, we might expect that this would reduce the effect of earnings changes on mortality. However, although as expected the standard deviation has a positive significant effect, the impact of earnings changes on long-term mortality outcomes is unaffected.

The results in this section are suggestive of an important role of earnings losses in explaining the effect of layoffs on mortality. However, here may be omitted variables that drive both earnings losses and mortality increases, such as a differential increases in depression in response to layoffs. To explore the role of earnings losses further, we next try to exploit cell-level variation in earnings losses.

\subsection{Cell-Level Analysis}

A long literature suggests that there are differential effects of job loss in the population (e.g., Farber 2003, JLS 1993, Kletzer 1989, Neal 1995). Part of these differences arise from differences in rent workers receive on the job that are permanently lost as workers move employers (von Wachter and Bender 2007). We would like to isolate groups of workers that have different rents and thereby predictable differences in earnings losses. If these groups do not have other differential responses to layoffs, we can study the effect of earnings changes at job loss on long-term mortality at the group level.

We use various cell definitions based on age, average earnings, industry, and region, all measured at the end of our baseline period. Wage differences among age and average earnings groups partially reflect differences in skills. However, they also reflect differences in wage levels due to contractual premiums (Beaudry and DiNardo 1991, Oreopoulos, von Wachter, and Heisz 2006), job search (Topel and Ward 1992), and firm and industry wage premiums (e.g., Krueger and Summers 1988, Abowd, Creecy, and Kramarz 2002). Similarly, differences in age lead to differential cumulated long-term earnings losses due to layoffs. Thus, differences in earnings losses among cells 
partly arise from labor market factors unrelated to productivity and health. Clearly, health responses to layoff may also differ across cells.

To implement our approach we regress mortality increases on average earnings losses at the cell-level. As explained in Section 3, this is equivalent to using cell-level dummies as instruments for earnings losses in a linear probability model of mortality. The lower panel of Table 10 shows the coefficient estimates on actual earnings changes in a linear probability model and the slope coefficient in the cell level model. The model also controls for cell-level dummies. Thus, the variation of earnings changes at the cell-level arises from the interaction of cell-dummies with the mass-layoff dummy. ${ }^{40}$

We find that the effect of earnings losses on mortality is similar at the individual and cell level for the samples with no or low work requirement. The cell-level effect is smaller for the highattachment sample, but standard errors increase substantially as well. ${ }^{41}$ As before, if we include the mass-layoff dummy, its coefficient is small and insignificant. However, now the estimates lose precision. The bottom panel in Figure 5 shows the corresponding cells and a linear regression line for the high attachment sample. There is a clear negative and relatively precise association, albeit there is a high degree of variation left. The results are very similar for different definition of cells. Unfortunately, we could not include changes in the standard deviation at the cell level without further losing precision.

The resulting value for the mean-squared error of the group-level regression is the test statistics for of a test of over-identification with a limiting Chi-Squared distribution with degrees of freedom equal to the number of cells. This test is equivalent to the standard test of overidentification in 2SLS and amounts to a joint test of the equality of the different Wald-estimates corresponding to each group (Angrist 1991). In results not reported here, for neither model can we

\footnotetext{
40 The cell-level model is implemented in two steps. First, we regressed individual earnings and mortality on characteristics such as baseline earnings, baseline standard deviation, a quartic in age, and year effects; in addition, we included cell-level dummies, and interactions between cell-level dummies and the mass-layoff dummy. The coefficients on the interaction are used in the second step. Second, we regress cell-level changes in mortality on cell level earnings losses weighting by the inverse sampling variance of the cell-specific mortality increases.

${ }^{41}$ Note that the standard errors are from the group-level model and are thus corrected for group-level error components.
} 
reject the over-identifying restrictions at any reasonable degree of significance. This is particularly helpful in our case, since failure to reject the null-hypothesis supports an underlying model of a constant proportional effect of earnings on mortality.

Although the results discussed so far refer to changes in average earnings, standard models of health investment refer to life-time resources as the relevant earnings concept. That this could make an important difference is suggested in Table 7. Although older workers typically have the largest losses in earnings (e.g., Farber 1997, JLS 1993), they experience the lowest increase in average mortality rates after a job loss. This may be because older workers are typically exposed to reduced earnings for a shorter period of time.

To address this question, we calculated the present-discounted value (PDV) of life-time earnings losses following a job loss at a mass-layoff by age-group. ${ }^{42}$ The results, shown in Figure 6, show that the PDV of earnings losses after a job loss is a declining function of age. The figure also displays losses in life-expectancy taken from Table 8 by age-group. Young workers not only have higher average mortality increases after a job loss (Table 7), but also the largest life-time losses in earnings and remaining life-time. Thus, it is not the oldest workers that are most affected, but those in prime working age that are exposed to the negative consequences of job loss over a longer period of time.

Given the robustness of our results across specifications, and the similarity of results at the individual level and cell level, we interpret the foregoing analysis as confirming an important channel for earnings changes on mortality. Clearly there are other explanations consistent with our results. For example, changes in depression or stress at the group level may lead to both greater earnings losses and larger increases in mortality. In either case, our results suggest that any channel explaining the effect of job displacement at mass-layoffs on mortality is likely to be at least correlated with the degree of earnings losses.

\footnotetext{
${ }^{42}$ To do so, we allowed the short- and long-term effects of job loss on earnings to vary by either 10 year or 5 year agegroups. Since we do not have complete earnings histories after job loss for all workers, we assume that the earnings loss decays at the same speed of reversion observed between years 6 to 11 after a job loss eventually staying fixed at zero.
} 
As discussed in Section 2, our results are not in conflict with recent studies suggesting that mortality declines in recessions (e.g., Ruhm 2000), since the shock we analyze is of different nature than the impact of aggregate variation in economic activity. In addition, the role of employment in our regressions suggests that stress and work-accidents may play an important role in our sample as well. Some non-employment in the years prior to job loss turns out to reduce mortality in the long run (Table 4); conditional on earnings losses, job losers with some non-employment live longer on average (Appendix Table 4); similarly, conditional on earnings losses, those job losers with largest earnings increases have higher mortality as well.

Thus, while the strong earnings losses play a particularly important role in our sample of job losers in the recessions of the early 1980s in Pennsylvania, this does not exclude the influence of other channels. In particular, it does not preclude the dominance of other channels in situations where earnings losses are not as large and sustained as in our case.

\section{Conclusion}

This paper uses administrative data covering over 15 years of quarterly earnings and employer records matched to information on date of death to study the effects of job displacement on mortality. To measure an event plausibly exogenous to workers' own health outcomes, we analyze job losses occurring when employers experience mass layoffs affecting at least 30\% of their work force. To further control for selection, we also control for workers' average earnings and a range of career outcomes in the period before job loss, and present selection-free estimates pooling movers and stayers. The results suggest a particularly pronounced increase in mortality during the period immediately following job loss and long-run increase of $15-20 \%$ in the annual probability of dying persisting for at least the next 20 years. These effects, robust across alternative samples and specifications, are consistent with strong responses to both acute and chronic stress.

To analyze the channels underlying the mass-layoff effect we analyze the correlation of longrun career outcomes with mortality. We show that the mean and standard deviation of earnings during a baseline period have large and significant correlations with mortality in a later follow up 
period. The results on the role of earnings and employment instability are novel with respect to the existing literature on mortality that has had not access to long-run career outcomes. Together with estimates of the effects of mass-layoffs on long-run career outcomes these results suggest that an important fraction of the effect of job loss on mortality can be attributed to persistent losses in earnings. This is confirmed by a direct analysis of differences in mortality responses by groups of workers with differential earnings losses at job displacement.

These results suggest that events in the labor market shaping workers' careers also have long-run effects on health outcomes. The losses in life expectancy implied by our results shows these effects can be large. A worker displaced in mid-career can expect to live about two years less than a luckier counterpart. The reduction in life expectancy is smaller for older workers who experience lower life-time earnings losses and are exposed to increased mortality for a shorter period of time. Our results do not speak to the role of non-economic factors such as stress, self-worth, and happiness. Yet, they suggest an important avenue for future research would be to examine whether the negative health consequences of mass-layoffs can be prevented by providing assistance that stabilizes the level and variance of earnings. 


\section{References}

Aaronson, Daniel and Daniel Sullivan (1998). 'The decline of job security in the 1990s:

Displacement, anxiety, and their effect on wages.' Federal Reserve Bank of Chicago Economic Perspectives, Vol.22 No. 1.

Abowd, John, Robert Creecy, and Francis Kramarz (2002). 'Computing Person and Firm Effects Using Linked Longitudinal Employer-Employee Data.' Cornell, mimeo.

Abraham, Katharine G. and James L. Medoff (1984). 'Length of Service and Layoffs in Union and Nonunion Work Groups.’ Industrial Labor Relations Review, Vol.38 No.1 pp. 87-97.

Angrist, Joshua (1991). 'Grouped Data Estimation and Testing in Simple Labor Supply Models,' Journal of Econometrics 47, February/March 1991.

Baker, George, Michael Gibbs, and Bengt Holmstrom (1994). 'The Internal Economics of the Firm: Evidence from Personnel Data.' Quarterly Journal of Economics 109: 881-919.

Beaudry, Paul and John DiNardo (1991). 'The Effect of Implicit Contracts on the Movements of Wages over the Business Cycle' Journal of Political Economy, 99(4).

Black, Dan, Kermit Daniel, and Seth Sanders (2002). 'The Impact of Economic Conditions on Participation in Disability Programs: Evidence from the Coal Boom and Bust,' American Economic Review, vol. 92(1), pages 27-50, March.

Bound, John and Alan B. Krueger (1991). The Extent of Measurement Error in Longitudinal Earnings Data: Do Two Wrongs Make a Right?' Journal of Labor Economics, Vol. 9, No. 1 pp. $1-24$

Browning, Martin and T.F. Crossley (2001). 'Unemployment Insurance Levels and Consumption Changes.' Journal of Public Economics. 80(1):1-23

Browning, Martin, Anne Moller Dano, and Eskil Heinesen (2006). 'Job displacement and stressrelated health outcomes.' Health Economics, Vo.15 pp. 1061 - 1075.

Burgard, Sarah, Jennie Brand, and James House (2005). 'Causation and Selection in the Relationship of Job Loss to Health in the United States.' Mimeo. University of Michigan.

Chan, Sewin and Ann Huff Stevens (2001) "Job Loss and Employment Patterns of Older Workers," Journal of Labor Economics 19, 484-521.

Chen, Susan and Wilbert Van der Klaauw (2006). 'The Effect of Disability Insurance on Labor Supply of Older Individuals in the 1990s' forthcoming in Journal of Econometrics.

Couch, Kenneth (2006). 'The Earnings Impact of Job Displacement Measured with Longitudinally Matched Individual and Firm Data.' Presented at 2006 SOLE Meetings.

Darity, William and Arthur Goldsmith (1996). 'Social Psychology, Unemployment, and Macroeconomics.' Journal of Economic Perspectives 10(1): 121-140.

Card, David, Raj Chetty, and Andrea Weber (2006). 'Cash-on-Hand and Competing Models of Intertemporal Behavior: New Evidence from the Labor Market.' NBER Working Paper No. 12639.

Deaton, Angus (1999). 'Inequalities in income and inequalities in health.' Research Program in Development Studies, Princeton University, mimeo. 
Deaton, Angus and Christina Paxson (1999). 'Mortality, education, income and inequality among American cohorts.' NBER Working Papers No. 7140.

Deaton, Angus, David Cutler, and Adriana Lleras-Muney (2006). 'The Determinants of Mortality.' Journal of Economic Perspectives 20(3): 97-120.

Efron, Bradley (1988). 'Logistic Regression, Survival Analysis, and the Kaplan-Meier Survival Curve.' Journal of the American Statistical Association 83 (402): 414-425.

Eliason, Marcus and Donald Storrie (2004). 'Does job loss shorten life?' Göteborg University Department of Economics Working Paper Series No. 153.

Eliason, Marcus and Donald Storrie (2006). 'Latent or Lasting Scars: Swedish evidence on the longterm effects of job displacement.' Journal of Labor Economics, 24, pp 831-856.

Evans, William N. and Steven Snyder, "The Impact of Income on Mortality: Evidence from the Social Security Notch,” NBER working paper number 9197, Review of Economics and Statistics, Forthcoming.

Farber, Henry (2003). 'Job Loss in the United States, 1981-2001.’ IRS Working Paper No. 471 Princeton University.

Farber, Henry (2007). 'Job Loss and the Decline in Job Security in the United States.' Industrial Relations Section Working Paper 520.

Gallo, W.T., H.M. Teng, T.A. Falba, S.V. Kasl, H.M. Krumholz, E.H. Bradley (2006). 'The Impact of a Late-Career Job Loss on Myocardial Infarction and Stroke: a 10-year Follow-Up Using the Health and Retirement Study.' Occupational and Environmental Medicine. July.

Gibbons, Robert and Lawrence Katz (1991). 'Layoffs and Lemons.' Journal of Labor Economics 9(4): 351-380.

Gottschalk, Peter and Robert Moffitt (1994). 'Growth in Earnings Instability in the U.S. Labor Market.' Brookings Papers on Economic Activity.

Gottschalk, Peter and Robert Moffitt (2002). 'Trends in the Transitory Variance of Earnings in the U.S.' The Economic Journal, Vol. 112 (478), C68-C73.

Gruber, Jonathan (1997). 'The consumption smoothing benefit of unemployment insurance.' American Economic Review 87 (1): 192-205.

Gruber, Jonathan, and Brigitte C. Madrian (2002) "Health Insurance, Labor Supply, and Job Mobility: A Critical Review of the Literature,” NBER Working Paper No. 8817.

Haider, Steven J. and Solon, Gary, "Life-Cycle Variation in the Association between Current and Lifetime Earnings" (January 2006). NBER Working Paper No. W11943

Hildreth, Andrew, Till von Wachter, and Elizabeth Weber (2005). 'Estimating the 'True' Cost of Job Loss: Evidence Using Matched Data from California 1991-2000.’ Mimeo, Columbia University.

Hines, James, Hilary Hoynes, and Alan Krueger (2002). 'Another Look at Whether a Rising Tide Lifts All Boats.' in Alan Krueger and Robert Solow. (Eds.), The Roaring Nineties: Can Full Employment Be Sustained? Russell Sage Foundation: New York.

Hill, Mark E. and Ira Rosenwaike (2002). 'The Social Security Administration's Death Master File: the completeness of death reporting at older ages.' Social Security Bulletin Vol.64 No.1. 
Jacobson, Louis, Robert LaLonde and Daniel Sullivan (1993). 'Earnings Losses of Displaced Workers.' American Economic Review 83(4): 685-709.

Kahn, Lisa (2005). 'The Long-Term Labor Market Consequences of Graduating College in a Bad Economy.' Harvard University. Mimeo.

Johnson, Norman, Paul Sorlie, and Eric Backlund (1998). 'The Impact of Specific Occupation on Mortality in the U.S. National Longitudinal Mortality Study.' Demography 36(3): 355-67.

Kletzer, Lori (1989). 'Returns to Seniority after a Permanent Job Loss.' American Economic Review 79: 536-43.

Krashinsky, Harry (2002). 'Evidence on Adverse Selection and Establishment Size In the Labor Market.' Industrial and Labor Relations Review 56(1): 84-96.

Krueger, Alan and Lawrence Summers (1988). 'Efficiency Wages and the Inter-Industry Wage Structure.’ Econometrica 56 (2): 259-293.

Lemieux, Thomas, Bentley MacLeod, Daniel Parent (2006). 'Employment and Bonus Pay in the U.S.' Working Paper.

Lindahl, Mikael (2005). 'Estimating the Effect of Income on Health and Mortality using Lottery Prizes as an Exogenous Source of Variation in Income.' Forthcoming, Journal of Human Resources.

Martikainen, Pekka and Tapani Valkonen (1996). 'Mortaltiy after death of a spouse in relation to duration of bereavement in Finland.' Journal of Epidemiology and Community Health, 50: 264-268.

Martikainen, Pekka, Netta Maki, and Markus Jantti (2007). 'The Effects of Unemployment on Mortality following Workplace Downsizing and Workplace Closure: A Register-based Follow-up Study of Finnish Men and Women during Economic Boom and Recession.' American Journal of Epidemiology Vol. 165 No. 9 pp. 1070 - 1075.

Miller, Doug and Christina Paxson (2006). 'Relative Income, Race, and Mortality.' Forthcoming, Journal of Health Economics.

Neal, Derek (1995). 'Industry-Specific Human Capital: Evidence From Displaced Workers,' Journal of Labor Economics, October, vol. 13: 653-77.

Ohlsson, Henry and Donald Storrie (2007). 'Long term effects of public policy for displaced workers in Sweden - shipyard workers in the West and miners in the North.' Uppsala University Department of Economics Working Paper Series No 2007:19.

Okun, Arthur M. (1973). 'Upward Mobility in a High-Pressure Economy.' Brookings Papers of Economic Activity, 1: 207-52.

Olson, Craig (1992). 'The Impact of Permanent Job Loss on Health Insurance Benefits.' Industrial Relations Section Working Paper No. 305. Princeton University.

Oreopoulos, Philip, Till von Wachter, and Andrew Heisz (2006). The Short- and Long-Term Career Effects of Graduating in a Recession: Hysteresis and Heterogeneity in the Market for College Graduates.' Mimeo Columbia University.

Paul Oyer, 2006. "The Making of an Investment Banker: Macroeconomic Shocks, Career Choice, and Lifetime Income," NBER Working Papers 12059 
Price, Richard, Jin Nam Choi, and Amiram Vinokur (2002). 'Links in the Chain of Adversity Following Job Loss: How Financial Strain and Loss of Personal Control Lead to Depression, Impaired Functioning, and Poor Health.' Journal of Occupational Health Psychology 7(4): 302-312.

Ruhm, Christopher (1991). 'Are Workers Permanently Scarred by Job Displacements?' American Economic Review 81: 319-23.

Ruhm, Christopher (2000). „Are Recessions Good for Your Health?” Quarterly Journal of Economics 115 (2): 617-650.

Schoeni, Robert and Michael Dardia (2003). "Estimates of Earnings Losses of Displaced Workers Using California Administrative Data." PSC Research Report No. 03-543.

Smith, James (1999). 'Healthy Bodies and Thick Wallets: The Dual Relation Between Health and Economic Status.' Journal of Economic Perspectives 13(2):145-166.

Smith, James P. (2003). 'Consequences and Predictors of New Health Events.' NBER Working Paper No. 10063.

Stevens, Ann Huff (1997). 'Persistent Effects of Job Displacement: The Importance of Multiple Job Losses.' Journal of Labor Economics, Vol. 15, No. 1, Part 1, pp. 165-188

Stevens, Ann Huff (2001). 'Changes in Earnings Instability and Job Loss.' Industrial and Labor Relations Review, Vol. 55, No. 1, 60-78.

Topel, Robert and Michael Ward (1992). 'Job Mobility and the Careers of Young Men.' Quarterly Journal of Economics 107(2): 439-479.

von Wachter, Till and Stefan Bender (2006) 'At the Right Place at the Wrong Time: The Role of Firms and Luck in Young Workers' Careers.' American Economic Review.

von Wachter, Till (2007). 'Summary of the Literature on Job Displacement in the US and EU: What we know and what we would like to know.' Mimeo, Columbia University.

Weber-Handwerker, Elizabeth (2006). 'The Social-Security Notch, Mortality, and Cohort Variability: A Cautionary 'Tale.' Mimeo. University of California Berkeley. 


\section{Appendix 1: Average Earnings and Mortality}

This is one of the few studies of earnings and mortality that approximate permanent earnings with more than a single year of earnings data. Figure 4shows various estimates of the correlation of average quarterly earnings in the period of 1974-1979 on mortality in 1986-2002. Since the natural logarithm turns out to be a good approximation to the declining correlation of average earnings and mortality, all our econometric specifications include the log of average quarterly baseline earnings. ${ }^{43}$ The first three columns of Appendix Table 5 show various estimates of Model (1) for our main mass-layoff sample (without a mass-layoff dummy). ${ }^{44}$ The effect of log average earnings is about -0.5 for the group of workers with high job attachment in the baseline period. Given that the probability of death is very small, the coefficient approximately implies a $10 \%$ decrease in mortality for a $20 \%$ increase in average quarterly earnings. For example, a two standard deviation increase in average quarterly earnings would lead to about a $4 \%$ decline in mortality. To properly assess the magnitudes of the estimated effects, the second panel in Appendix Table 2 and Figure 3 show the predicted values of the probability of dying by age- and income-group based on the estimates shown in Appendix Table 5 ( $1^{\text {st }}$ column and $1^{\text {st }}$ row $)$. As expected, the earnings gradient rises with age - a comparison of differences in mortality rates at $25^{\text {th }}$ and $75^{\text {th }}$ earnings percentiles shows substantial differences across age-groups. Equivalently, the role of age decreases for high-income workers.

These results are robust for cohort controls, are similar across age groups, are unaffected by controls for other career measures such as quarters worked, and are not changed if the baseline period is extended to cover 13 instead of 6 years (1974-1986). Interestingly, the effect of income is significantly higher for workers who worked in manufacturing during the baseline period (see Appendix Table 6, Models 6 and 7). To replicate results in the existing literature, we also estimated models of 5 and 10 year follow-up (e.g., see Deaton and Paxson 1999). The results, shown in columns 4 to 9 in Appendix Table 5, essentially confirm our main estimates. ${ }^{45}$ These estimates are bigger in absolute terms than the effects estimated by Deaton and Paxson (1999, Table 5) using CPS

\footnotetext{
${ }^{43}$ For high and low earnings, a fourth order polynomial does a better job at approximating the 'non-parametric' dummyvariable estimates. We chose the more parsimonious specifications, but double-checked our results by including earnings-dummies. This is particularly important when non-linearities can matter, such as in the analysis of earnings ranks. The more fully non-parametric results in the lower panel of Figure 1 confirm that a smooth concave function is appropriate to capturing the relationship between earnings and mortality.

${ }^{44}$ Appendix Table 5 compares results across alternative samples, further discussed below.

${ }^{45}$ Changes in the fraction of older workers in our panel sample over time are likely to explain variation in the results across age groups for these models.
} 
earnings data matched to mortality information. Even when we follow the literature by using a single year of earnings at beginning of the follow up period (row 3 of Appendix Table 5), our estimates are slightly larger, albeit weaker than the effects of average earnings. As shown in Bound and Krueger (1991, Table 6), the reliability ratio for men at single employers is about .8 in the case of classical measurement error, and .95-1 for mean-reverting measurement error. Thus classical measurement error could explain part of the difference of using annual earnings measures from survey data (CPS) and annual earnings information from administrative data (row 3).

The interpretation of the difference between the estimates in row 1 and row 3 is only slightly more involved. Consider a typical model of current earnings $y_{i t}$ as a function of persistent $\left(\theta_{i t}\right)$ and transitory $\left(u_{i t}\right)$ components

$$
y_{i t}=\theta_{i t}+u_{i t}, \quad \text { where } \theta_{i t}=\theta_{i t-1}+v_{i t}, \quad u_{i t} \sim A R M A, \quad v_{i t} \sim W N .
$$

If both components affect health and longevity, when included as the sole explanatory variable current earnings captures the joint effect of the permanent and transitory earnings components. On the other hand, if only permanent earnings matter for long-term health outcomes, then current earnings is a noisy measure of permanent earnings. If so, then row 3 is downward biased by either classical (if $u_{i t}$ has short memory) or mean-reverting measurement error. Since we have measures of permanent earnings available in our data, we can check this directly by including them jointly into the model. If current earnings are simply a noisy measure of permanent earnings, its coefficient should drop to zero. This is shown in the last two rows of Appendix Table 5 (and Appendix Table 6 for other samples). In most cases, including a measure of average earnings indeed drives the effect of current earnings to zero. ${ }^{46}$ This suggests that other studies having at disposition only measures of annual earnings should scale their coefficients up by a factor taking into account measurement error from survey responses as well as from transitory earnings disturbances. In separate calculations, we show that the combined reliability ratio can be as low as 0.6.

The current results are obtained from workers with a stable job from 1974 to 1979 who either continue to hold that job through the end of 1986 or who leave their baseline job at the time of a mass layoff. In both cases workers are required to have positive earnings in each year from 1979 to 1986. To assess to what extent our results are driven by the focus on high-attachment workers, Appendix Table 6 replicates our main specifications for a series of different samples. The second

\footnotetext{
46 Since the relationship between permanent earnings and current earnings also differs by age, the measurement error might be more complicated (Haider and Solon 2006). This should be partially taken into account by the age controls included in our models.
} 
column shows results based on all workers who have a stable job in 1974 to 79 (i.e., with respect to column 1 it includes non-mass layoff job changers), and confirms the results from the mass-layoff sample for all specifications. The third column substantially weakens the restriction on labor force attachment by including all workers who where employed or received unemployment insurance at least half of the time in 1974-79. The effect of log average earnings is somewhat lower, but partly due to correlation with quarters worked, which has a negative coefficient. ${ }^{47}$ This somewhat surprising result is consistent with Ruhm (2000)'s analysis suggesting lower economic activity in recessions may be beneficial to health. However, it turns out that the beneficial effect of nonemployment is not a very robust feature of our data. ${ }^{48}$ The last two columns show the results for high and low attachment samples of older workers for whom we calculate average quarterly earnings with all quarters available from 1974 to 1986 (spanning the last 10 to 15 years of workers' earnings). The results confirm those in corresponding columns 2 and 3, and suggest that our main estimates are not driven by the choice of a particular time period or reference period within a workers' career as baseline.

\section{Appendix 2: Career Instability and Mortality}

In addition to average quarterly earnings, other career outcomes such as the degree of employment or earnings stability may also be related to health and mortality. We have considered alternative measures of career instability, including the standard deviation of log earnings, the number of quarters worked, the number of large declines in quarterly earnings (drops in earnings of more than two standard deviations), the number of transitions into non-employment, the number of job changes, and the number of long non-employment spells. Workers in the main mass-layoff sample experienced important variation in earnings over the baseline period, as shown by the standard deviation and the high fraction of workers with large drops in earnings. Although by construction this sample has very few transitions to non-employment or job changes, both earnings and employment instability become very relevant for the broader samples in the remaining

\footnotetext{
47 The fourth column shows the results for a very broad sample that includes all workers who were ever present in the UI system between 1974 and 1979. The effects of log average earnings are even lower for this sample. These results partly derive from the fact that the standard deviation of log average earnings is much higher in the broader samples (see Table 4); i.e., a two standard deviation increase in log average earnings is of much more similar magnitude across samples. This also hints at the fact that for the broader sample, on average fewer observations are used to calculate average quarterly earnings. Thus, part of the difference will be due to attenuation bias from classical measurement error, too. In addition, it may be that for low-income workers, average earnings are a worse approximation of the actual amount of resources due to greater importance of second earners, family ties, and government subsidy programs. 48 The effects of quarters worked are positive for the sample of older high-attachment workers in column 5 and insignificant for more workers with some labor force attachment in column 6 .
} 
columns. ${ }^{49}$ For these samples, the standard deviation of log earnings is substantially higher and a larger fraction of workers experience job changes, transitions to non-employment, and longer nonemployment spells.

To estimate the correlation of these measures with mortality, we present results from logitmodels as shown in equation (1). These are shown for different samples and specifications in Table 4 and Appendix Table 6. All models include age dummies, year dummies, and log average earnings as controls, and all results are robust to inclusion of measures of the number of quarters worked. The main result of Table 4 is that the effect of the standard deviation of log earnings on mortality is positive, non-linear (the effect is positive and decreasing and well-captured by a log-specification, see Figure 4), and substantial. The results in column 1 of the first panel in Table 4 suggest that a 20\% increase in the standard deviation of earnings leads to an increase in the risk of death of about $4 \%$. In the pooled model, this corresponds to the effect of a 10\% decline in average earnings. The estimates are also robust to inclusions of other measures career shocks such as quarters worked, non-employment transitions, or the presence and frequency of large earnings drops.

Given it is calculated over a relatively short period of time (six years), we interpret the standard deviation of log-earnings as a measure of the transitory component $\left(u_{i t}\right)$ of the earnings process in equation (A1). We believe this to be a reasonable interpretation of the short-term earnings risk an individual faces. This interpretation is helped by the fact that the effect of the standard deviation is robust to the inclusion of indicators for the presence of large earnings shocks and non-employment transitions. Thus, we interpret the results in Table 4 to imply that the variability a worker faces in the labor market is negatively correlated with long-term health outcomes. Clearly, less healthy workers are likely to have higher standard deviations in earnings. However, the fact that the result also attains for very stable workers and is largely unaffected by the inclusion of log average earnings as additional control suggests it may not be fully explained by omitted variable bias. Reverse causation is not an issue given that the follow up period begins seven years after the baseline period at which the standard deviation is calculated.

Table 4 also shows results for other measures of career instability and more broadly defined samples of workers. The effect of the standard deviation is present across all samples; it is smaller for the broader sample, partly due to the fact that the range of values the standard deviation takes is much higher (such that a change of two standard deviations would have a more similar effect).

\footnotetext{
${ }^{49}$ Note that some mobility is possible even for those workers due to temporary layoffs and short breaks in the employment spell.
} 
Similarly, its effect is essentially unaffected if it is calculated over a much longer time period. Not surprisingly, for the main high-attachment sample, the only other significant effect is the presence of large earnings declines. However, this effect fades for the sample with the long baseline in the bottom of the table. For the broader samples, transitions to non-employment tend to raise mortality even when controlling for the incidence of large earnings declines. This result stands in contrast to the sometimes beneficial effect of the amount of time spend in non-employment. Once we control for the number of times individuals transit to non-employment, the incidence of job changes has no effect for either sample.

Overall, we interpret these results to signify that the interaction between individual health and career outcomes is potentially complex, and goes beyond a simple correlation between earnings and mortality. In particular, it appears that various measures capturing the degree of earnings and employment stability have robust effect on mortality, too. It appears that workers with unstable careers die younger. To address part of the concerns of omitted variable bias afflicting these correlations, in the next section we study the short and long-term mortality effect of an explicit shock to workers careers - an involuntary job loss in the course of mass-layoffs at the plant level. 
Table 1: Sample Characteristics in Baseline Period (1974-1979) by Displacement Status

\begin{tabular}{|c|c|c|c|c|c|c|}
\hline & \multicolumn{3}{|c|}{ Work Every Year 1980-86 } & \multicolumn{3}{|c|}{ No Work Restriction 1980-86 } \\
\hline & $\begin{array}{c}\text { All } \\
\text { Workers } \\
\end{array}$ & $\begin{array}{c}\text { Workers } \\
\text { Displaced } \\
\text { at Mass- } \\
\text { Layoff } \\
\end{array}$ & $\begin{array}{c}\text { Non- } \\
\text { Displaced } \\
\text { Workers } \\
\end{array}$ & $\begin{array}{c}\text { All } \\
\text { Workers } \\
\end{array}$ & $\begin{array}{l}\text { Workers } \\
\text { Displaced } \\
\text { at Mass- } \\
\text { Layoff } \\
\end{array}$ & $\begin{array}{c}\text { Non- } \\
\text { Displaced } \\
\text { Workers }\end{array}$ \\
\hline Sample Size & 15377 & 4802 & 10575 & 21323 & 7190 & 14133 \\
\hline Age in 1979 & $\begin{array}{l}37.54 \\
(7.014)\end{array}$ & $\begin{array}{l}37.02 \\
(7.295)\end{array}$ & $\begin{array}{c}37.77 \\
(6.870)\end{array}$ & $\begin{array}{l}37.36 \\
(7.114)\end{array}$ & $\begin{array}{c}37.09 \\
(7.406)\end{array}$ & $\begin{array}{l}37.49 \\
(6.956)\end{array}$ \\
\hline $\begin{array}{l}\text { Log Average Quarterly } \\
\text { Earnings in 1974-79 }\end{array}$ & $\begin{array}{c}\mathbf{8 . 7 5} \\
(0.334)\end{array}$ & $\begin{array}{c}\mathbf{8 . 7 0} \\
(0.337)\end{array}$ & $\begin{array}{c}8.77 \\
(0.330)\end{array}$ & $\begin{array}{c}8.74 \\
(0.358)\end{array}$ & $\begin{array}{c}\mathbf{8 . 7 0} \\
(0.346)\end{array}$ & $\begin{array}{c}\mathbf{8 . 7 6} \\
(0.362)\end{array}$ \\
\hline $\begin{array}{l}\text { Log Std. Dev. of Log Quarterly } \\
\text { Earnings 1974-79 }\end{array}$ & $\begin{array}{l}-1.678 \\
(0.711)\end{array}$ & $\begin{array}{l}-\mathbf{- 1 . 5 4 5} \\
(0.749)\end{array}$ & $\begin{array}{l}\mathbf{- 1 . 7 3 8} \\
(0.685)\end{array}$ & $\begin{array}{l}\mathbf{- 1 . 6 3 8} \\
(0.731)\end{array}$ & $\begin{array}{l}-1.484 \\
(0.768)\end{array}$ & $\begin{array}{l}-1.716 \\
(0.699)\end{array}$ \\
\hline $\begin{array}{l}\text { Percent Change in Quarterly } \\
\text { Earnings 1974-79 }\end{array}$ & $\begin{array}{c}\mathbf{0 . 4 6 8} \\
(5.645)\end{array}$ & $\begin{array}{c}\mathbf{0 . 5 8 0} \\
(7.274)\end{array}$ & $\begin{array}{c}\mathbf{0 . 4 1 8} \\
(4.729)\end{array}$ & $\begin{array}{c}\mathbf{0 . 5 1 7} \\
(5.769)\end{array}$ & $\begin{array}{c}\mathbf{0 . 6 8 2} \\
(7.733)\end{array}$ & $\begin{array}{c}\mathbf{0 . 4 3 4} \\
(4.453)\end{array}$ \\
\hline $\begin{array}{l}\text { Number of Quarters in Non- } \\
\text { Employment 1974-79 }\end{array}$ & $\begin{array}{c}\mathbf{0 . 4 5} \\
(0.913)\end{array}$ & $\begin{array}{c}\mathbf{0 . 5 4} \\
(1.031)\end{array}$ & $\begin{array}{c}\mathbf{0 . 4 0} \\
(0.851)\end{array}$ & $\begin{array}{c}\mathbf{0 . 4 8} \\
(0.978)\end{array}$ & $\begin{array}{c}\mathbf{0 . 5 8} \\
(1.102)\end{array}$ & $\begin{array}{c}\mathbf{0 . 4 3} \\
(0.905)\end{array}$ \\
\hline $\begin{array}{l}\text { Establishment Employment } \\
\text { Size in } 1979\end{array}$ & $\begin{array}{c}8608 \\
(13649)\end{array}$ & $\begin{array}{c}9040 \\
(15001)\end{array}$ & $\begin{array}{c}8412 \\
(12984)\end{array}$ & $\begin{array}{c}8564 \\
(13950)\end{array}$ & $\begin{array}{c}10459 \\
(16272)\end{array}$ & $\begin{array}{c}7599 \\
(12496)\end{array}$ \\
\hline $\begin{array}{l}\text { Fraction Durable Goods } \\
\text { Manufacturing (Non Steel) }\end{array}$ & $\begin{array}{c}\mathbf{0 . 3 0 4} \\
(0.460)\end{array}$ & $\begin{array}{c}\mathbf{0 . 3 6 5} \\
(0.481)\end{array}$ & $\begin{array}{c}\mathbf{0 . 2 7 7} \\
(0.448)\end{array}$ & $\begin{array}{c}\mathbf{0 . 2 9 8} \\
(0.457)\end{array}$ & $\begin{array}{c}\mathbf{0 . 3 5 0} \\
(0.477)\end{array}$ & $\begin{array}{c}\mathbf{0 . 2 7 1} \\
(0.445)\end{array}$ \\
\hline Fraction Steel Industries & $\begin{array}{c}\mathbf{0 . 1 7 7} \\
(0.382)\end{array}$ & $\begin{array}{c}\mathbf{0 . 2 5 9} \\
(0.438)\end{array}$ & $\begin{array}{c}\mathbf{0 . 1 4 0} \\
(0.347)\end{array}$ & $\begin{array}{c}\mathbf{0 . 1 8 0} \\
(0.384)\end{array}$ & $\begin{array}{c}\mathbf{0 . 2 9 1} \\
(0.454)\end{array}$ & $\begin{array}{c}\mathbf{0 . 1 2 3} \\
(0.328)\end{array}$ \\
\hline Fraction Other Manufacturing & $\begin{array}{c}\mathbf{0 . 1 9 5} \\
(0.396)\end{array}$ & $\begin{array}{c}\mathbf{0 . 1 8 4} \\
(0.388)\end{array}$ & $\begin{array}{c}\mathbf{0 . 2 0 0} \\
(0.400)\end{array}$ & $\begin{array}{c}\mathbf{0 . 1 9 1} \\
(0.393)\end{array}$ & $\begin{array}{c}\mathbf{0 . 1 6 5} \\
(0.371)\end{array}$ & $\begin{array}{c}\mathbf{0 . 2 0 4} \\
(0.403)\end{array}$ \\
\hline Fraction East PA & $\begin{array}{c}\mathbf{0 . 5 6 5} \\
(0.496)\end{array}$ & $\begin{array}{c}\mathbf{0 . 5 2 2} \\
(0.500)\end{array}$ & $\begin{array}{c}\mathbf{0 . 5 8 4} \\
(0.493)\end{array}$ & $\begin{array}{c}\mathbf{0 . 5 6 1} \\
(0.496)\end{array}$ & $\begin{array}{c}\mathbf{0 . 4 7 2} \\
(0.499) \\
-\end{array}$ & $\begin{array}{c}\mathbf{0 . 6 0 7} \\
(0.489)\end{array}$ \\
\hline $\begin{array}{l}\text { Log Average Quarterly } \\
\text { Earnings in 1987-91 }\end{array}$ & $\begin{array}{c}8.735 \\
(0.876)\end{array}$ & $\begin{array}{c}8.421 \\
(1.064)\end{array}$ & $\begin{array}{c}\mathbf{8 . 8 7 1} \\
(0.740)\end{array}$ & $\begin{array}{l}8.607 \\
(1.067)\end{array}$ & $\begin{array}{c}8.187 \\
(1.307)\end{array}$ & $\begin{array}{c}\mathbf{8 . 7 9 2} \\
(0.880)\end{array}$ \\
\hline $\begin{array}{l}\text { Log Std. Dev. of Log Quarterly } \\
\text { Earnings in 1987-91 }\end{array}$ & $\begin{array}{l}-1.396 \\
(0.737)\end{array}$ & $\begin{array}{l}\mathbf{- 1 . 1 9 9} \\
(0.758)\end{array}$ & $\begin{array}{l}\mathbf{- 1 . 4 8 1} \\
(0.712)\end{array}$ & $\begin{array}{l}-1.344 \\
(0.763)\end{array}$ & $\begin{array}{l}\mathbf{- 1 . 1 2 0} \\
(0.792)\end{array}$ & $\begin{array}{l}-1.440 \\
(0.730)\end{array}$ \\
\hline $\begin{array}{l}\text { Number of Quarters in Non- } \\
\text { Employment in 1987-91 }\end{array}$ & $\begin{array}{c}2.09 \\
(4.568)\end{array}$ & $\begin{array}{c}3.32 \\
(5.900)\end{array}$ & $\begin{array}{c}1.53 \\
(3.678)\end{array}$ & $\begin{array}{c}4.12 \\
(6.904)\end{array}$ & $\begin{array}{c}\mathbf{6 . 5 0} \\
(8.126)\end{array}$ & $\begin{array}{c}2.91 \\
(5.829)\end{array}$ \\
\hline
\end{tabular}

Notes: Standard deviations in parentheses. The samples only include male workers in stable employment 1974-1979 at an employer of size 50 in 1979. 
Panel A: Work Every Year 1980-86

Difference Adjusted For

\begin{tabular}{|c|c|c|c|c|c|c|c|}
\hline $\begin{array}{c}\text { Time } \\
\text { Period }\end{array}$ & All Workers & $\begin{array}{c}\text { Displaced } \\
\text { Workers }\end{array}$ & $\begin{array}{c}\text { Non- } \\
\text { Displaced } \\
\text { Workers }\end{array}$ & $\begin{array}{c}\text { Simple } \\
\text { Difference }\end{array}$ & Age & \multicolumn{2}{|r|}{$\begin{array}{l}\text { Age and Base } \\
\text { Period and } \\
\text { Change in } \\
\text { Earnings and } \\
\text { Firm Size } \\
\end{array}$} \\
\hline $87-02$ & $\begin{array}{c}\mathbf{5 . 7 2 0} \\
(0.165)\end{array}$ & $\begin{array}{c}\mathbf{6 . 2 0 4} \\
(0.308) \\
\end{array}$ & $\begin{array}{c}\mathbf{5 . 5 0 2} \\
(0.195)\end{array}$ & $\begin{array}{c}\mathbf{0 . 7 0 2} \\
(0.365)\end{array}$ & $\begin{array}{c}\mathbf{0 . 9 7 4} \\
(0.364)\end{array}$ & $\begin{array}{c}\mathbf{0 . 7 5 7} \\
(0.364)\end{array}$ & $\begin{array}{l}\mathbf{- 0 . 0 5 5} \\
(0.369)\end{array}$ \\
\hline $87-91$ & $\begin{array}{c}\mathbf{3 . 6 4 1} \\
(0.218)\end{array}$ & $\begin{array}{c}4.287 \\
(0.424)\end{array}$ & $\begin{array}{c}\mathbf{3 . 3 4 8} \\
(0.252)\end{array}$ & $\begin{array}{c}\mathbf{0 . 9 3 9} \\
(0.493)\end{array}$ & $\begin{array}{c}\mathbf{1 . 0 9 5} \\
(0.493)\end{array}$ & $\begin{array}{c}\mathbf{0 . 8 9 1} \\
(0.493)\end{array}$ & $\begin{array}{c}\mathbf{0 . 0 7 6} \\
(0.498)\end{array}$ \\
\hline $92-96$ & $\begin{array}{c}\mathbf{6 . 5 6 2} \\
(0.270)\end{array}$ & $\begin{array}{c}7.063 \\
(0.503)\end{array}$ & $\begin{array}{c}\mathbf{6 . 3 3 6} \\
(0.320)\end{array}$ & $\begin{array}{c}\mathbf{0 . 7 2 7} \\
(0.596)\end{array}$ & $\begin{array}{c}\mathbf{0 . 9 9 6} \\
(0.595)\end{array}$ & $\begin{array}{c}\mathbf{0 . 7 7 5} \\
(0.595)\end{array}$ & $\begin{array}{l}\mathbf{- 0 . 0 1 1} \\
(0.603)\end{array}$ \\
\hline $97-02$ & $\begin{array}{c}\mathbf{8 . 0 4 7} \\
(0.334)\end{array}$ & $\begin{array}{c}8.753 \\
(0.626)\end{array}$ & $\begin{array}{c}7.729 \\
(0.394)\end{array}$ & $\begin{array}{c}1.024 \\
(0.740)\end{array}$ & $\begin{array}{c}1.541 \\
(0.740)\end{array}$ & $\begin{array}{c}1.209 \\
(0.738)\end{array}$ & $\begin{array}{c}\mathbf{0 . 5 3 7} \\
(0.747)\end{array}$ \\
\hline
\end{tabular}

Notes: Deaths per 1000 per year. Standard errors in parentheses. Displaced Workers left jobs in a year in which their former firms' employment was 30\% or more below its 1974-1979 peak. Nondisplaced workers remain at their 1979 firm through 1986.

Panel B: No Work Restriction

Difference Adjusted For

\begin{tabular}{|c|c|c|c|c|c|c|c|}
\hline \multirow[b]{2}{*}{$\begin{array}{l}\text { Time } \\
\text { Period }\end{array}$} & \multirow[b]{2}{*}{ All Workers } & \multirow[b]{2}{*}{$\begin{array}{c}\text { Displaced } \\
\text { Workers }\end{array}$} & \multirow[b]{2}{*}{$\begin{array}{c}\text { Non- } \\
\text { Displaced } \\
\text { Workers }\end{array}$} & \multirow[b]{2}{*}{$\begin{array}{c}\text { Simple } \\
\text { Difference }\end{array}$} & \multirow[b]{2}{*}{ Age } & \multirow{2}{*}{\multicolumn{2}{|c|}{$\begin{array}{l}\text { Age and Base } \\
\text { Period and } \\
\text { Change in } \\
\text { Earnings and } \\
\text { Firm Size } \\
\end{array}$}} \\
\hline & & & & & & & \\
\hline $87-02$ & $\begin{array}{c}\mathbf{6 . 1 8 5} \\
(0.146) \\
\end{array}$ & $\begin{array}{r}7.031 \\
(0.269) \\
\end{array}$ & $\begin{array}{c}\mathbf{5 . 7 5 8} \\
(0.173) \\
\end{array}$ & $\begin{array}{c}1.273 \\
(0.319) \\
\end{array}$ & $\begin{array}{c}1.384 \\
(0.319) \\
\end{array}$ & $\begin{array}{c}1.004 \\
(0.319) \\
\end{array}$ & $\begin{array}{c}\mathbf{0 . 2 9 4} \\
(0.341) \\
\end{array}$ \\
\hline $80-86$ & $\begin{array}{c}2.465 \\
(0.128)\end{array}$ & $\begin{array}{c}\mathbf{3 . 9 9 6} \\
(0.279)\end{array}$ & $\begin{array}{c}1.677 \\
(0.130)\end{array}$ & $\begin{array}{c}2.320 \\
(0.307)\end{array}$ & $\begin{array}{c}2.344 \\
(0.307)\end{array}$ & $\begin{array}{l}\mathbf{1 . 9 7 8} \\
(0.307)\end{array}$ & $\begin{array}{l}\mathbf{- 0 . 1 4 7} \\
(0.152)\end{array}$ \\
\hline $87-91$ & $\begin{array}{c}4.008 \\
(0.194)\end{array}$ & $\begin{array}{c}4.946 \\
(0.372)\end{array}$ & $\begin{array}{c}3.533 \\
(0.224)\end{array}$ & $\begin{array}{c}1.412 \\
(0.434)\end{array}$ & $\begin{array}{c}1.468 \\
(0.434)\end{array}$ & $\begin{array}{c}1.091 \\
(0.434)\end{array}$ & $\begin{array}{c}\mathbf{0 . 3 2 3} \\
(0.457)\end{array}$ \\
\hline $92-96$ & $\begin{array}{c}\mathbf{6 . 9 8 1} \\
(0.237)\end{array}$ & $\begin{array}{c}7.776 \\
(0.425)\end{array}$ & $\begin{array}{c}\mathbf{6 . 5 6 2} \\
(0.284)\end{array}$ & $\begin{array}{c}1.249 \\
(0.517)\end{array}$ & $\begin{array}{c}1.348 \\
(0.516)\end{array}$ & $\begin{array}{c}\mathbf{0 . 9 6 6} \\
(0.515)\end{array}$ & $\begin{array}{c}\mathbf{0 . 4 1 6} \\
(0.558)\end{array}$ \\
\hline $97-02$ & $\begin{array}{c}\mathbf{8 . 6 9 9} \\
(0.296)\end{array}$ & $\begin{array}{c}9.527 \\
(0.536)\end{array}$ & $\begin{array}{c}8.284 \\
(0.354)\end{array}$ & $\begin{array}{c}1.243 \\
(0.642)\end{array}$ & $\begin{array}{c}1.481 \\
(0.640)\end{array}$ & $\begin{array}{c}1.096 \\
(0.640)\end{array}$ & $\begin{array}{c}\mathbf{0 . 5 4 3} \\
(0.694)\end{array}$ \\
\hline
\end{tabular}

Notes: Deaths per 1000 per year. Standard errors in parentheses. Displaced Workers left jobs in a year in which their former firms' employment was 30\% or more below its 1974-1979 peak. 
Table 3: Impact of Layoff During Mass-Layoff on Log-Odds of Death for Various Samples, Follow-Up Periods, and Specifications, Workers in Stable Employment 1974-1979, Employment Size 50 in 1979

\begin{tabular}{|c|c|c|c|c|c|c|c|c|c|}
\hline \multicolumn{2}{|c|}{ Mass-Layoff Sample: } & $\begin{array}{l}\text { No Work } \\
\text { Restriction }\end{array}$ & $\begin{array}{l}\text { Work Every } \\
\text { Year }\end{array}$ & $\begin{array}{l}\text { Work At } \\
\text { Least } 3 \\
\text { Years }\end{array}$ & $\begin{array}{l}\text { No Work } \\
\text { Restriction }\end{array}$ & $\begin{array}{l}\text { No Work } \\
\text { Restriction }\end{array}$ & $\begin{array}{l}\text { Work Every } \\
\text { Year }\end{array}$ & $\begin{array}{l}\text { Work At } \\
\text { Least } 3 \\
\text { Years }\end{array}$ & $\begin{array}{l}\text { No Work } \\
\text { Restriction }\end{array}$ \\
\hline \multicolumn{2}{|r|}{ Follow-Up Period: } & 1980-02 & $1987-02$ & 1987-02 & 1987-02 & $1980-02$ & 1987-02 & 1987-02 & 1987-02 \\
\hline & Cohort Range: & \multicolumn{4}{|c|}{ Born 1930-59 } & \multicolumn{4}{|c|}{ Born $\quad 1920-59$} \\
\hline \multicolumn{2}{|c|}{ Specification: } & (1) & (3) & (5) & (7) & (2) & (4) & (6) & (8) \\
\hline (A) & $\begin{array}{l}\text { Baseline Model with Average } \\
\text { and Std. Dev. of Earnings in } \\
1974-79\end{array}$ & $\begin{array}{c}\mathbf{0 . 2 7 5} \\
(0.041)\end{array}$ & $\begin{array}{c}\mathbf{0 . 1 4 5} \\
(0.056)\end{array}$ & $\begin{array}{c}\mathbf{0 . 1 6 6} \\
(0.046)\end{array}$ & $\begin{array}{c}\mathbf{0 . 1 7 0} \\
(0.045)\end{array}$ & $\begin{array}{c}\mathbf{0 . 1 5 4} \\
(0.025)\end{array}$ & $\begin{array}{c}\mathbf{0 . 0 8 9} \\
(0.039)\end{array}$ & $\begin{array}{c}\mathbf{0 . 1 2 2} \\
(0.028)\end{array}$ & $\begin{array}{c}\mathbf{0 . 1 1 1} \\
(0.027)\end{array}$ \\
\hline (B) & $\begin{array}{l}\text { Model in Row (A) with 1-Digit } \\
\text { Industry Fixed Effects }\end{array}$ & $\begin{array}{c}\mathbf{0 . 2 6 2} \\
(0.043)\end{array}$ & $\begin{array}{c}\mathbf{0 . 1 2 9} \\
(0.058)\end{array}$ & $\begin{array}{c}\mathbf{0 . 1 4 5} \\
(0.048)\end{array}$ & $\begin{array}{c}\mathbf{0 . 1 4 9} \\
(0.047)\end{array}$ & $\begin{array}{c}\mathbf{0 . 1 3 9} \\
(0.026)\end{array}$ & $\begin{array}{c}\mathbf{0 . 0 7 6} \\
(0.040)\end{array}$ & $\begin{array}{c}\mathbf{0 . 1 0 4} \\
(0.029)\end{array}$ & $\begin{array}{c}\mathbf{0 . 0 9 2} \\
(0.028)\end{array}$ \\
\hline (C) & $\begin{array}{l}\text { Model in Row (A) with 1-Digit } \\
\text { Industry Effects and Added } \\
\text { Career Variables }\end{array}$ & $\begin{array}{c}\mathbf{0 . 2 4 7} \\
(0.044)\end{array}$ & $\begin{array}{c}\mathbf{0 . 1 0 2} \\
(0.060)\end{array}$ & $\begin{array}{c}\mathbf{0 . 1 1 7} \\
(0.050)\end{array}$ & $\begin{array}{c}\mathbf{0 . 1 2 9} \\
(0.049)\end{array}$ & $\begin{array}{c}\mathbf{0 . 1 3 4} \\
(0.026)\end{array}$ & $\begin{array}{c}\mathbf{0 . 0 6 6} \\
(0.041)\end{array}$ & $\begin{array}{c}\mathbf{0 . 1 0 0} \\
(0.030)\end{array}$ & $\begin{array}{c}\mathbf{0 . 0 8 9} \\
(0.029)\end{array}$ \\
\hline (D) & $\begin{array}{l}\text { Model in Row (A) with Industry } \\
\text { Effects, Career*Age } \\
\text { Interactions }\end{array}$ & $\begin{array}{c}\mathbf{0 . 2 6 2} \\
(0.043)\end{array}$ & $\begin{array}{c}\mathbf{0 . 1 2 7} \\
(0.058)\end{array}$ & $\begin{array}{c}\mathbf{0 . 1 4 4} \\
(0.048)\end{array}$ & $\begin{array}{c}\mathbf{0 . 1 4 9} \\
(0.047)\end{array}$ & $\begin{array}{c}\mathbf{0 . 1 4 3} \\
(0.026)\end{array}$ & $\begin{array}{c}\mathbf{0 . 0 7 7} \\
(0.040)\end{array}$ & $\begin{array}{c}\mathbf{0 . 1 0 5} \\
(0.029)\end{array}$ & $\begin{array}{c}\mathbf{0 . 0 9 4} \\
(0.028)\end{array}$ \\
\hline (E) & $\begin{array}{l}\text { Linear Probability Model } \\
\text { (Specification Row B) }\end{array}$ & $\begin{array}{c}\mathbf{0 . 0 0 1 4} \\
(0.00027)\end{array}$ & $\begin{array}{c}\mathbf{0 . 0 0 0 8} \\
(0.00035)\end{array}$ & $\begin{array}{c}\mathbf{0 . 0 0 1 0} \\
(0.00032)\end{array}$ & $\begin{array}{c}\mathbf{0 . 0 0 1 0} \\
(0.00033)\end{array}$ & $\begin{array}{c}\mathbf{0 . 0 0 1 5} \\
(0.00031)\end{array}$ & $\begin{array}{c}\mathbf{0 . 0 0 0 8} \\
(0.00042)\end{array}$ & $\begin{array}{c}\mathbf{0 . 0 0 1 4} \\
(0.00039)\end{array}$ & $\begin{array}{c}\mathbf{0 . 0 0 1 3} \\
(0.00039)\end{array}$ \\
\hline (F) & $\begin{array}{l}\text { Linear Probability Model } \\
\text { (Spedificattion Row A) with } \\
\text { Firm Effects }\end{array}$ & $\begin{array}{c}\mathbf{0 . 0 0 1 9} \\
(0.00051)\end{array}$ & $\begin{array}{c}\mathbf{0 . 0 0 0 8} \\
(0.00054)\end{array}$ & $\begin{array}{c}\mathbf{0 . 0 0 0 6} \\
(0.00051)\end{array}$ & $\begin{array}{c}\mathbf{0 . 0 0 0 6} \\
(0.00054)\end{array}$ & $\begin{array}{c}\mathbf{0 . 0 0 1 5} \\
(0.00053)\end{array}$ & $\begin{array}{c}\mathbf{0 . 0 0 1 0} \\
(0.00075)\end{array}$ & $\begin{array}{c}\mathbf{0 . 0 0 1 3} \\
(0.00059)\end{array}$ & $\begin{array}{c}\mathbf{0 . 0 0 0 8} \\
(0.00059)\end{array}$ \\
\hline (G) & $\begin{array}{l}\text { Percentage Effect For Linear } \\
\text { Probability Model in Row (E) }\end{array}$ & 0.274 & 0.135 & 0.150 & 0.155 & 0.148 & 0.085 & 0.114 & 0.101 \\
\hline (H) & $\begin{array}{l}\text { Percentage Effect For Linear } \\
\text { Model in Row (F) }\end{array}$ & 0.369 & 0.131 & 0.091 & 0.090 & 0.147 & 0.102 & 0.106 & 0.066 \\
\hline & Observations & 478,664 & 237,122 & 319,358 & 327,775 & 681,614 & 301,531 & 442,643 & 458,910 \\
\hline
\end{tabular}

Notes: Dependent variable is the log odds of death in a year between 1980 or 1987 and 2002. The entries in the tables are the coefficient on a dummy for job loss during mass-layoff. See Figure 3 and the Appendix for marginal effects. All models include year effects and a quartic in age as well as the indicated variables in the column "Specification." In all models, the average of quarterly earnings from 1974-79 is entered in logs; the standard deviation is of the log quarterly earnings, and also entered in logs. The additional "Career Variables" in Rows (C) to (F) are growth in quarterly earnings from 1974-79 and the total time spent in non-

employment in 1974-79. Row (D) interacts the log of average earnings and the log of the standard deviation of log earnings with five dummies for age at layoff. 
Table 4: Coefficients on Career Variables in Extended Log-Odds of Death Model, Various Samples, Workers in Stable Employment 19741979, Employment Size 50 in 1979

\begin{tabular}{|c|c|c|c|c|c|c|c|c|}
\hline Mass-Layoff Sample: & $\begin{array}{l}\text { No Work } \\
\text { Restriction }\end{array}$ & $\begin{array}{l}\text { Work Every } \\
\text { Year }\end{array}$ & $\begin{array}{c}\text { Work At } \\
\text { Least } 3 \\
\text { Years }\end{array}$ & $\begin{array}{l}\text { No Work } \\
\text { Restriction }\end{array}$ & $\begin{array}{l}\text { No Work } \\
\text { Restriction }\end{array}$ & $\begin{array}{l}\text { Work Every } \\
\text { Year }\end{array}$ & $\begin{array}{c}\text { Work At } \\
\text { Least } 3 \\
\text { Years }\end{array}$ & $\begin{array}{l}\text { No Work } \\
\text { Restriction }\end{array}$ \\
\hline Follow-Up Period: & 1980-02 & 1987-02 & 1987-02 & 1987-02 & 1980-02 & 1987-02 & 1987-02 & 1987-02 \\
\hline \multirow[t]{2}{*}{ Cohort Range: } & & Born & $1930-59$ & & & Born & 1920-59 & \\
\hline & (1) & (2) & (3) & (4) & (5) & (6) & (7) & (8) \\
\hline Displacement-Dummy & $\begin{array}{c}\mathbf{0 . 2 4 7} \\
(0.044)\end{array}$ & $\begin{array}{c}\mathbf{0 . 1 0 2} \\
(0.060)\end{array}$ & $\begin{array}{c}\mathbf{0 . 1 1 7} \\
(0.050)\end{array}$ & $\begin{array}{c}\mathbf{0 . 1 2 9} \\
(0.049)\end{array}$ & $\begin{array}{c}\mathbf{0 . 1 3 5} \\
(0.026)\end{array}$ & $\begin{array}{l}\mathbf{0 . 0 6 6} \\
(0.041)\end{array}$ & $\begin{array}{c}\mathbf{0 . 1 0 0} \\
(0.030)\end{array}$ & $\begin{array}{c}\mathbf{0 . 0 8 9} \\
(0.029)\end{array}$ \\
\hline $\begin{array}{l}\text { Log(Average Quarterly } \\
\text { Earnings 1974-79) }\end{array}$ & $\begin{array}{l}-0.536 \\
(0.064)\end{array}$ & $\begin{array}{l}-\mathbf{0 . 4 9 1} \\
(0.091)\end{array}$ & $\begin{array}{l}-\mathbf{0 . 5 3 2} \\
(0.072)\end{array}$ & $\begin{array}{l}-0.543 \\
(0.070)\end{array}$ & $\begin{array}{l}-\mathbf{0 . 4 7 4} \\
(0.036)\end{array}$ & $\begin{array}{l}\mathbf{- 0 . 4 3 1} \\
(0.058)\end{array}$ & $\begin{array}{l}-\mathbf{0 . 4 6 5} \\
(0.041)\end{array}$ & $\begin{array}{l}-0.472 \\
(0.039)\end{array}$ \\
\hline $\begin{array}{l}\text { Log(Std. Dev. of Log Quarterly } \\
\text { Earnings 1974-79) }\end{array}$ & $\begin{array}{c}\mathbf{0 . 1 3 0} \\
(0.035)\end{array}$ & $\begin{array}{c}\mathbf{0 . 1 4 4} \\
(0.046)\end{array}$ & $\begin{array}{c}\mathbf{0 . 1 0 9} \\
(0.039)\end{array}$ & $\begin{array}{c}\mathbf{0 . 1 0 4} \\
(0.038)\end{array}$ & $\begin{array}{c}\mathbf{0 . 1 2 1} \\
(0.020)\end{array}$ & $\begin{array}{c}\mathbf{0 . 1 0 7} \\
(0.032)\end{array}$ & $\begin{array}{c}\mathbf{0 . 0 9 7} \\
(0.023)\end{array}$ & $\begin{array}{c}\mathbf{0 . 1 0 3} \\
(0.022)\end{array}$ \\
\hline $\begin{array}{l}\text { Number of Quarters in Non- } \\
\text { Employment 1974-79 }\end{array}$ & $\begin{array}{l}-0.123 \\
(0.034)\end{array}$ & $\begin{array}{l}-0.122 \\
(0.047)\end{array}$ & $\begin{array}{l}-\mathbf{0 . 0 9 7} \\
(0.037)\end{array}$ & $\begin{array}{l}\mathbf{- 0 . 0 9 4} \\
(0.036)\end{array}$ & $\begin{array}{l}-\mathbf{0 . 0 9 1} \\
(0.020)\end{array}$ & $\begin{array}{l}-\mathbf{0 . 0 7 7} \\
(0.033)\end{array}$ & $\begin{array}{l}-\mathbf{0 . 0 7 0} \\
(0.023)\end{array}$ & $\begin{array}{l}-\mathbf{0 . 0 6 7} \\
(0.022)\end{array}$ \\
\hline $\begin{array}{l}\text { Percent Change in Quarterly } \\
\text { Earnings 1974-79 }\end{array}$ & $\begin{array}{l}\mathbf{- 0 . 0 4 4} \\
(0.062)\end{array}$ & $\begin{array}{l}-\mathbf{0 . 0 2 1} \\
(0.084)\end{array}$ & $\begin{array}{l}\mathbf{- 0 . 0 2 6} \\
(0.069)\end{array}$ & $\begin{array}{l}\mathbf{- 0 . 0 3 3} \\
(0.067)\end{array}$ & $\begin{array}{l}\mathbf{- 0 . 1 2 8} \\
(0.038)\end{array}$ & $\begin{array}{c}\mathbf{0 . 0 4 4} \\
(0.062)\end{array}$ & $\begin{array}{l}\mathbf{- 0 . 0 6 4} \\
(0.044)\end{array}$ & $\begin{array}{l}\mathbf{- 0 . 1 0 1} \\
(0.042)\end{array}$ \\
\hline $\begin{array}{l}\text { 1-Digit Dummies for } 1979 \\
\text { Industry }\end{array}$ & Yes & Yes & Yes & Yes & Yes & Yes & Yes & Yes \\
\hline Observations & 437,420 & 219,284 & 291,923 & 299,450 & 631,411 & 280,872 & 409,692 & 424,765 \\
\hline
\end{tabular}

Notes: These are coefficients on covariates included in Model C of Table 4. Please refer to Notes of Table 4 for further explanations. 
Table 5: Effect of Job Loss at Mass-Layoff By Time Since Displacement, No Work Restsriction 1980-1986, Alternative AgeGroups

\begin{tabular}{|c|c|c|c|c|c|c|}
\hline & (1) & (2) & (3) & (4) & (5) & (6) \\
\hline & \multicolumn{3}{|c|}{ Born 1930-59 } & \multicolumn{3}{|c|}{ Born 1920-59 } \\
\hline Log(Average Quarterly Earnings) & $\begin{array}{l}-0.458 \\
(0.057)\end{array}$ & $\begin{array}{l}-0.463 \\
(0.057)\end{array}$ & $\begin{array}{l}-0.463 \\
(0.057)\end{array}$ & $\begin{array}{l}-0.413 \\
(0.032)\end{array}$ & $\begin{array}{l}-0.413 \\
(0.032)\end{array}$ & $\begin{array}{l}-0.414 \\
(0.032)\end{array}$ \\
\hline $\begin{array}{l}\text { Log(Standard Deviation of Log } \\
\text { Quarterly Earnings) }\end{array}$ & $\begin{array}{c}0.143 \\
(0.029)\end{array}$ & $\begin{array}{c}0.146 \\
(0.029)\end{array}$ & $\begin{array}{c}0.146 \\
(0.029)\end{array}$ & $\begin{array}{c}0.135 \\
(0.017)\end{array}$ & $\begin{array}{c}0.139 \\
(0.017)\end{array}$ & $\begin{array}{c}0.139 \\
(0.017)\end{array}$ \\
\hline Displacement-Dummy & $\begin{array}{c}0.250 \\
(0.043)\end{array}$ & & & $\begin{array}{c}0.135 \\
(0.026)\end{array}$ & & \\
\hline Displacement Year & & $\begin{array}{c}0.983 \\
(0.119)\end{array}$ & $\begin{array}{c}0.982 \\
(0.119)\end{array}$ & & $\begin{array}{c}0.297 \\
(0.072)\end{array}$ & $\begin{array}{c}0.297 \\
(0.071)\end{array}$ \\
\hline Displacement Year +1 & & $\begin{array}{c}0.688 \\
(0.189)\end{array}$ & $\begin{array}{c}0.685 \\
(0.189)\end{array}$ & & $\begin{array}{c}0.490 \\
(0.099)\end{array}$ & $\begin{array}{c}0.489 \\
(0.099)\end{array}$ \\
\hline Displacement Year $+2-3$ & & $\begin{array}{c}0.555 \\
(0.137)\end{array}$ & $\begin{array}{c}0.549 \\
(0.137)\end{array}$ & & $\begin{array}{c}0.243 \\
(0.077)\end{array}$ & $\begin{array}{c}0.240 \\
(0.077)\end{array}$ \\
\hline Displacement Year $+4-5$ & & $\begin{array}{c}0.249 \\
(0.139)\end{array}$ & $\begin{array}{c}0.240 \\
(0.138)\end{array}$ & & $\begin{array}{c}0.053 \\
(0.076)\end{array}$ & $\begin{array}{c}0.048 \\
(0.075)\end{array}$ \\
\hline Displacement Year + 6-10 & & $\begin{array}{c}0.179 \\
(0.081)\end{array}$ & & & $\begin{array}{c}0.119 \\
(0.045)\end{array}$ & \\
\hline Displacement Year + 11-15 & & $\begin{array}{l}0.065 \\
(0.07)\end{array}$ & & & $\begin{array}{c}0.047 \\
(0.041)\end{array}$ & \\
\hline Displacement Year $+16+$ & & $\begin{array}{c}0.153 \\
(0.077)\end{array}$ & & & $\begin{array}{c}0.142 \\
(0.047)\end{array}$ & \\
\hline Displacement Year $+6+$ & & & $\begin{array}{c}0.127 \\
(0.048)\end{array}$ & & & $\begin{array}{c}0.098 \\
(0.029)\end{array}$ \\
\hline Observations & 478,664 & 478,664 & 478,664 & 681,614 & 681,614 & 681,614 \\
\hline
\end{tabular}

Notes: Samples are workers in stable jobs from 1974-79 with an employer of over 50 workers. Dependent variable is the log odds of death. Columns (1)-(3) include workers born 1930-59. Columns (4)-(6) inclue workers born 1920-59. All models include industry fixed effects. 
Table 6: Effect of Mass-Layoff at Establishment Level on Mortality and Earnings Pooling Movers and Stayers, No Work Restriction, Born 1920+ (Intent-To-Treat Estimates)

\begin{tabular}{|c|c|c|c|c|}
\hline \multirow[t]{2}{*}{ Mass Layoff Definition: } & \multicolumn{2}{|c|}{$\begin{array}{c}\text { 30\% Drop Relative to } \\
\text { Employment in 1974-79 }\end{array}$} & \multicolumn{2}{|c|}{$\begin{array}{r}30 \% \text { Drop Relative to } \\
\text { Employment in Past Ye }\end{array}$} \\
\hline & Model 1 & Model 2 & Model 1 & Model \\
\hline \multicolumn{5}{|c|}{ Panel A: Average Effect on Hazard of Death } \\
\hline 1987-2002 & $\begin{array}{c}\mathbf{0 . 0 4 6} \\
(0.025)\end{array}$ & $\begin{array}{c}\mathbf{0 . 0 0 7} \\
(0.027)\end{array}$ & $\begin{array}{c}\mathbf{0 . 0 6 6} \\
(0.029)\end{array}$ & $\begin{array}{c}\mathbf{0 . 0 2 7} \\
(0.031)\end{array}$ \\
\hline 1980-2002 & $\begin{array}{c}\mathbf{0 . 0 2 1} \\
(0.028)\end{array}$ & $\begin{array}{c}-\mathbf{0 . 0 1 9} \\
(0.030)\end{array}$ & $\begin{array}{c}\mathbf{0 . 0 6 7} \\
(0.032)\end{array}$ & $\begin{array}{c}\mathbf{0 . 0 2 9} \\
(0.034)\end{array}$ \\
\hline
\end{tabular}

Panel B: Dynamic Effect on Hazard of Death, 1980-2002

\begin{tabular}{|c|c|c|c|c|}
\hline$t-4$ to $t-3$ & $\begin{array}{c}\mathbf{0 . 1 9 7} \\
(0.133)\end{array}$ & $\begin{array}{c}\mathbf{0 . 1 9 2} \\
(0.133)\end{array}$ & $\begin{array}{c}\mathbf{0 . 0 6 6} \\
(0.174)\end{array}$ & $\begin{array}{c}\mathbf{0 . 0 2 7} \\
(0.174)\end{array}$ \\
\hline $\mathrm{t}-2$ to $\mathrm{t}-1$ & $\begin{array}{c}\mathbf{0 . 1 6 2} \\
(0.098)\end{array}$ & $\begin{array}{c}\mathbf{0 . 1 4 2} \\
(0.099)\end{array}$ & $\begin{array}{c}\mathbf{0 . 1 6 6} \\
(0.117)\end{array}$ & $\begin{array}{c}\mathbf{0 . 1 3 9} \\
(0.118)\end{array}$ \\
\hline Year of Mass Layoff $(=t)$ & $\begin{array}{c}\mathbf{0 . 3 8 6} \\
(0.104)\end{array}$ & $\begin{array}{c}\mathbf{0 . 3 6 7} \\
(0.105)\end{array}$ & $\begin{array}{c}\mathbf{0 . 3 9 7} \\
(0.133)\end{array}$ & $\begin{array}{c}\mathbf{0 . 3 7 2} \\
(0.133)\end{array}$ \\
\hline$t+1$ to $t+10$ & $\begin{array}{c}\mathbf{0 . 0 5 6} \\
(0.038)\end{array}$ & $\begin{array}{c}\mathbf{0 . 0 3 5} \\
(0.040)\end{array}$ & $\begin{array}{c}\mathbf{0 . 0 3 3} \\
(0.044)\end{array}$ & $\begin{array}{c}\mathbf{0 . 0 0 7} \\
(0.045)\end{array}$ \\
\hline$t+11$ to $t+22$ & $\begin{array}{c}\mathbf{0 . 0 4 7} \\
(0.033)\end{array}$ & $\begin{array}{c}\mathbf{0 . 0 2 1} \\
(0.035)\end{array}$ & $\begin{array}{c}\mathbf{0 . 1 0 6} \\
(0.037)\end{array}$ & $\begin{array}{c}\mathbf{0 . 0 7 8} \\
(0.038)\end{array}$ \\
\hline
\end{tabular}

Panel C: Average Effect on Annual Earnings

$\begin{array}{lcccr}\mathbf{1 9 8 7 - 2 0 0 2} & \mathbf{- 0 . 1 8 1} & \mathbf{- 0 . 1 0 3} & \mathbf{- 0 . 2 5 6} & \mathbf{- 0 . 1 8 0} \\ & (0.003) & (0.003) & (0.004) & (0.004) \\ \mathbf{1 9 8 0 - 2 0 0 2} & \mathbf{- 0 . 2 4 1} & \mathbf{- 0 . 1 4 0} & \mathbf{- 0 . 3 2 9} & \mathbf{- 0 . 2 3 0} \\ & (0.006) & (0.006) & (0.007) & (0.007)\end{array}$

Panel D: Dynamic Effect on Annual Earnings, 1980-2002

\begin{tabular}{|c|c|c|c|c|}
\hline $\mathrm{t}-4$ to $\mathrm{t}-3$ & $\begin{array}{c}\mathbf{0 . 0 0 5} \\
(0.007)\end{array}$ & $\begin{array}{c}\mathbf{0 . 0 4 3} \\
(0.007)\end{array}$ & $\begin{array}{c}\mathbf{0 . 0 0 9} \\
(0.008)\end{array}$ & $\begin{array}{c}\mathbf{0 . 0 7 3} \\
(0.008)\end{array}$ \\
\hline$t-2$ to $t-1$ & $\begin{array}{l}\mathbf{- 0 . 1 1 9} \\
(0.006)\end{array}$ & $\begin{array}{c}-\mathbf{0 . 0 5 2} \\
(0.006)\end{array}$ & $\begin{array}{r}-\mathbf{0 . 2 1 6} \\
(0.007)\end{array}$ & $\begin{array}{r}-\mathbf{0 . 1 4 3} \\
(0.007)\end{array}$ \\
\hline Year of Mass Layoff $(=t)$ & $\begin{array}{l}-\mathbf{0 . 2 7 2} \\
(0.007)\end{array}$ & $\begin{array}{c}-0.214 \\
(0.007)\end{array}$ & $\begin{array}{r}-\mathbf{0 . 4 3 2} \\
(0.010)\end{array}$ & $\begin{array}{l}-\mathbf{0 . 3 6 6} \\
(0.010)\end{array}$ \\
\hline$t+1$ to $t+10$ & $\begin{array}{l}-\mathbf{0 . 2 9 0} \\
(0.004)\end{array}$ & $\begin{array}{r}-\mathbf{0 . 2 3 0} \\
(0.004)\end{array}$ & $\begin{array}{l}-\mathbf{0 . 3 6 4} \\
(0.004)\end{array}$ & $\begin{array}{l}-\mathbf{- 0 . 3 0 1} \\
(0.004)\end{array}$ \\
\hline$t+11$ to $t+22$ & $\begin{array}{c}\mathbf{- 0 . 1 4 1} \\
(0.026)\end{array}$ & $\begin{array}{l}-0.137 \\
(0.026)\end{array}$ & $\begin{array}{r}-0.120 \\
(0.055)\end{array}$ & $\begin{array}{l}-\mathbf{- 0 . 1 0 8} \\
(0.054)\end{array}$ \\
\hline
\end{tabular}

Notes: Entries are coefficients on establishment-level mass-layoff dummy in logit model of the event of dying in a given year. All regressions include a quartic in age, year effects, and the log of the average and standard deviation of annual earnings in 1974-79 as control. In addition, Model 2 includes six dummies for 1979 industry. Standard errors are in parentheses. 
Table 7: Mortality Impact of Job Displacment by Age, Industry, Earnings, Region of Job Loss, Workers Born 1920-1959

\begin{tabular}{|c|c|c|c|}
\hline Work Restriction in $1980-1986$ & $\begin{array}{l}\text { No Work } \\
\text { Restriction }\end{array}$ & Work Every Year & $\begin{array}{c}\text { Work At Least } 3 \\
\text { Years }\end{array}$ \\
\hline Period of Death Follow-Up & 1980-2002 & 1987-2002 & 1987-2002 \\
\hline Displacement-Dummy & $\begin{array}{l}\mathbf{0 . 1 3 9} \\
(0.026)\end{array}$ & $\begin{array}{l}\mathbf{0 . 0 7 6} \\
(0.040)\end{array}$ & $\begin{array}{c}\mathbf{0 . 1 9 7} \\
(0.031)\end{array}$ \\
\hline Displacement aged 30-39 & $\begin{array}{l}\mathbf{0 . 3 1 3} \\
(0.090)\end{array}$ & $\begin{array}{c}\mathbf{0 . 1 8 1} \\
(0.130)\end{array}$ & $\begin{array}{c}\mathbf{0 . 1 7 2} \\
(0.103)\end{array}$ \\
\hline Displacement aged $40-49$ & $\begin{array}{c}\mathbf{0 . 2 6 6} \\
(0.058)\end{array}$ & $\begin{array}{c}\mathbf{0 . 0 9 4} \\
(0.082)\end{array}$ & $\begin{array}{c}\mathbf{0 . 1 4 4} \\
(0.066)\end{array}$ \\
\hline Displacement aged 50-59 & $\begin{array}{c}\mathbf{0 . 2 1 9} \\
(0.034)\end{array}$ & $\begin{array}{c}\mathbf{0 . 0 7 1} \\
(0.055)\end{array}$ & $\begin{array}{c}\mathbf{0 . 1 4 1} \\
(0.040)\end{array}$ \\
\hline Displacement aged 60-69 & $\begin{array}{l}-0.005 \\
(0.036)\end{array}$ & $\begin{array}{c}\mathbf{0 . 0 4 6} \\
(0.066)\end{array}$ & $\begin{array}{c}\mathbf{0 . 0 4 4} \\
(0.041)\end{array}$ \\
\hline $\begin{array}{l}\text { Displaced in Non-Manufacturing } \\
\text { Goods Sector }\end{array}$ & $\begin{array}{c}\mathbf{0 . 0 6 8} \\
(0.124)\end{array}$ & $\begin{array}{l}-\mathbf{0 . 0 7 1} \\
(0.213)\end{array}$ & $\begin{array}{l}0.255 \\
(0.151)\end{array}$ \\
\hline $\begin{array}{l}\text { Displaced in Non-Durables } \\
\text { Manufacturing }\end{array}$ & $\begin{array}{c}\mathbf{0 . 0 7 9} \\
(0.056)\end{array}$ & $\begin{array}{l}-\mathbf{0 . 0 3 6} \\
(0.086)\end{array}$ & $\begin{array}{c}\mathbf{0 . 0 7 1} \\
(0.064)\end{array}$ \\
\hline Displaced in Steel Manufacturing & $\begin{array}{c}\mathbf{0 . 1 3 6} \\
(0.057)\end{array}$ & $\begin{array}{c}\mathbf{0 . 1 3 7} \\
(0.088)\end{array}$ & $\begin{array}{c}\mathbf{0 . 2 0 2} \\
(0.072)\end{array}$ \\
\hline $\begin{array}{l}\text { Displaced in Other Durables } \\
\text { Manufacturing }\end{array}$ & $\begin{array}{c}\mathbf{0 . 1 9 1} \\
(0.044)\end{array}$ & $\begin{array}{c}\mathbf{0 . 1 7 3} \\
(0.068)\end{array}$ & $\begin{array}{c}\mathbf{0 . 2 8 8} \\
(0.054)\end{array}$ \\
\hline $\begin{array}{l}\text { Displaced in Transportation, } \\
\text { Construction, Public Utilities }\end{array}$ & $\begin{array}{c}\mathbf{0 . 2 4 8} \\
(0.086)\end{array}$ & $\begin{array}{c}\mathbf{0 . 1 4 3} \\
(0.137)\end{array}$ & $\begin{array}{c}\mathbf{0 . 2 4 3} \\
(0.090)\end{array}$ \\
\hline Displaced in Trade & $\begin{array}{l}\mathbf{- 0 . 0 7 4} \\
(0.097)\end{array}$ & $\begin{array}{l}-0.239 \\
(0.152)\end{array}$ & $\begin{array}{c}\mathbf{0 . 0 4 0} \\
(0.096)\end{array}$ \\
\hline Displaced in Services & $\begin{array}{c}\mathbf{0 . 2 2 0} \\
(0.105)\end{array}$ & $\begin{array}{c}\mathbf{0 . 1 0 8} \\
(0.185)\end{array}$ & $\begin{array}{c}\mathbf{0 . 2 8 5} \\
(0.114)\end{array}$ \\
\hline $\begin{array}{l}\text { Displaced and Mean Quarterly } \\
\text { Earnings } 1974-79<25 \text { th Percentile }\end{array}$ & $\begin{array}{c}\mathbf{0 . 1 3 2} \\
(0.043)\end{array}$ & $\begin{array}{l}\mathbf{0 . 0 2 7} \\
(0.070)\end{array}$ & $\begin{array}{l}\mathbf{0 . 2 2 5} \\
(0.049)\end{array}$ \\
\hline $\begin{array}{l}\text { Displaced and Mean Qrt. Earnings } \\
\text { 1974-79 > 25th Perc. and }<\text { Median }\end{array}$ & $\begin{array}{c}\mathbf{0 . 1 5 3} \\
(0.040)\end{array}$ & $\begin{array}{c}\mathbf{0 . 0 2 8} \\
(0.070)\end{array}$ & $\begin{array}{c}\mathbf{0 . 1 9 8} \\
(0.044)\end{array}$ \\
\hline $\begin{array}{l}\text { Displaced and Mean Qrt. Earnings } \\
\text { 1974-79 > Median and < 75th Perc. }\end{array}$ & $\begin{array}{c}\mathbf{0 . 1 7 2} \\
(0.040)\end{array}$ & $\begin{array}{c}\mathbf{0 . 1 0 0} \\
(0.068)\end{array}$ & $\begin{array}{c}\mathbf{0 . 2 4 5} \\
(0.042)\end{array}$ \\
\hline $\begin{array}{l}\text { Displaced and Mean Qrt. Earnings } \\
1974-79>75 \text { th Perc. }\end{array}$ & $\begin{array}{c}\mathbf{0 . 1 0 1} \\
(0.043)\end{array}$ & $\begin{array}{c}\mathbf{0 . 1 4 4} \\
(0.070)\end{array}$ & $\begin{array}{c}\mathbf{0 . 1 2 8} \\
(0.047)\end{array}$ \\
\hline Displaced in West Pennsylvania & $\begin{array}{c}\mathbf{0 . 0 9 5} \\
(0.037)\end{array}$ & $\begin{array}{c}\mathbf{0 . 0 2 7} \\
(0.060)\end{array}$ & $\begin{array}{c}\mathbf{0 . 1 9 1} \\
(0.045)\end{array}$ \\
\hline Displaced in East Pennsylvania & $\begin{array}{c}\mathbf{0 . 1 8 0} \\
(0.034)\end{array}$ & $\begin{array}{c}\mathbf{0 . 1 1 5} \\
(0.053)\end{array}$ & $\begin{array}{c}\mathbf{0 . 2 0 2} \\
(0.040)\end{array}$ \\
\hline
\end{tabular}

Notes: Samples are workers born 1920-59 in stable jobs from 1974-79 with an employer of over 50 workers. Dependent variable is the log odds of death. Entries are coefficient estimates from the logitmodel. All models include year fixed effects, industry fixed effects, a quartic in age, the log of average quarterly earnings in 1974-79, and the log of the standard deviation of quarterly earnings in 1974-79. 
Table 8: Impact of Job Displacement at Mass-Layoff on Life Expectancy, Alternative Samples (May Up

\begin{tabular}{|c|c|c|c|c|c|}
\hline Data & Model & Age & $\begin{array}{c}\text { Life } \\
\text { Expectancy } \\
\text { given not } \\
\text { Displaced }\end{array}$ & $\begin{array}{c}\text { Life } \\
\text { Expectancy } \\
\text { given } \\
\text { Displaced }\end{array}$ & $\begin{array}{l}\text { Lost Years of } \\
\text { Life due } \\
\text { to Job } \\
\text { Displacement }\end{array}$ \\
\hline (1) Stable job 1974-79 & & 30 & 75.86 & 73.79 & 2.06 \\
\hline No restrictions on & & 35 & 75.47 & 73.38 & 2.09 \\
\hline earnings $1980-86$ & Displacement by age & 40 & 75.64 & 74.21 & 1.43 \\
\hline non mass layoff & at displacement in 10 & 45 & 75.90 & 74.40 & 1.49 \\
\hline separators included & $\begin{array}{l}\text { year increments plus } \\
\text { five time since }\end{array}$ & 50 & 76.28 & 75.30 & 0.98 \\
\hline Estimated 1980-2002 & displacment categories & 55 & 76.85 & 75.74 & 1.11 \\
\hline (2) Stable job 1974-79 & Displacement by age & 30 & 75.96 & 74.21 & 1.75 \\
\hline No restrictions on & at displacement in 10 & 35 & 76.07 & 74.34 & 1.74 \\
\hline earnings 1980-86 & year increments & 40 & 76.25 & 75.23 & 1.02 \\
\hline non mass layoff & & 45 & 76.51 & 75.51 & 1.00 \\
\hline separators included & & 50 & 76.90 & 75.74 & 1.16 \\
\hline Estimated 1987-2002 & & 55 & 77.46 & 76.36 & 1.10 \\
\hline (3) Stable job 1974-79 & Displacement by age & 30 & 76.21 & 74.60 & 1.61 \\
\hline earnings three years & at displacement in 10 & 35 & 76.32 & 74.73 & 1.59 \\
\hline $1980-86$ & year increments & 40 & 76.50 & 75.42 & 1.07 \\
\hline non mass layoff & & 45 & 76.76 & 75.71 & 1.05 \\
\hline separators included & & 50 & 77.15 & 76.05 & 1.10 \\
\hline Estimated 1987-2002 & & 55 & 77.71 & 76.67 & 1.04 \\
\hline (4) Stable job 1974-79 & Displacement by age & 30 & 76.47 & 74.75 & 1.72 \\
\hline earnings every year & at displacement in 10 & 35 & 76.57 & 74.87 & 1.70 \\
\hline $1980-86$ & year increments & 40 & 76.73 & 75.87 & 0.86 \\
\hline no non mass layoff & & 45 & 76.98 & 76.13 & 0.84 \\
\hline separators & & 50 & 77.34 & 76.41 & 0.93 \\
\hline Estimated 1987-2002 & & 55 & 77.87 & 76.99 & 0.89 \\
\hline
\end{tabular}

Notes: All models include log of mean earnings, log of standard deviation of log quarterly earnings, 1-digit industry dummies, and a linear age effect. The numbers are based on a linear extrapolation in age for cohorts still alive. 
Table 9: Impact of Mass-Layoff on Career Outcomes

Panel A: stable job 1974-79; born 1930-59; earnings every year through 1991 (17,576 workers)

\begin{tabular}{|c|c|c|c|c|}
\hline \multirow[b]{2}{*}{ Outcome Measure } & \multicolumn{4}{|c|}{ Years since displacement } \\
\hline & -1 to -2 & 0 to 2 & 3 to 6 & 7 to 11 \\
\hline ln average earnings & $\begin{array}{l}\mathbf{- 0 . 0 4 7} \\
(0.004)\end{array}$ & $\begin{array}{l}-\mathbf{0 . 4 5 9} \\
(0.004)\end{array}$ & $\begin{array}{l}\mathbf{- 0 . 2 6 6} \\
(0.004)\end{array}$ & $\begin{array}{c}\mathbf{- 0 . 1 9 5} \\
(0.005)\end{array}$ \\
\hline Quarterly employment probability & $\begin{array}{l}-\mathbf{0 . 0 0 2} \\
(0.001)\end{array}$ & $\begin{array}{l}-\mathbf{0 . 0 6 9} \\
(0.001)\end{array}$ & $\begin{array}{l}-\mathbf{0 . 0 1 3} \\
(0.001)\end{array}$ & $\begin{array}{c}\mathbf{0 . 0 0 2} \\
(0.001)\end{array}$ \\
\hline Absolute value of earnings growth & $\begin{array}{c}\mathbf{0 . 0 0 8} \\
(0.003)\end{array}$ & $\begin{array}{c}\mathbf{0 . 3 0 9} \\
(0.003)\end{array}$ & $\begin{array}{c}\mathbf{0 . 0 6 5} \\
(0.003)\end{array}$ & $\begin{array}{r}-\mathbf{0 . 0 0 8} \\
(0.004)\end{array}$ \\
\hline Transitions to nonemployment per year & $\begin{array}{c}\mathbf{0 . 0 0 3} \\
(0.001)\end{array}$ & $\begin{array}{c}\mathbf{0 . 0 3 6} \\
(0.001)\end{array}$ & $\begin{array}{c}\mathbf{0 . 0 0 7} \\
(0.001)\end{array}$ & $\begin{array}{c}\mathbf{0 . 0 0 0} \\
(0.001)\end{array}$ \\
\hline Probability of job change in year & & $\begin{array}{c}\mathbf{0 . 4 0 4} \\
(0.002)\end{array}$ & $\begin{array}{c}\mathbf{0 . 1 2 4} \\
(0.002)\end{array}$ & $\begin{array}{c}\mathbf{0 . 0 5 7} \\
(0.003)\end{array}$ \\
\hline Probability of industry change in year & & $\begin{array}{c}\mathbf{0 . 2 5 3} \\
(0.003)\end{array}$ & $\begin{array}{c}\mathbf{0 . 0 2 6} \\
(0.003)\end{array}$ & $\begin{array}{l}-\mathbf{- 0 . 0 2 4} \\
(0.004)\end{array}$ \\
\hline Probability of county of employer change in year & & $\begin{array}{c}\mathbf{0 . 1 9 5} \\
(0.003)\end{array}$ & $\begin{array}{c}\mathbf{0 . 0 2 8} \\
(0.002)\end{array}$ & $\begin{array}{l}-\mathbf{- 0 . 0 1 0} \\
(0.003)\end{array}$ \\
\hline
\end{tabular}

Panel B: stable job 1974-79; born 1920-59; earnings every year 1974-79 and 1987-91 (24,520 workers)

Years since displacement

Outcome Measure

ln average earnings

Quarterly employment probability

Absolute value of earnings growth

Transitions to nonemployment per year

Probability of job change in year

Probability of industry change in year

Probability of county of employer change in year

$\begin{array}{llll}-1 \text { to }-2 & 0 \text { to } 2 & 3 \text { to } 6 & 7 \text { to } 11\end{array}$

$\begin{array}{cccc}\mathbf{- 0 . 0 1 5} & \mathbf{- 0 . 4 5 4} & \mathbf{- 0 . 3 2 5} & \mathbf{- 0 . 2 4 0} \\ (0.003) & (0.004) & (0.003) & (0.004) \\ \mathbf{0 . 0 1 1} & \mathbf{- 0 . 1 2 3} & \mathbf{- 0 . 0 4 3} & \mathbf{0 . 0 0 9} \\ (0.001) & (0.001) & (0.001) & (0.001) \\ \mathbf{- 0 . 0 0 6} & \mathbf{0 . 3 0 5} & \mathbf{0 . 0 9 7} & \mathbf{0 . 0 1 3} \\ (0.003) & (0.003) & (0.003) & (0.004) \\ \mathbf{0 . 0 0 3} & \mathbf{0 . 0 4 0} & \mathbf{0 . 0 1 0} & \mathbf{0 . 0 0 4} \\ (0.000) & (0.001) & (0.001) & (0.001) \\ & \mathbf{0 . 4 0 3} & \mathbf{0 . 1 4 1} & \mathbf{0 . 0 6 7} \\ & (0.002) & (0.002) & (0.002) \\ & \mathbf{0 . 2 7 2} & \mathbf{0 . 0 5 7} & \mathbf{- 0 . 0 2 2} \\ & (0.002) & (0.002) & (0.003) \\ & \mathbf{0 . 2 2 1} & \mathbf{0 . 0 5 3} & \mathbf{- 0 . 0 2 0} \\ & (0.002) & (0.002) & (0.003)\end{array}$


Table 10: Mortality Increases by Career Outcomes after Job Loss at Individual and Cell Level

\begin{tabular}{|c|c|c|c|c|c|}
\hline \multirow[b]{2}{*}{ Model } & \multirow{2}{*}{$\begin{array}{l}\text { Coefficient on Covariate in Logit } \\
\text { Model of Annual Mortality } \\
\text { Hazard: }\end{array}$} & \multicolumn{2}{|c|}{$\begin{array}{c}\text { No Work Restriction, } \\
\text { Cohort }>1930 \\
\end{array}$} & \multicolumn{2}{|c|}{$\begin{array}{c}\text { Work Every Year 1980-1986, } \\
\text { Cohort }>1930\end{array}$} \\
\hline & & All Workers & $\begin{array}{c}\text { Only } \\
\text { Displaced }\end{array}$ & All Workers & $\begin{array}{c}\text { Only } \\
\text { Displaced }\end{array}$ \\
\hline \multirow{5}{*}{ (2) } & $\begin{array}{l}\text { Dummy for Job Loss During } \\
\text { Mass-Layoff }\end{array}$ & $\begin{array}{l}-\mathbf{0 . 0 1 3} \\
(0.046)\end{array}$ & - & $\begin{array}{c}\mathbf{0 . 0 1 0} \\
(0.063)\end{array}$ & - \\
\hline & $\begin{array}{l}\text { Percent Change in Long-Term } \\
\text { Average Earnings }\end{array}$ & $\begin{array}{l}-1.169 \\
(0.069)\end{array}$ & $\begin{array}{l}-\mathbf{0 . 9 9 7} \\
(0.111)\end{array}$ & $\begin{array}{l}\mathbf{- 0 . 7 0 6} \\
(0.142)\end{array}$ & $\begin{array}{l}\mathbf{- 0 . 5 6 7} \\
(0.199)\end{array}$ \\
\hline & $\begin{array}{l}\text { Dummy for Job Loss During } \\
\text { Mass-Layoff }\end{array}$ & $\begin{array}{l}-\mathbf{0 . 0 7 3} \\
(0.059)\end{array}$ & $\begin{array}{l}-- \\
--\end{array}$ & $\begin{array}{l}-\mathbf{0 . 0 7 9} \\
(0.066)\end{array}$ & $\begin{array}{l}-- \\
--\end{array}$ \\
\hline & $\begin{array}{l}\text { Change in Individual Long-Term } \\
\text { Average Earnings }\end{array}$ & $\begin{array}{l}-0.345 \\
(0.111)\end{array}$ & $\begin{array}{l}-0.421 \\
(0.188)\end{array}$ & $\begin{array}{l}-\mathbf{0 . 4 7 9} \\
(0.152)\end{array}$ & $\begin{array}{l}\mathbf{- 0 . 4 2 2} \\
(0.231)\end{array}$ \\
\hline & $\begin{array}{l}\text { At Least One Transition to Non- } \\
\text { Employment }\end{array}$ & $\begin{array}{c}\mathbf{0 . 0 6 5} \\
(0.059)\end{array}$ & $\begin{array}{l}-\mathbf{0 . 0 9 5} \\
(0.109)\end{array}$ & $\begin{array}{c}\mathbf{0 . 0 6 7} \\
(0.065)\end{array}$ & $\begin{array}{l}-\mathbf{0 . 0 7 6} \\
(0.112)\end{array}$ \\
\hline \multirow{2}{*}{\multicolumn{2}{|c|}{$\begin{array}{l}\text { Linear Probability Models: Average } \\
\text { Earnings Change Predicted by } \\
\text { Interaction of MLF and Cell-Effects }\end{array}$}} & \multicolumn{2}{|c|}{$\begin{array}{c}\text { No Work Restriction, } \\
\text { Cohort }>1930 \\
\end{array}$} & \multicolumn{2}{|c|}{$\begin{array}{c}\text { Work Every Year 1980-1986, } \\
\text { Cohort }>1930\end{array}$} \\
\hline & & $\begin{array}{l}\text { Individual } \\
\text { Level }\end{array}$ & Cell Level & $\begin{array}{l}\text { Individual } \\
\text { Level }\end{array}$ & Cell Level \\
\hline (3) & $\begin{array}{l}\text { Cells of Age in } 1979 \text { and Avg. } \\
\text { Earnings in 1974-79 }\end{array}$ & $\begin{array}{l}\mathbf{- 0 . 0 0 2 8} \\
(0.0001)\end{array}$ & $\begin{array}{l}\mathbf{- 0 . 0 0 3 0} \\
(0.0007)\end{array}$ & $\begin{array}{l}\mathbf{- 0 . 0 0 3 3} \\
(0.0003)\end{array}$ & $\begin{array}{l}\mathbf{- 0 . 0 0 2 1} \\
(0.0011)\end{array}$ \\
\hline (4) & $\begin{array}{l}\text { Cells of Age in } 1979 \text { and Industry } \\
\text { in } 1979\end{array}$ & $\begin{array}{l}\mathbf{- 0 . 0 0 2 8} \\
(0.0001)\end{array}$ & $\begin{array}{l}\mathbf{- 0 . 0 0 2 7} \\
(0.0007)\end{array}$ & $\begin{array}{l}\mathbf{- 0 . 0 0 3 3} \\
(0.0002)\end{array}$ & $\begin{array}{l}\mathbf{- 0 . 0 0 2 1} \\
(0.0012)\end{array}$ \\
\hline (5) & $\begin{array}{l}\text { Cells of Avg. Earnings in 1974-79 } \\
\text { and Industry in } 1979\end{array}$ & $\begin{array}{l}\mathbf{- 0 . 0 0 2 8} \\
(0.0001)\end{array}$ & $\begin{array}{l}\mathbf{- 0 . 0 0 2 5} \\
(0.0005)\end{array}$ & $\begin{array}{l}\mathbf{- 0 . 0 0 3 3} \\
(0.0003)\end{array}$ & $\begin{array}{l}\mathbf{- 0 . 0 0 1 3} \\
(0.0009)\end{array}$ \\
\hline (6) & $\begin{array}{l}\text { Cells of Avg. Age in } 1979 \text { and } \\
\text { Local Unemployment in } 1979\end{array}$ & $\begin{array}{l}\mathbf{- 0 . 0 0 2 8} \\
(0.0001)\end{array}$ & $\begin{array}{l}\mathbf{- 0 . 0 0 2 6} \\
(0.0005)\end{array}$ & $\begin{array}{l}\mathbf{- 0 . 0 0 3 3} \\
(0.0003)\end{array}$ & $\begin{array}{l}\mathbf{- 0 . 0 0 1 6} \\
(0.0010)\end{array}$ \\
\hline
\end{tabular}

Notes: The models in the first half of the table show coefficients for logit models of the annual hazard of death contr dummies, a quartic in age, pre-mass layoff career outcomes (log average quarterly earnings, log of standard deviation । number of quarters in non-employment, average quarterly growth in earnings, all measured from 1974-79), as well as from 1974-79 to 1987-91 (percent change in the standard deviation of log quarterly earnings, change in the average gt The models in the second half of the table report coefficients on linear probability models of the hazard of death con dummies, a quartic in age, pre-mass layoff career outcomes. 
Figure 1: Estimate of the Long-term Earnings Decline Due to Job Displacement at Mass-Layoffs Using Jacobson,Lalonde, and Sullivan (1993)'s Mass-Layoff Sample

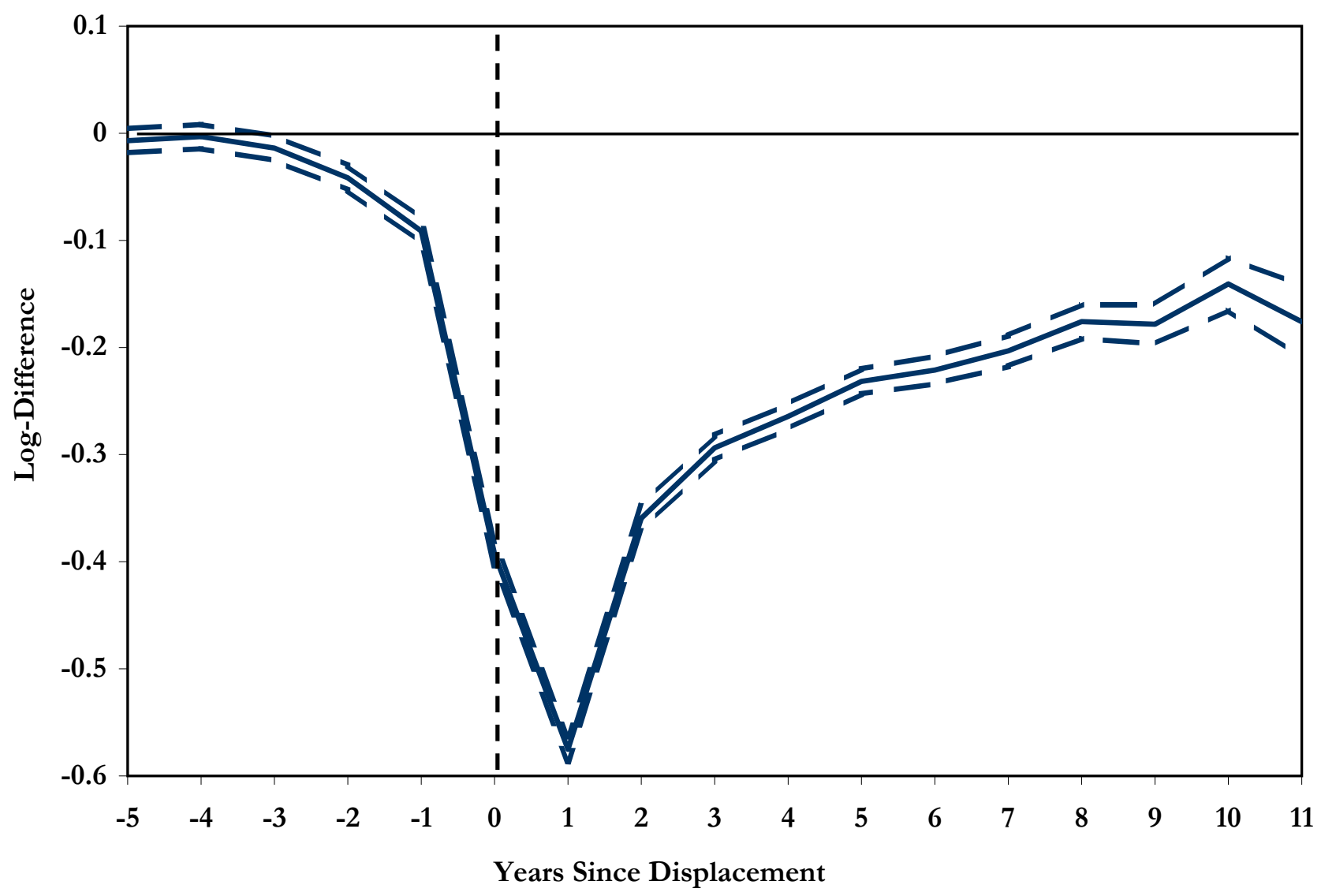

Notes: Solid line represent coefficient estimates of the interaction of year effects and displacement dummies in a regression model of log quarterly earnings including year fixed effects, person fixed effects, and a quartic for age. Two standard error bands are drawn around main effects. 
Figure 2: Percentage Effect of Job Displacement at Mass-Layoff on Mortality Rate by Time Since Layoff (Sample of Men in Stable Employment 1974-1979, Born 1930-1959)

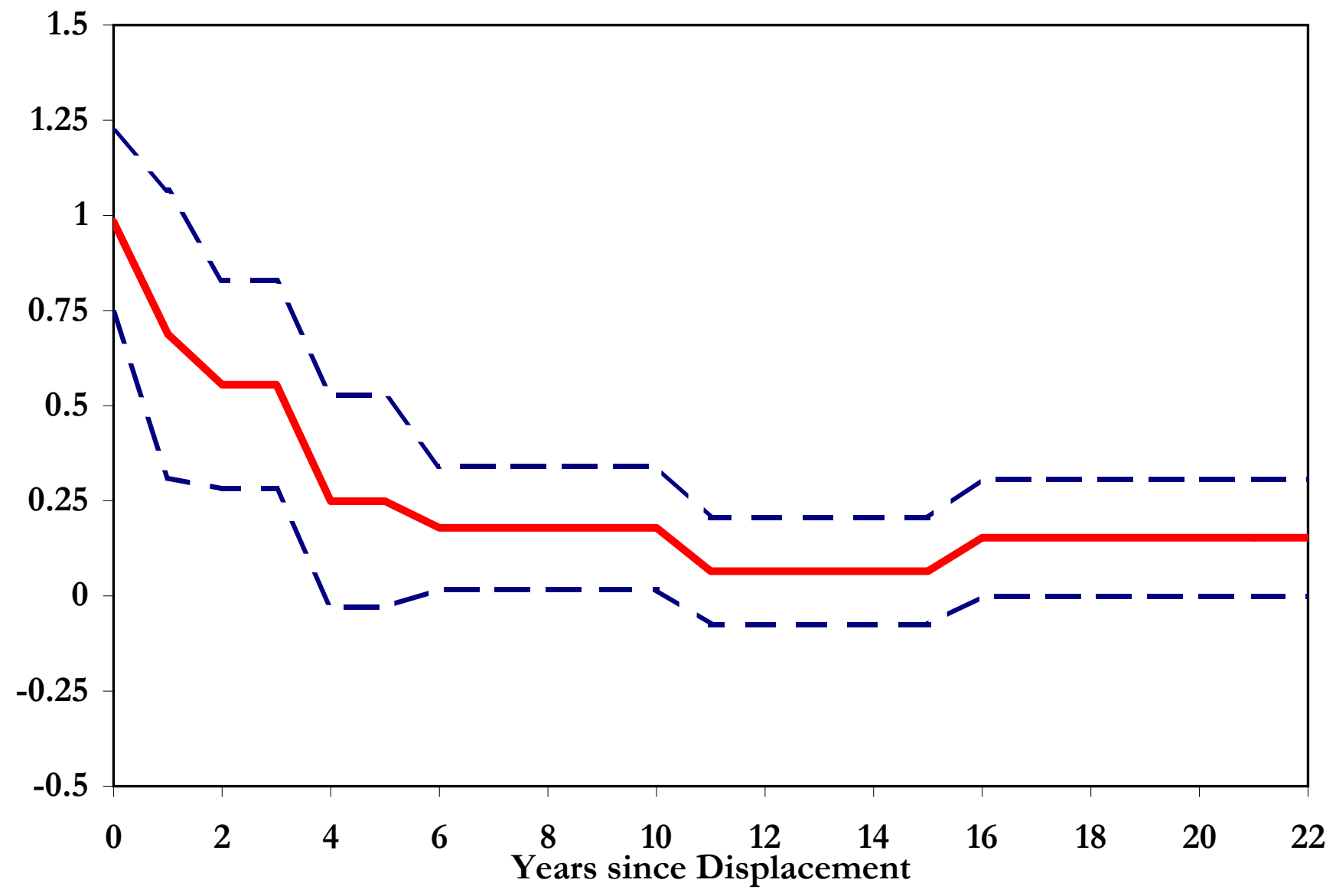

Notes: Solid line represents coefficients of log-odds model shown in Table 4, column (3). Dashed lines represent two-standard errors bands. 
Figure 3: Predicted Effects of Job Loss at Mass-Layoff on Mortality and Average Earnings on Mortality by Age

Panel A: Mortality by Mass-Layoff Status [Average Mean 1974-1979 Quarterly Earnings]

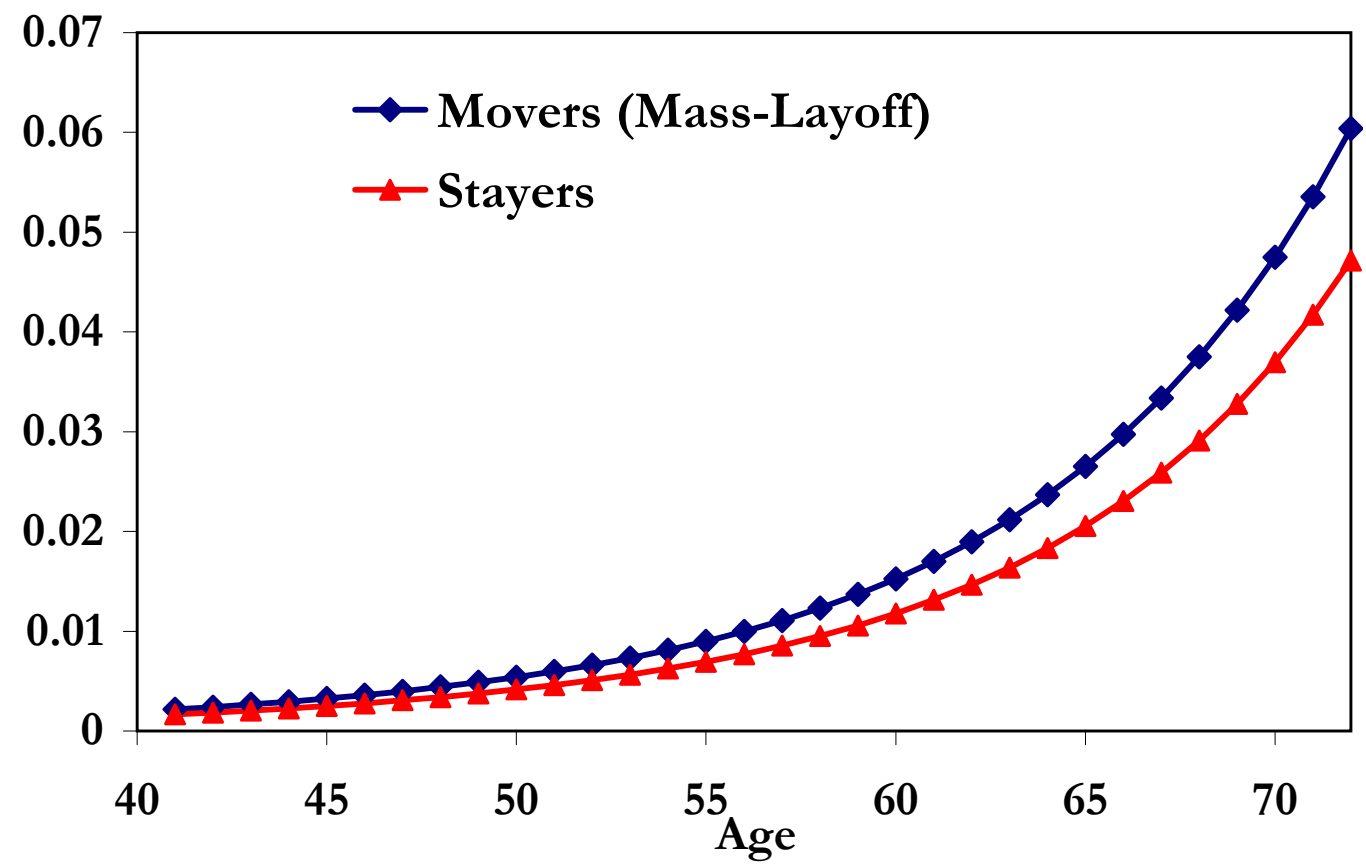

Panel B: Mortality by Average, 25th, 75th Percentile of Mean 1974-19 79 Quarterly Earnings

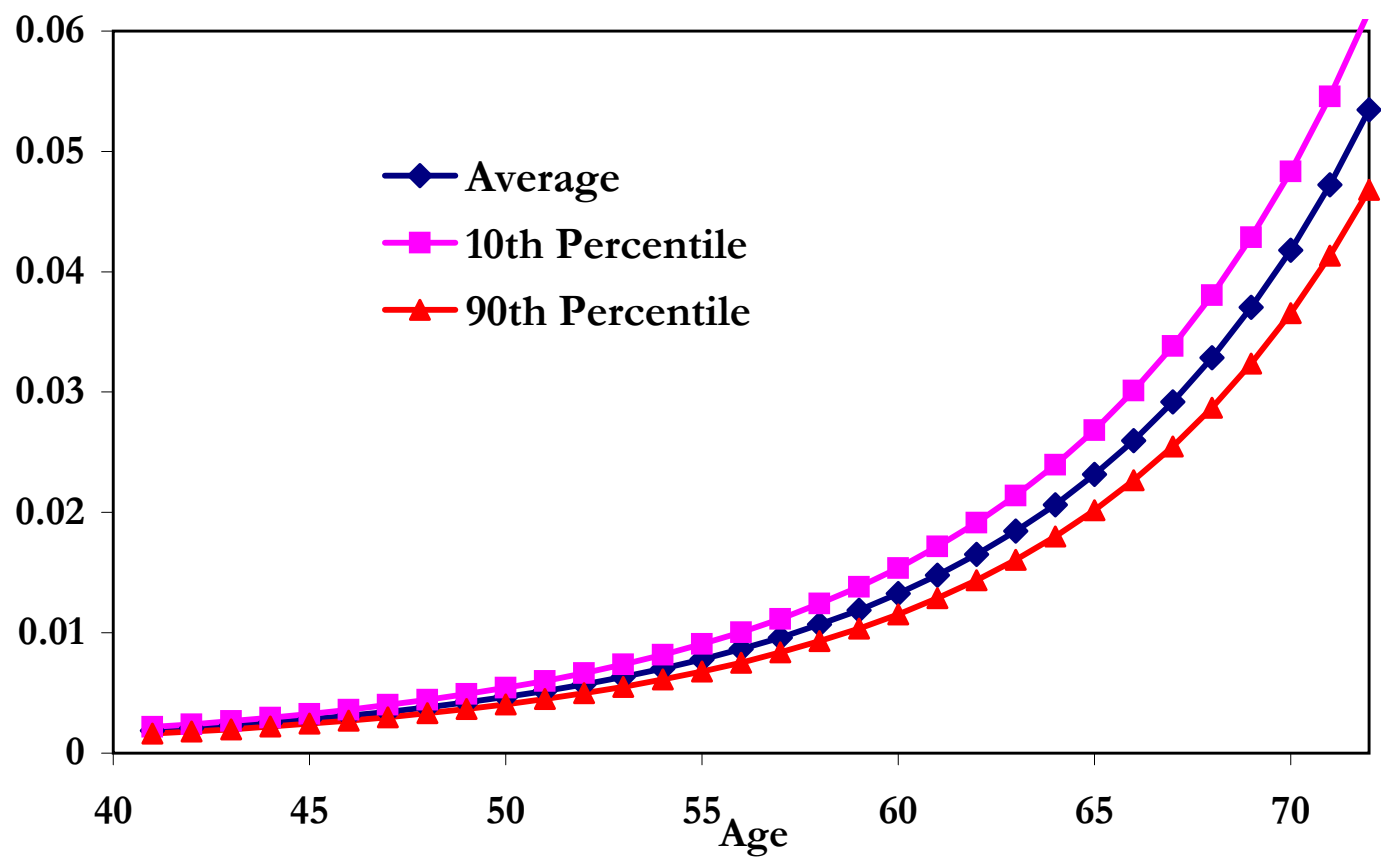


Figure 4: Mortality Gradient in Average 1974-1979 Earnings and Standard Deviation: Men in Stable Employment 1974-1986

Panel A: Correlation between Average Quarterly Earnings and Mortality, Alternative Specifications

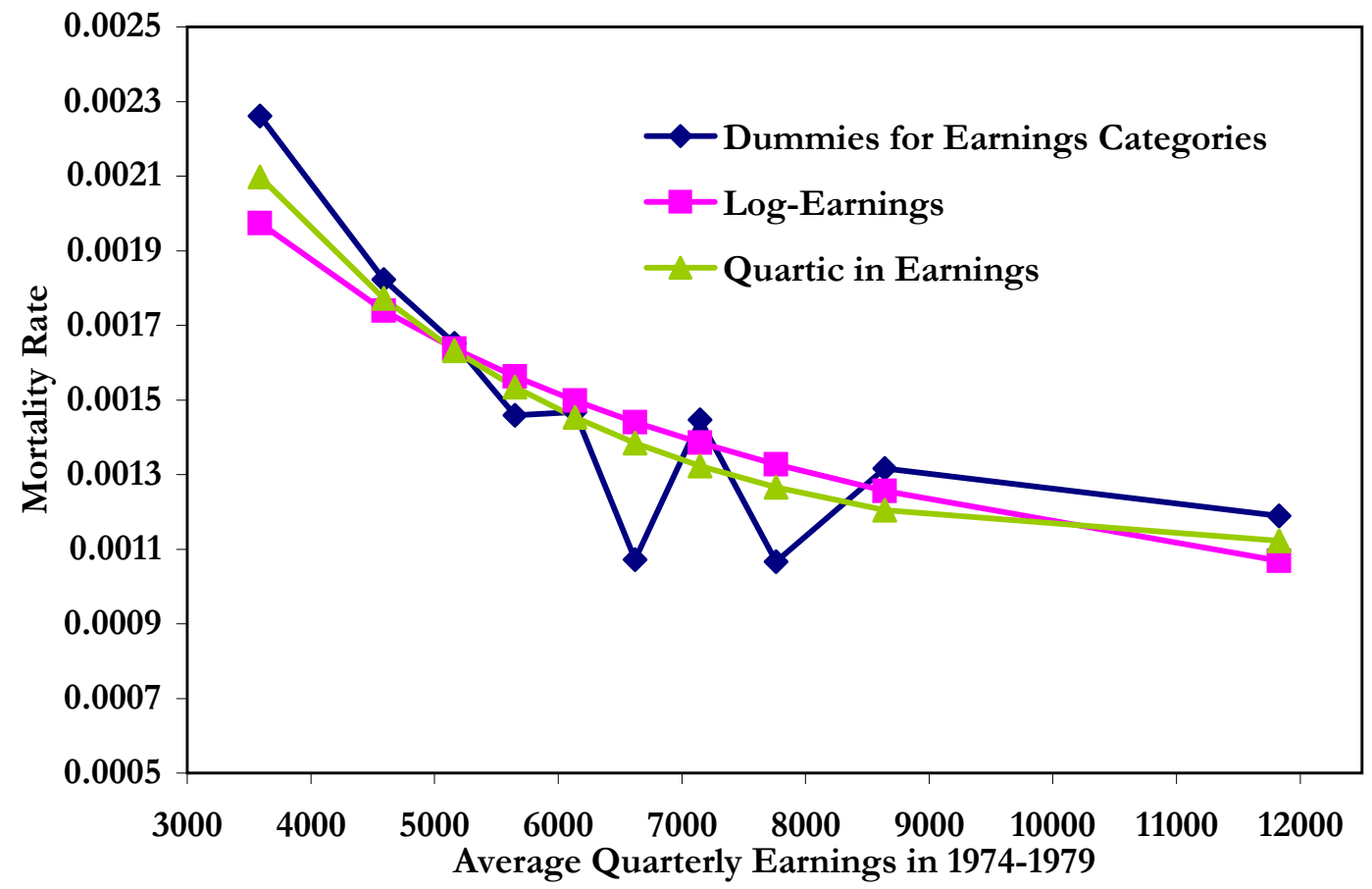

Panel B: Correlation between Standar Deviation of Log Quarterly Earnings and Mortality, Alternative Specifications

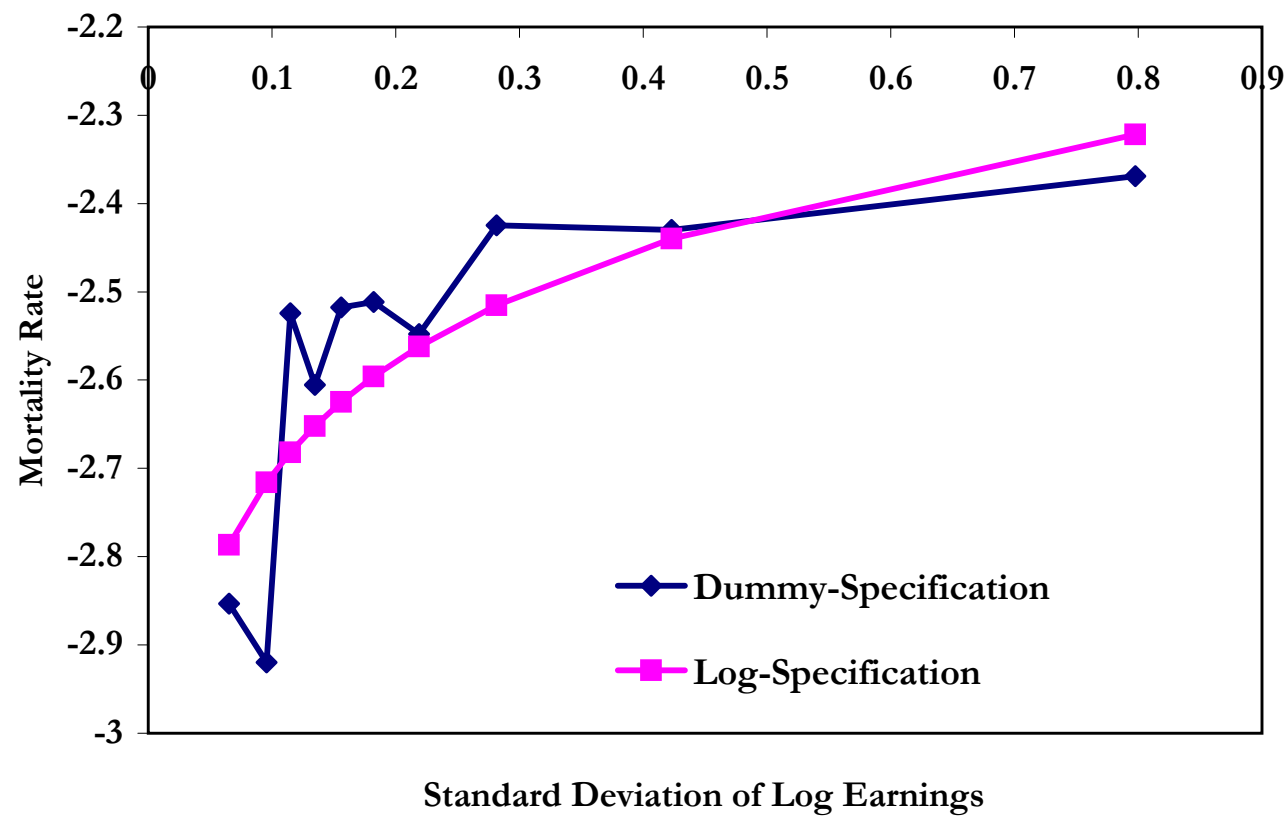


Figure 5: The Effect of Earnings Changes at Mass Layoff on Mortality at Individual Level and at Cell Level

Panel A: Differences in Mortality by Deciles of Changes in Average Earnings, Workers Born in 1920, Alternative Samples

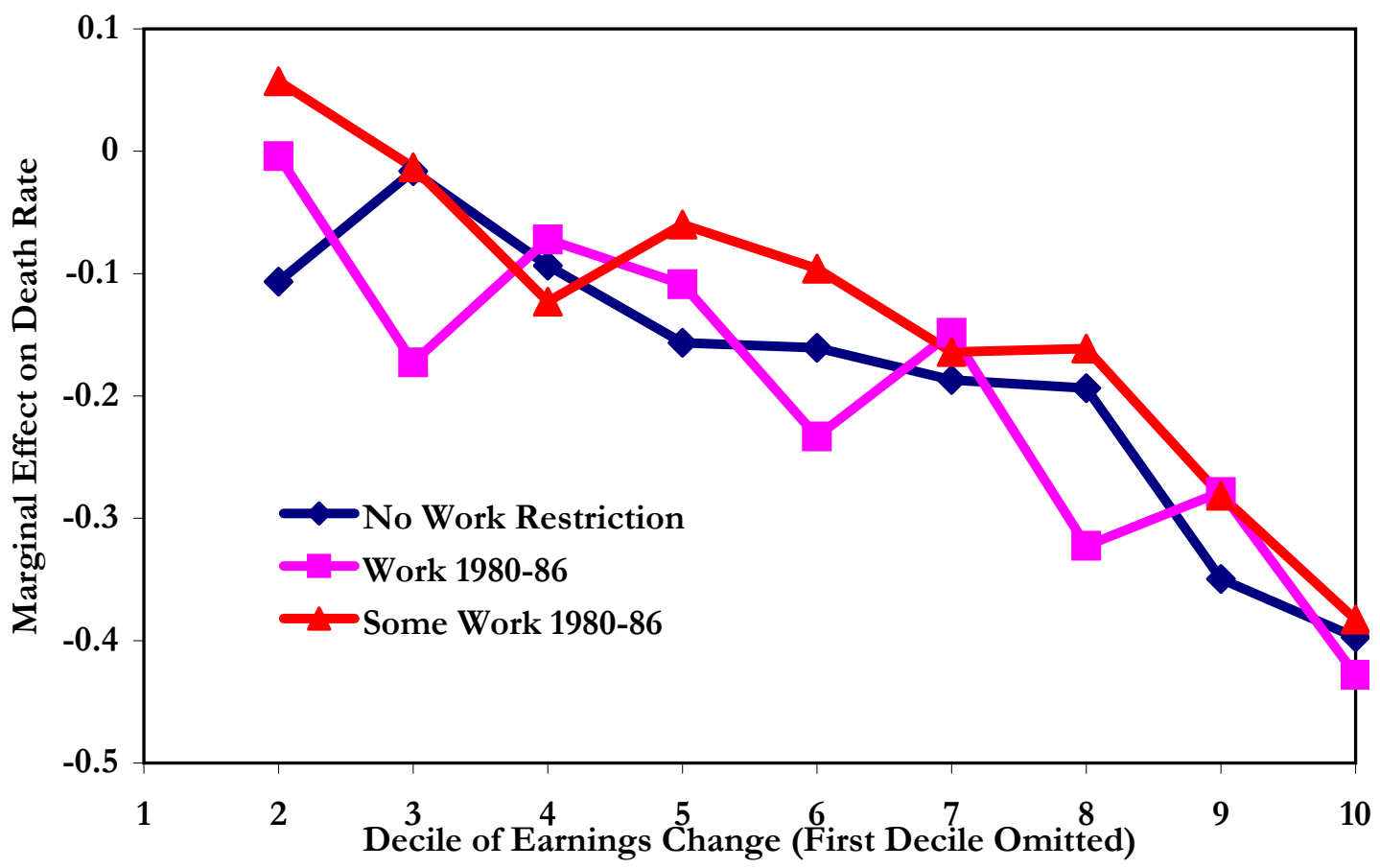

Notes: Coefficients on dummies for deciles of changes in average earnings from 1974-79 to 1980-86 in a logit model of death. Other variables include year effects, a quartic in age, and the average and standard deviation of earnings 1974-79.

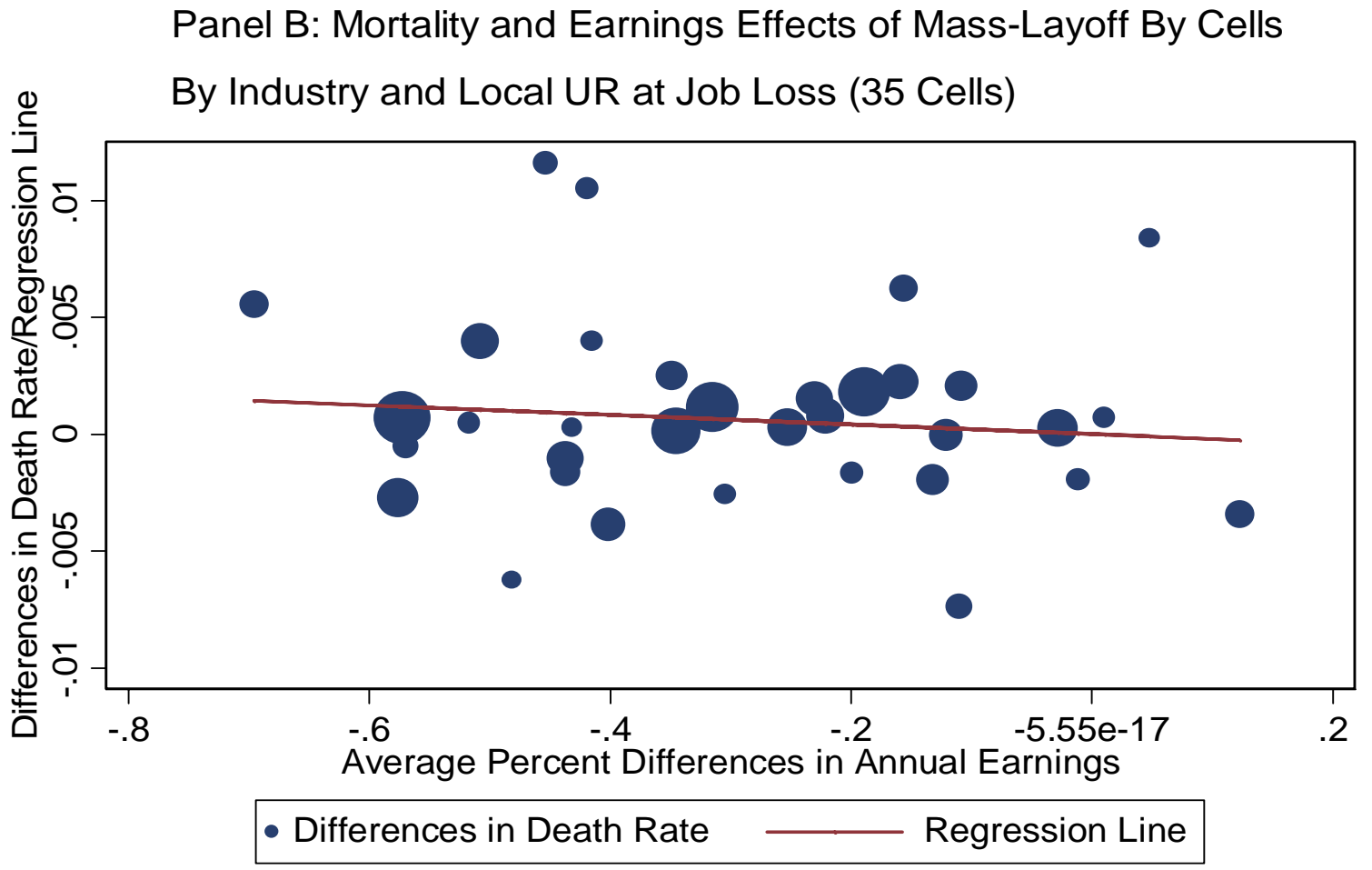

Notes: Birth Year $>=1930$, Stable Workers 
Figure 6: PDV Earnings Losses and Life-Expectancy By Five Year Age-Group, Alternative PDV Estimates

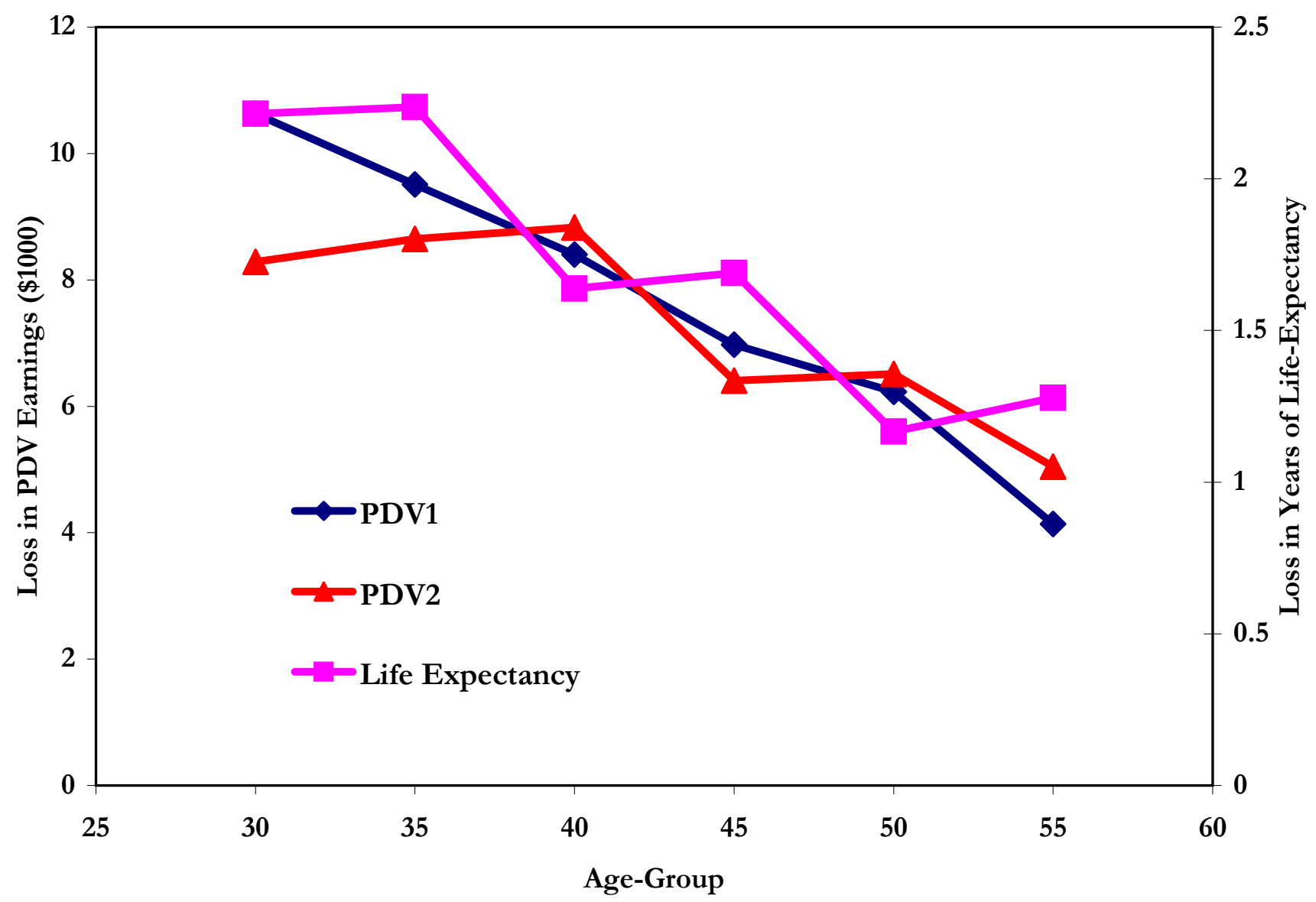

Notes: PDV 1 is based on 10-year age-interactions with job loss dummy, PDV 2 is based on 5-year interactions with job loss dummy. 
Appendix Table 1: Sample Statistics by Alternate Years and Samples for Workers in Stable Job 19741979 at Employer with at least 50 Employees

Panel A: Broad Sample (No Work Restriction 1980-1986)

\begin{tabular}{cccccccccc}
\hline $\begin{array}{c}\text { Year of } \\
\text { Follow- } \\
\text { Up }\end{array}$ & $\begin{array}{c}\text { Average } \\
\text { Age }\end{array}$ & Min. Age Max. Age & $\begin{array}{c}\text { Fraction } \\
\text { Age }>=60\end{array}$ & $\begin{array}{c}\text { Sample } \\
\text { Size }\end{array}$ & $\begin{array}{c}\text { Mortality } \\
\text { Rate }\end{array}$ & $\begin{array}{c}\text { Number } \\
\text { Dead }\end{array}$ & $\begin{array}{c}\text { Average } \\
\text { Quart. } \\
\text { Earnings } \\
\text { 1974-79 }\end{array}$ & $\begin{array}{c}\text { Fraction } \\
\text { Mass- } \\
\text { Layoff }\end{array}$ \\
\hline \hline 1981 & 39 & 22 & 51 & 0.00 & 21655 & 0.0021 & 45 & 6663 & 0.352 \\
1983 & 41 & 24 & 53 & 0.00 & 21567 & 0.0026 & 57 & 6663 & 0.351 \\
1985 & 43 & 26 & 55 & 0.00 & 21456 & 0.0028 & 60 & 6665 & 0.350 \\
1987 & 45 & 28 & 57 & 0.00 & 21323 & 0.0040 & 86 & 6664 & 0.348 \\
1989 & 47 & 30 & 59 & 0.00 & 21158 & 0.0036 & 76 & 6664 & 0.347 \\
1991 & 49 & 32 & 61 & 0.09 & 20986 & 0.0041 & 87 & 6663 & 0.347 \\
1993 & 51 & 34 & 63 & 0.16 & 20788 & 0.0059 & 122 & 6664 & 0.346 \\
1995 & 53 & 36 & 65 & 0.24 & 20534 & 0.0075 & 155 & 6664 & 0.346 \\
1997 & 55 & 38 & 67 & 0.31 & 20206 & 0.0084 & 169 & 6664 & 0.345 \\
1999 & 57 & 40 & 69 & 0.39 & 19894 & 0.0082 & 164 & 6667 & 0.345 \\
2001 & 59 & 42 & 71 & 0.46 & 19536 & 0.0111 & 216 & 6668 & 0.344 \\
\hline
\end{tabular}

Panel B: Original Mass-Layoff Sample (Some Earnings each Year 1980-86)

\begin{tabular}{cccccccccc}
\hline $\begin{array}{c}\text { Year of } \\
\begin{array}{c}\text { Follow- } \\
\text { Up }\end{array}\end{array}$ & $\begin{array}{c}\text { Average } \\
\text { Age }\end{array}$ & Min. Age Max. Age & $\begin{array}{c}\text { Fraction } \\
\text { Age }>=60\end{array}$ & $\begin{array}{c}\text { Sample } \\
\text { Size }\end{array}$ & $\begin{array}{c}\text { Mortality } \\
\text { Rate }\end{array}$ & $\begin{array}{c}\text { Number } \\
\text { Dead }\end{array}$ & $\begin{array}{c}\text { Average } \\
\text { Quart. } \\
\text { Earnings } \\
1974-79\end{array}$ & $\begin{array}{c}\text { Fraction } \\
\text { Mass- } \\
\text { Layoff }\end{array}$ \\
\hline \hline 1987 & 46 & 28 & 57 & 0.00 & 15532 & 0.003 & 53 & 6707 & 0.319 \\
1989 & 47 & 30 & 59 & 0.00 & 15430 & 0.003 & 53 & 6705 & 0.318 \\
1991 & 49 & 32 & 61 & 0.08 & 15309 & 0.004 & 57 & 6703 & 0.318 \\
1993 & 51 & 34 & 63 & 0.16 & 15182 & 0.006 & 87 & 6704 & 0.318 \\
1995 & 53 & 36 & 65 & 0.24 & 15009 & 0.007 & 111 & 6703 & 0.317 \\
1997 & 55 & 38 & 67 & 0.32 & 14777 & 0.008 & 116 & 6704 & 0.317 \\
1999 & 57 & 40 & 69 & 0.40 & 14570 & 0.008 & 119 & 6707 & 0.318 \\
2001 & 59 & 42 & 71 & 0.47 & 14323 & 0.010 & 147 & 6705 & 0.317 \\
\hline
\end{tabular}

Notes: Both sample include only male workers working at a stable job in 1974-1979 at firms with at least 50 employees in 1979. The mass-layoff sample in Panel B further requires some employment every year 1980-86 and only includes workers that either experience a mass layoff in the period 1980-86 or who remain with the present employer for that period. Both samples limit workers to birth cohorts 1930 to 1959. Further details on sample specifications in the text. 
Appendix Table 2: Sample Statistics by Alternate Years and Samples for Workers in Stable Job 1974-1979 at Employer with at least 50 Employees

Panel A: Broad Sample (No Work Restriction 1980-1986)

\begin{tabular}{ccccccccc}
\hline & \multicolumn{3}{c}{ Absolute Difference } & \multicolumn{3}{c}{ Percent Change to Baseline } \\
\hline Age & Average & 25th & 50 th & 75th & Average & 25th & 50 th & 75 th \\
\hline 40 & 0.0002 & 0.0002 & 0.0002 & 0.0002 & 0.13 & 0.12 & 0.13 & 0.11 \\
50 & 0.0004 & 0.0005 & 0.0004 & 0.0004 & 0.12 & 0.14 & 0.13 & 0.11 \\
60 & 0.0013 & 0.0014 & 0.0013 & 0.0013 & 0.13 & 0.13 & 0.13 & 0.11 \\
70 & 0.0036 & 0.0038 & 0.0036 & 0.0034 & 0.13 & 0.13 & 0.14 & 0.11 \\
\hline
\end{tabular}

Notes: Probabilities predicted using coefficients from the logit model of row A, column 1 in Table 3.

Panel B: Fitted Probability of Death by Age and Earnings Groups

\begin{tabular}{ccccccccc}
\hline & \multicolumn{7}{c}{ Mean Quarterly $1974-79$ Earnings } & 25th \\
\cline { 2 - 7 } Age & Average & 10th & 25th & 50th & 75th & 90th & minus \\
\cline { 2 - 7 } & $\$ 6,416$ & $\$ 4,314$ & $\$ 5,257$ & $\$ 6,451$ & $\$ 7,828$ & $\$ 9,370$ & 75th \\
\hline 40 & 0.0016 & 0.0016 & 0.0017 & 0.0015 & 0.0018 & 0.0014 & -0.0001 \\
50 & 0.0034 & 0.0034 & 0.0036 & 0.0032 & 0.0038 & 0.003 & -0.0002 \\
60 & 0.0104 & 0.0104 & 0.0111 & 0.0098 & 0.0117 & 0.0093 & -0.0006 \\
70 & 0.0282 & 0.0281 & 0.0299 & 0.0264 & 0.0317 & 0.0252 & -0.0018 \\
70 minus & & & & & & & \\
40 & 0.0266 & 0.0265 & 0.0282 & 0.0249 & 0.0299 & 0.0238 & \\
\hline
\end{tabular}

Notes: Probabilities predicted using coefficients from the logit model of row 1 and column 1 in Appendix Table 5. 
Appendix Table 3: Mortality Rates in Different Periods by Displacement Status

\section{Panel A: Work Every Year 1980-86}

\begin{tabular}{|c|c|c|c|c|c|c|}
\hline & All Workers & $\begin{array}{c}\text { Same Firm } \\
1974-86 \\
\end{array}$ & $\begin{array}{c}\text { Non-Mass- } \\
\text { Layoff } \\
\text { Separators }\end{array}$ & $\begin{array}{c}\text { Displaced } \\
30 \%-60 \% \\
\text { Below Peak } \\
\end{array}$ & $\begin{array}{c}\text { Displaced } \\
60 \%-90 \% \\
\text { Below Peak } \\
\end{array}$ & $\begin{array}{c}\text { Displaced } \\
\text { Greater Than } \\
\text { 90\% Below } \\
\text { Peak }\end{array}$ \\
\hline $87-02$ & $\begin{array}{r}5.716 \\
(0.154) \\
\end{array}$ & $\begin{array}{r}5.502 \\
(0.195) \\
\end{array}$ & $\begin{array}{r}5.688 \\
(0.429) \\
\end{array}$ & $\begin{array}{r}5.727 \\
(0.453) \\
\end{array}$ & $\begin{array}{c}6.402 \\
(0.506) \\
\end{array}$ & $\begin{array}{r}6.875 \\
(0.743) \\
\end{array}$ \\
\hline $87-91$ & $\begin{array}{c}3.607 \\
(0.203)\end{array}$ & $\begin{array}{c}3.348 \\
(0.252)\end{array}$ & $\begin{array}{c}3.381 \\
(0.548)\end{array}$ & $\begin{array}{c}3.743 \\
(0.606)\end{array}$ & $\begin{array}{c}4.723 \\
(0.718)\end{array}$ & $\begin{array}{l}4.630 \\
(1.008)\end{array}$ \\
\hline $92-96$ & $\begin{array}{c}6.539 \\
(0.252)\end{array}$ & $\begin{array}{c}6.336 \\
(0.320)\end{array}$ & $\begin{array}{c}6.386 \\
(0.695)\end{array}$ & $\begin{array}{c}6.749 \\
(0.752)\end{array}$ & $\begin{array}{c}7.255 \\
(0.824)\end{array}$ & $\begin{array}{c}7.381 \\
(1.178)\end{array}$ \\
\hline $97-02$ & $\begin{array}{c}8.221 \\
(0.315)\end{array}$ & $\begin{array}{c}7.729 \\
(0.394)\end{array}$ & $\begin{array}{c}9.405 \\
(0.941)\end{array}$ & $\begin{array}{c}7.354 \\
(0.876)\end{array}$ & $\begin{array}{l}9.346 \\
(1.047)\end{array}$ & $\begin{array}{l}10.735 \\
(1.592)\end{array}$ \\
\hline
\end{tabular}

Notes: Deaths per 1000 per year. Standard errors in parentheses. Displaced Workers left jobs in a year in which their former firms' employment was 30\% or more below its 1974-1979 peak. Nondisplaced workers remain at their 1979 firm through 1986.

\section{Panel B: No Work Restriction in 1980-86}

\begin{tabular}{|c|c|c|c|c|c|c|}
\hline & All Workers & $\begin{array}{c}\text { Same Firm } \\
1974-86\end{array}$ & $\begin{array}{c}\text { Non-Mass- } \\
\text { Layoff } \\
\text { Separators }\end{array}$ & $\begin{array}{c}\text { Displaced } \\
30 \%-60 \% \\
\text { Below Peak }\end{array}$ & $\begin{array}{c}\text { Displaced } \\
60 \%-90 \% \\
\text { Below Peak }\end{array}$ & $\begin{array}{c}\text { Displaced } \\
\text { Greater Than } \\
90 \% \text { Below } \\
\text { Peak }\end{array}$ \\
\hline 87-02 & $\begin{array}{c}6.185 \\
(0.146) \\
\end{array}$ & $\begin{array}{c}5.502 \\
(0.195) \\
\end{array}$ & $\begin{array}{c}6.525 \\
(0.367) \\
\end{array}$ & $\begin{array}{c}6.774 \\
(0.396) \\
\end{array}$ & $\begin{array}{c}6.828 \\
(0.434) \\
\end{array}$ & $\begin{array}{c}8.051 \\
(0.666) \\
\end{array}$ \\
\hline $80-86$ & $\begin{array}{c}2.465 \\
(0.128)\end{array}$ & 0.000 & $\begin{array}{c}6.525 \\
(0.367)\end{array}$ & $\begin{array}{c}5.537 \\
(0.492)\end{array}$ & $\begin{array}{c}3.410 \\
(0.422)\end{array}$ & $\begin{array}{c}1.477 \\
(0.395)\end{array}$ \\
\hline $87-91$ & $\begin{array}{c}4.008 \\
(0.194)\end{array}$ & $\begin{array}{c}3.348 \\
(0.252)\end{array}$ & $\begin{array}{c}4.083 \\
(0.480)\end{array}$ & $\begin{array}{c}4.517 \\
(0.535)\end{array}$ & $\begin{array}{c}4.987 \\
(0.613)\end{array}$ & $\begin{array}{c}5.874 \\
(0.938)\end{array}$ \\
\hline $92-96$ & $\begin{array}{c}6.981 \\
(0.237)\end{array}$ & $\begin{array}{c}6.336 \\
(0.320)\end{array}$ & $\begin{array}{c}7.244 \\
(0.591)\end{array}$ & $\begin{array}{c}7.661 \\
(0.645)\end{array}$ & $\begin{array}{c}7.605 \\
(0.700)\end{array}$ & $\begin{array}{c}8.584 \\
(1.052)\end{array}$ \\
\hline $97-02$ & $\begin{array}{c}8.699 \\
(0.296)\end{array}$ & $\begin{array}{c}7.729 \\
(0.394)\end{array}$ & $\begin{array}{c}9.957 \\
(0.776)\end{array}$ & $\begin{array}{c}8.656 \\
(0.768)\end{array}$ & $\begin{array}{c}9.975 \\
(0.899)\end{array}$ & $\begin{array}{l}10.717 \\
(1.322)\end{array}$ \\
\hline
\end{tabular}

Notes: Deaths per 1000 per year. Standard errors in parentheses. Displaced Workers left jobs in a year in which their former firms' employment was 30\% or more below its 1974-1979 peak. 
Appendix Table 4: Effect of Mass-Layoff on Mortality by Earnings Loss at Job Loss and Employment Status in Displacement Period

\begin{tabular}{|c|c|c|c|c|c|c|c|c|c|c|}
\hline & \multicolumn{5}{|c|}{ No Work Restriction, Birth Year $>1930$} & \multicolumn{5}{|c|}{ No Work Restriction, Birth Year $>1920$} \\
\hline & (1) & $(2)$ & (3) & (4) & (5) & (6) & (7) & (8) & (9) & (10) \\
\hline Log Average Earnings 1974-79 & $\begin{array}{l}-0.448 \\
(0.032)\end{array}$ & $\begin{array}{l}-0.491 \\
(0.059)\end{array}$ & $\begin{array}{l}-0.488 \\
(0.059)\end{array}$ & $\begin{array}{l}-0.471 \\
(0.058)\end{array}$ & $\begin{array}{l}-0.471 \\
(0.058)\end{array}$ & $\begin{array}{l}-0.505 \\
(0.057)\end{array}$ & $\begin{array}{l}-0.491 \\
(0.059)\end{array}$ & $\begin{array}{l}-0.488 \\
(0.059)\end{array}$ & $\begin{array}{l}-0.471 \\
(0.058)\end{array}$ & $\begin{array}{l}-0.471 \\
(0.058)\end{array}$ \\
\hline $\begin{array}{l}\% \text { Change in Long-Term Average } \\
\text { Earnings } 74-79 \text { vs. } 80-86(\Delta \mathrm{E})\end{array}$ & -- & $\begin{array}{l}-1.200 \\
(0.067)\end{array}$ & $\begin{array}{l}-0.891 \\
(0.156)\end{array}$ & $\begin{array}{l}-0.749 \\
(0.154)\end{array}$ & $\begin{array}{l}-0.754 \\
(0.155)\end{array}$ & - & $\begin{array}{l}-1.200 \\
(0.067)\end{array}$ & $\begin{array}{l}-0.891 \\
(0.156)\end{array}$ & $\begin{array}{l}-0.749 \\
(0.154)\end{array}$ & $\begin{array}{l}-0.754 \\
(0.155)\end{array}$ \\
\hline $\begin{array}{l}\text { Dummy for Job Loss During Mass- } \\
\text { Layoff (MLF) }\end{array}$ & $\begin{array}{c}0.140 \\
(0.026)\end{array}$ & $\begin{array}{l}-0.008 \\
(0.045)\end{array}$ & $\begin{array}{l}-0.143 \\
(0.076)\end{array}$ & $\begin{array}{c}0.105 \\
(0.158)\end{array}$ & $\begin{array}{c}0.119 \\
(0.162)\end{array}$ & $\begin{array}{c}0.262 \\
(0.043)\end{array}$ & $\begin{array}{l}-0.008 \\
(0.045)\end{array}$ & $\begin{array}{l}-0.143 \\
(0.076)\end{array}$ & $\begin{array}{c}0.105 \\
(0.158)\end{array}$ & $\begin{array}{c}0.119 \\
(0.162)\end{array}$ \\
\hline $\begin{array}{l}\text { Displaced at MLF and } \Delta E>25 \text { th } \\
\text { Perc. and }<\text { Median }\end{array}$ & -- & -- & $\begin{array}{c}0.034 \\
(0.111)\end{array}$ & $\begin{array}{l}-0.151 \\
(0.134)\end{array}$ & $\begin{array}{l}-0.153 \\
(0.134)\end{array}$ & - & -- & $\begin{array}{c}0.034 \\
(0.111)\end{array}$ & $\begin{array}{l}-0.151 \\
(0.134)\end{array}$ & $\begin{array}{l}-0.153 \\
(0.134)\end{array}$ \\
\hline $\begin{array}{l}\text { Displaced at MLF and } \Delta E>\text { Median } \\
\text { and }<75 \text { th Perc. }\end{array}$ & -- & - & $\begin{array}{c}0.270 \\
(0.124)\end{array}$ & $\begin{array}{c}0.055 \\
(0.166)\end{array}$ & $\begin{array}{c}0.054 \\
(0.166)\end{array}$ & - & - & $\begin{array}{c}0.270 \\
(0.124)\end{array}$ & $\begin{array}{c}0.055 \\
(0.166)\end{array}$ & $\begin{array}{c}0.054 \\
(0.166)\end{array}$ \\
\hline $\begin{array}{l}\text { Displaced at MLF and } \Delta E>75 \text { th } \\
\text { Perc. }\end{array}$ & -- & - & $\begin{array}{c}0.368 \\
(0.140)\end{array}$ & $\begin{array}{c}0.147 \\
(0.182)\end{array}$ & $\begin{array}{c}0.151 \\
(0.183)\end{array}$ & - & - & $\begin{array}{c}0.368 \\
(0.140)\end{array}$ & $\begin{array}{c}0.147 \\
(0.182)\end{array}$ & $\begin{array}{c}0.151 \\
(0.183)\end{array}$ \\
\hline $\begin{array}{l}\text { Dummy for 1-2 Quarters Non- } \\
\text { Employment }\end{array}$ & -- & - & -- & $\begin{array}{c}0.260 \\
(0.067)\end{array}$ & $\begin{array}{c}0.259 \\
(0.067)\end{array}$ & - & - & - & $\begin{array}{c}0.260 \\
(0.067)\end{array}$ & $\begin{array}{c}0.259 \\
(0.067)\end{array}$ \\
\hline $\begin{array}{l}\text { Dummy for More Than } 2 \text { Quarters } \\
\text { Non-Employment }\end{array}$ & -- & -- & -- & $\begin{array}{c}0.539 \\
(0.099)\end{array}$ & $\begin{array}{c}0.536 \\
(0.099)\end{array}$ & - & -- & $\begin{array}{l}-- \\
--\end{array}$ & $\begin{array}{c}0.539 \\
(0.099)\end{array}$ & $\begin{array}{c}0.536 \\
(0.099)\end{array}$ \\
\hline $\begin{array}{l}\text { Displaced at MLF and Non- } \\
\text { Employed for 1-2 Periods }\end{array}$ & - & - & - & $\begin{array}{l}-0.199 \\
(0.127)\end{array}$ & $\begin{array}{l}-0.197 \\
(0.127)\end{array}$ & - & - & - & $\begin{array}{l}-0.199 \\
(0.127)\end{array}$ & $\begin{array}{l}-0.197 \\
(0.127)\end{array}$ \\
\hline $\begin{array}{l}\text { Displaced at MLF and Non- } \\
\text { Employed More Than } 2 \text { Periods }\end{array}$ & - & - & - & $\begin{array}{l}-0.272 \\
(0.146)\end{array}$ & $\begin{array}{l}-0.266 \\
(0.146)\end{array}$ & - & - & $\begin{array}{l}-- \\
--\end{array}$ & $\begin{array}{l}-0.272 \\
(0.146)\end{array}$ & $\begin{array}{l}-0.266 \\
(0.146)\end{array}$ \\
\hline Dummies for Quartiles of $\Delta \mathrm{E}$ & Yes & Yes & Yes & Yes & Yes & Yes & Yes & Yes & Yes & Yes \\
\hline Controls for Age at Separation & -- & -- & -- & -- & Yes & -- & -- & -- & -- & Yes \\
\hline Observations & 681614 & 478664 & 478664 & 478664 & 478664 & 478664 & 478664 & 478664 & 478664 & 478664 \\
\hline
\end{tabular}

Notes: Samples are workers born 1920-59 in stable jobs from 1974-79 with an employer of over 50 workers. Dependent variable is the log odds of death. Entries are the coefficient estimates from the logit-model. All models include year fixed effects, industry fixed effects, a quartic in age, and the log of the standard deviation of quarterly earnings in 1974-79. All models also include three dummies for whether percent change in average earnings $(\Delta \mathrm{E})$ lies in between 25 th and 50 th percentile, 50th and 75 th percentile, or above 75 th percentile of the distribution in the population. None of the three dummy variables has an effect that is significantly different from zero. 
Appendix Table 5: Correlation of Mortality and Average Earnings, Sample With Work Every Year 1980-86

\begin{tabular}{|c|c|c|c|c|c|c|c|c|c|}
\hline & \multirow{2}{*}{\multicolumn{3}{|c|}{$\begin{array}{c}\text { Pooled Logit - Model } \\
\text { 1986-2002 }\end{array}$}} & \multicolumn{6}{|c|}{ Deaton and Paxson Models } \\
\hline & & & & \multicolumn{3}{|c|}{ Death 0-5 Years post 1986} & \multicolumn{3}{|c|}{ Death 5-10 Years post 1986} \\
\hline & All & Age $<60$ & Age $>60$ & All & Age $<60$ & Age $>60$ & All & Age $<60$ & Age $>60$ \\
\hline & (1) & (2) & (3) & (4) & (5) & (6) & (7) & (8) & (9) \\
\hline \multirow{2}{*}{$\begin{array}{l}\text { Basic Model [Average } 1974 \text { - } \\
1979 \text { Quarterly Earnings] }\end{array}$} & -0.509 & -0.514 & -0.506 & -0.309 & -0.591 & -0.309 & -0.515 & 0.093 & -0.936 \\
\hline & $(0.075)$ & $(0.105)$ & $(0.108)$ & $(0.179)$ & $(0.096)$ & $(0.179)$ & $(0.099)$ & $(0.990)$ & $(0.195)$ \\
\hline \multirow[t]{2}{*}{ With Birth Cohort-Controls } & -0.508 & -0.511 & -0.506 & -0.309 & -0.591 & -0.309 & -0.515 & 0.093 & -0.936 \\
\hline & $(0.075)$ & $(0.105)$ & $(0.108)$ & $(0.179)$ & $(0.096)$ & $(0.179)$ & $(0.099)$ & $(0.990)$ & $(0.195)$ \\
\hline \multirow[t]{2}{*}{ Single Year Earnings (1979) } & -0.388 & -0.347 & -0.433 & -0.326 & -0.437 & -0.326 & -0.377 & 0.057 & -0.746 \\
\hline & $(0.066)$ & $(0.092)$ & $(0.095)$ & $(0.155)$ & $(0.083)$ & $(0.155)$ & $(0.086)$ & $(0.925)$ & $(0.174)$ \\
\hline \multirow{2}{*}{$\begin{array}{l}\text { Average } 1974-79 \text { Earnings } \\
\text { With } 1979 \text { Earnings }\end{array}$} & -0.603 & -0.806 & -0.342 & 0.130 & -0.752 & 0.130 & -0.692 & 0.296 & -1.090 \\
\hline & $(0.182)$ & $(0.244)$ & $(0.267)$ & $(0.400)$ & $(0.225)$ & $(0.400)$ & $(0.235)$ & $(2.843)$ & $(0.486)$ \\
\hline \multirow{2}{*}{$\begin{array}{l}1979 \text { Earnings with Average } \\
\text { 1974-79 Earnings }\end{array}$} & 0.092 & 0.289 & -0.159 & -0.428 & 0.159 & -0.428 & 0.173 & -0.201 & 0.154 \\
\hline & $(0.163)$ & $(0.219)$ & $(0.237)$ & $(0.346)$ & $(0.201)$ & $(0.346)$ & $(0.209)$ & $(2.639)$ & $(0.446)$ \\
\hline Observations & 238672 & 193261 & 45411 & 17642 & 17326 & 727 & 17316 & 15879 & 1437 \\
\hline
\end{tabular}

Notes: Columns 1 to 3 show the coefficients of a logit model of the annual probability of dying from 1987 to 2002 on the natural logarithms of average quarterly income from 1974 to 1979. Columns 4-9 show the probability of dying within the indicated follow-up duration. All models include year and age effects. Standard errors are in parentheses. 
Appendix Table 6: Correlation of Other Career Outcomes and Mortality, Various Samples and Specifications

Alternative Samples

\begin{tabular}{|c|c|c|c|c|c|}
\hline $\begin{array}{l}\text { Mass- } \\
\text { Layoff } \\
\text { Sample }\end{array}$ & $\begin{array}{c}\text { Stable Job } \\
1974-79\end{array}$ & $\begin{array}{c}\text { Some } \\
\text { Presence } 74 . \\
79\end{array}$ & $\begin{array}{c}\text { Major } \\
\text { Presence } \\
1974-79\end{array}$ & $\begin{array}{c}\text { Stable Job } \\
1974-79\end{array}$ & $\begin{array}{c}\text { Major } \\
\text { Presence } \\
\text { 1974-79 }\end{array}$ \\
\hline
\end{tabular}

(Model) Baseline Period, Cohorts

Average 1974-79, Born 1930-59

Average 1974-86, Born 1924-29

(1) Log(Average Quarterly Earnings)

$-0.380$

$-0.411$

$-0.091$

$-0.208$

$-0.555$

$-0.251$

$(0.049)$

(0.034)

(0.006)

(0.011)

(0.050)

(0.021)

Log(Standard Deviation of Log

Quarterly Earnings)

$\mathbf{0 . 1 6 7}$
$(0.026)$

0.134

$\mathbf{0 . 0 8 1}$

$\mathbf{0 . 0 6 6}$

$\mathbf{0 . 0 9 7}$

0.120

(2) Log(Average Quarterly Earnings)

$\begin{array}{ll}\mathbf{- 0 . 4 0 0} & \mathbf{- 0 . 4 2 6}\end{array}$

(0.008)

$(0.009)$

(0.032)

(0.022)

$(0.050)$

(0.035)

$-0.082$

$-0.199$

$-\mathbf{0 . 5 5 3}$

$\mathbf{- 0 . 2 3 5}$

Log(Standard Deviation of Log

Quarterly Earnings)

$\mathbf{0 . 1 7 6}$
$(0.027)$
$\mathbf{- 0 . 0 5 3}$
$(0.031)$

0.141

(0.006)

$(0.012)$

(0.053)

(0.022)

Number of Transitions to Non-

Employment

One Drop in Earnings More Than 2

Std. Dev.

More Than One Drop in Earnings

More Than 2 Std. Dev.

$(0.086)$

(0.019)

$\mathbf{0 . 0 6 1}$

$\mathbf{0 . 0 5 7}$

$\mathbf{0 . 0 9 6}$

$\mathbf{0 . 0 8 4}$

$(0.008)$

(0.010)

(0.035)

$(0.025)$

Log(Average Quarterly Earnings)

0.140

$-0.040$

$\mathbf{0 . 0 4 6}$

$\mathbf{0 . 0 2 3}$

$\mathbf{0 . 0 0 4}$

$\mathbf{0 . 0 3 5}$

$(0.022)$

$(0.007)$

(0.008)

$(0.020)$

(0.011)

0.161

$-0.021$

0.014

0.046

$\mathbf{- 0 . 0 4 2}$

(0.061)

(0.019)

(0.022)

$(0.080)$

(0.052)

(3)

(0.076)

$\mathbf{0 . 1 0 3}$

$-0.017$

0.022

$\mathbf{0 . 0 2 8}$

$-0.041$

$\mathbf{- 0 . 4 4 3}$

(0.054)

(0.017)

(0.019)

(0.063)

(0.042)

$(0.051)$

$-0.467$

$-0.066$

$-0.215$

$-0.572$

$-0.265$

Number of Employer Changes

$-0.063$

(0.035)

(0.005)

(0.012)

(0.052)

(0.021)

$(0.040)$

$-0.036$

0.012

$-0.002$

$\mathbf{- 0 . 0 0 3}$

$-0.016$

Number of Transitions to Non-

Employment

$-\mathbf{0 . 0 1 9}$

$(0.029)$

(0.007)

(0.008)

(0.021)

(0.010)

(5) Log(Average Quarterly Earnings)

(0.031)

$\mathbf{- 0 . 0 0 8}$

$\mathbf{0 . 0 7 1}$

$\mathbf{0 . 0 4 1}$

$\mathbf{0 . 0 2 4}$

$\mathbf{0 . 0 5 6}$

(0.007)

(0.008)

(0.018)

(0.010)

$-0.439$

$-0.465$

$-\mathbf{0 . 0 8 2}$

$-0.225$

$-0.529$

$-0.256$

(0.051)

(0.035)

(0.006)

(0.012)

(0.054)

(0.024)

Number of Non-Employment Spells

Lasting At Least A Year

$-0.263$

$-0.253$

$-\mathbf{0 . 0 5 3}$

$\mathbf{- 0 . 0 4 5}$

0.187

0.001

(0.414)

(0.293)

(0.015)

(0.018)

(0.047)

(0.025)

\begin{tabular}{llllllll} 
(6) Log(Average Quarterly Earnings) & $\mathbf{- 0 . 3 6 2}$ & $\mathbf{- 0 . 4 3 5}$ & $\mathbf{- 0 . 1 0 0}$ & $\mathbf{- 0 . 3 3 9}$ & $\mathbf{- 0 . 4 0 6}$ & $\mathbf{- 0 . 6 0 2}$ \\
& Workers Non-Manufacturing & $(0.126)$ & $(0.088)$ & $(0.010)$ & $(0.023)$ & $(0.031)$ & $(0.055)$ \\
(7) & Log(Average Quarterly Earnings) & $\mathbf{- 0 . 5 9 4}$ & $\mathbf{- 0 . 6 1 6}$ & $\mathbf{- 0 . 2 3 4}$ & $\mathbf{- 0 . 5 0 7}$ & $\mathbf{- 0 . 5 0 0}$ & $\mathbf{- 0 . 5 6 4}$ \\
& Workers Manufacturing & $(0.099)$ & $(0.080)$ & $(0.026)$ & $(0.041)$ & $(0.048)$ & $(0.100)$ \\
\hline (8) Log(Average Quarterly Earnings) & $\mathbf{- 0 . 6 1 6}$ & $\mathbf{- 0 . 4 3 7}$ & $\mathbf{- 0 . 0 7 5}$ & $\mathbf{- 0 . 3 2 1}$ & $\mathbf{- 0 . 3 6 4}$ & $\mathbf{- 0 . 4 3 4}$ \\
& With 1979 or 1986 Qrt. Earnings & $(0.184)$ & $(0.134)$ & $(0.021)$ & $(0.034)$ & $(0.042)$ & $(0.074)$ \\
(9) Log(1979 or 1986 Qrt. Earnings) & $\mathbf{0 . 0 9 9}$ & $\mathbf{- 0 . 0 9 6}$ & $\mathbf{- 0 . 1 2 5}$ & $\mathbf{- 0 . 0 7 4}$ & $\mathbf{- 0 . 0 7 1}$ & $\mathbf{- 0 . 0 4 3}$ \\
& With Log Average Qrt. Earn. & $(0.164)$ & $(0.115)$ & $(0.019)$ & $(0.023)$ & $(0.028)$ & $(0.029)$ \\
\hline
\end{tabular}

Notes: Entries in table are coefficients from logit models of the annual probability of dying from 1987 to 2002 . All models also include dummies for age and year. Standard errors are in parentheses. Columns give details on sample specifications, the range of birth cohorts, and the length of the base-line period over which career outcomes are calculated. Different rows correspond to different models. Model 5 also controls for the number of non-employment spells. 
Appendix Figure 1: Age-Gradient in Death Rates - Mass-Layoff Sample

Panel A: Log-Odds Ratio by Age

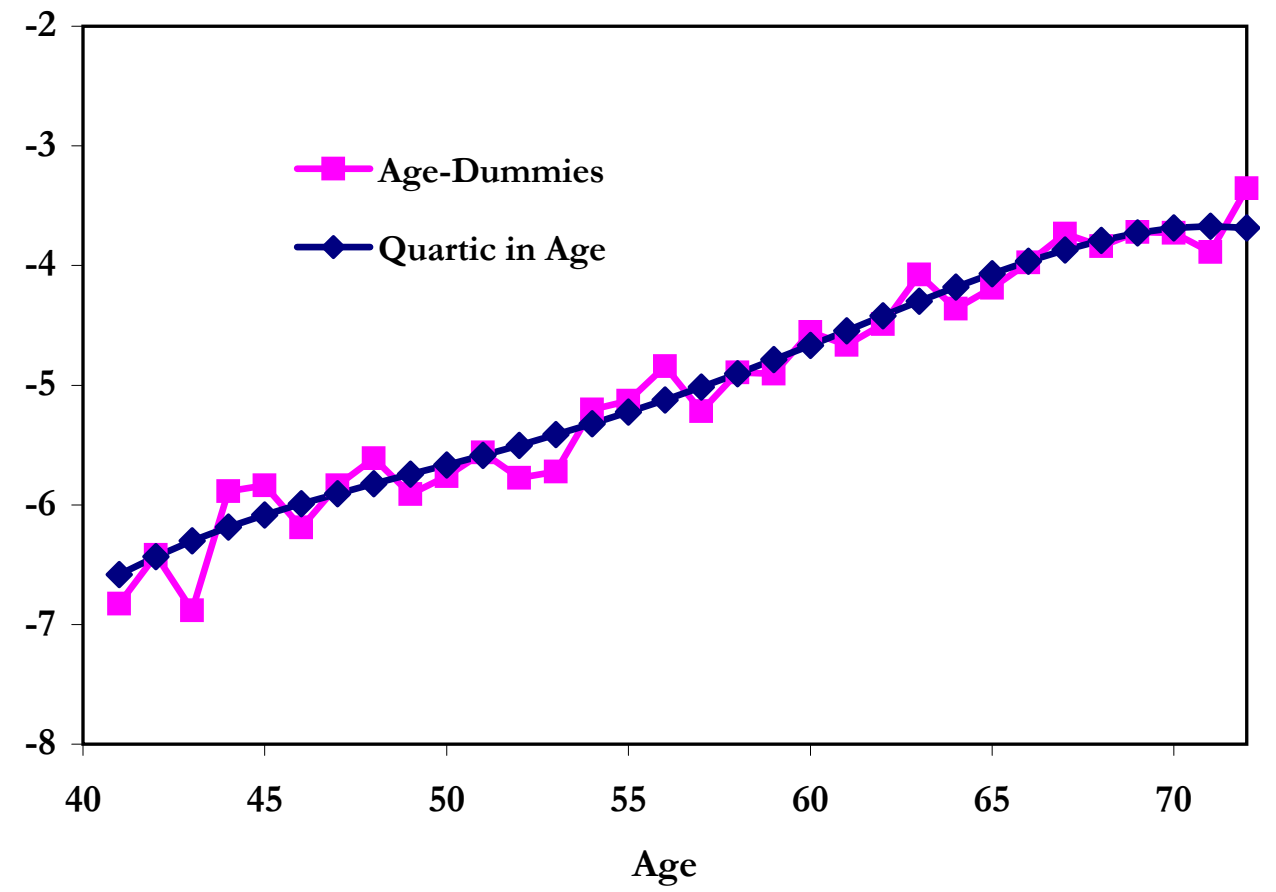

Panel B: Mortality Rate by Age

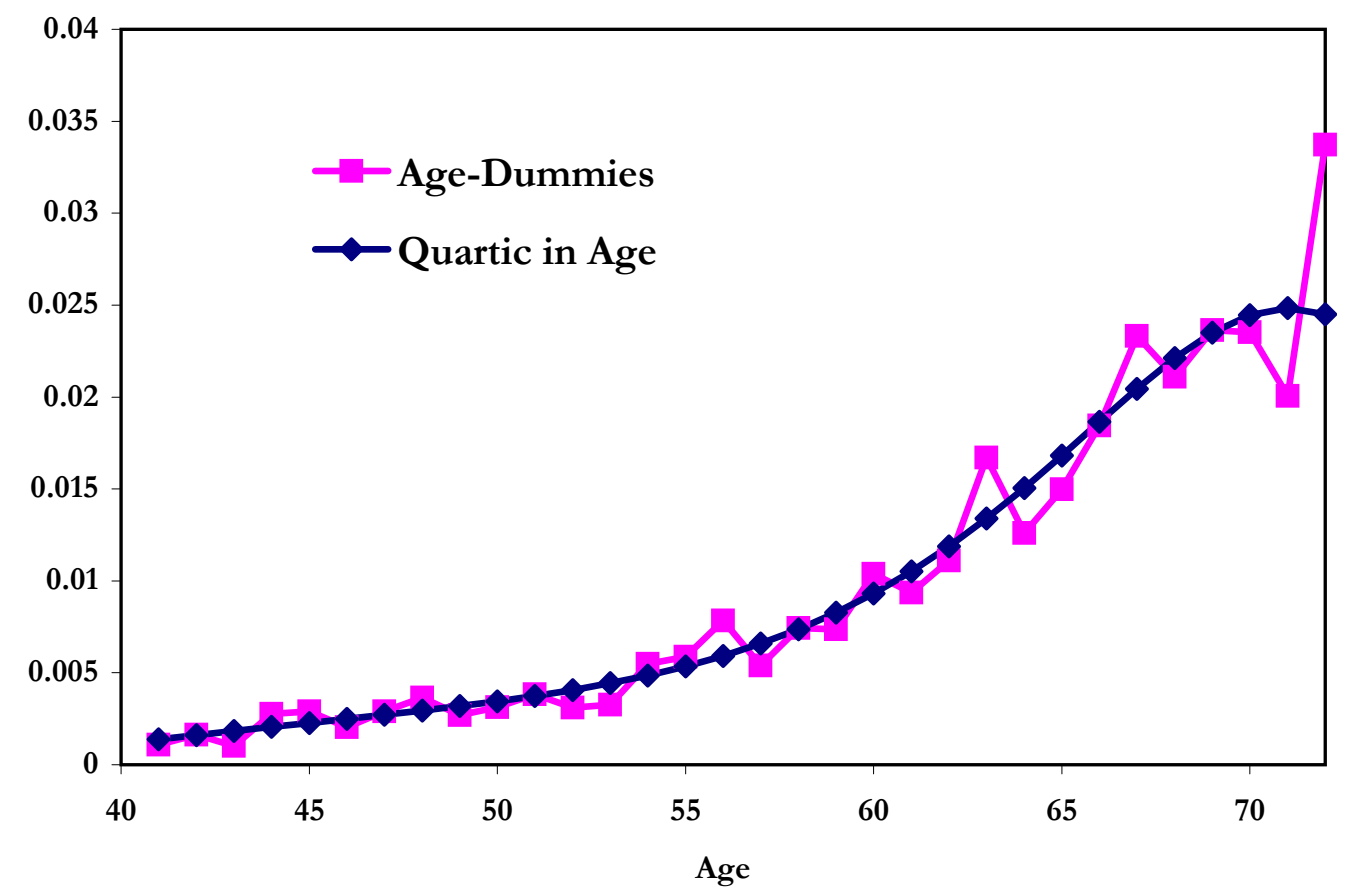


Appendix Figure 2: Effect of Mass-Layoffs during 1980 to 1986 on Mortality by Time Since Displacement

Panel A: Mortality Rate by Mass-Layoff Status

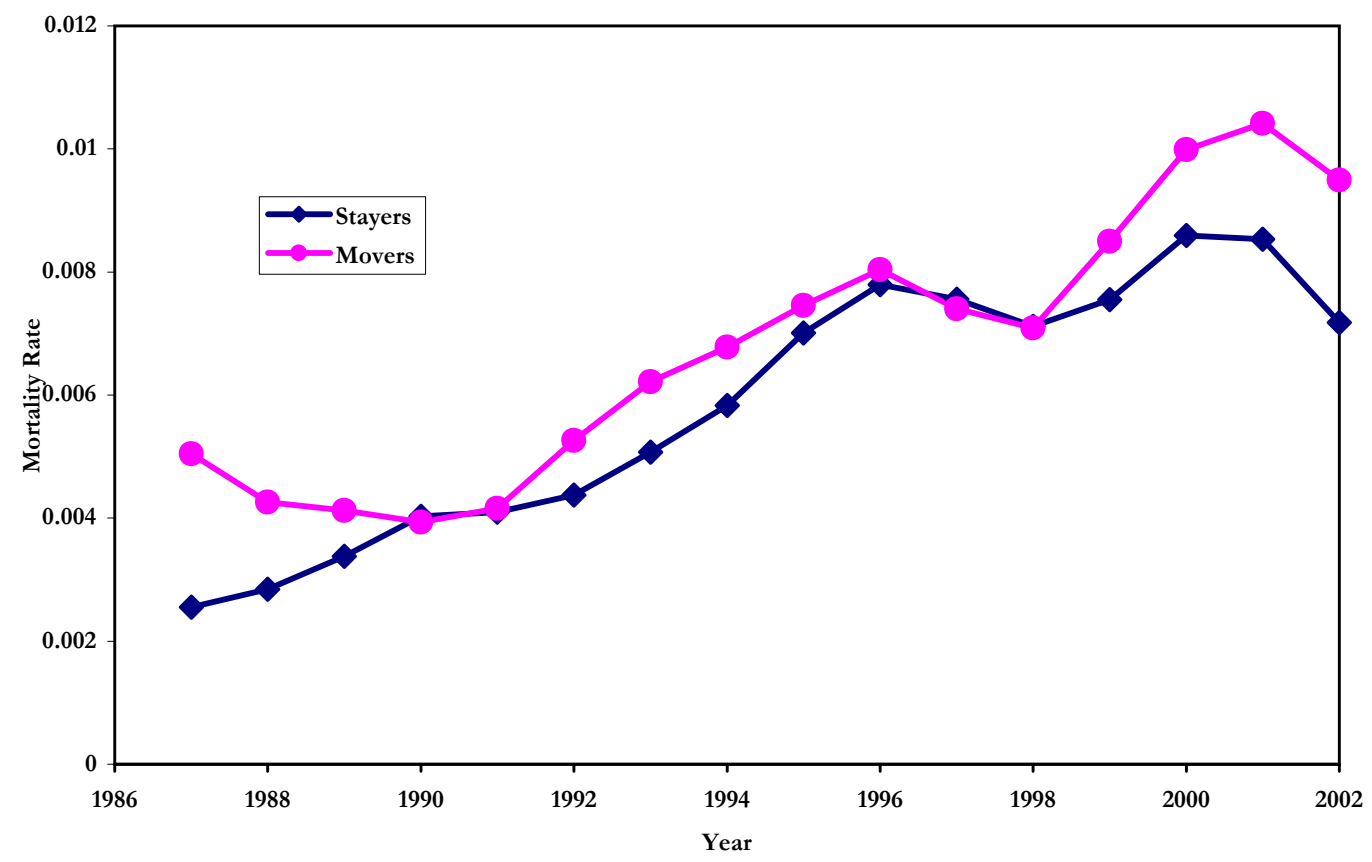

Panel B: Estimated Effect of Mass-Layoff on Mortality

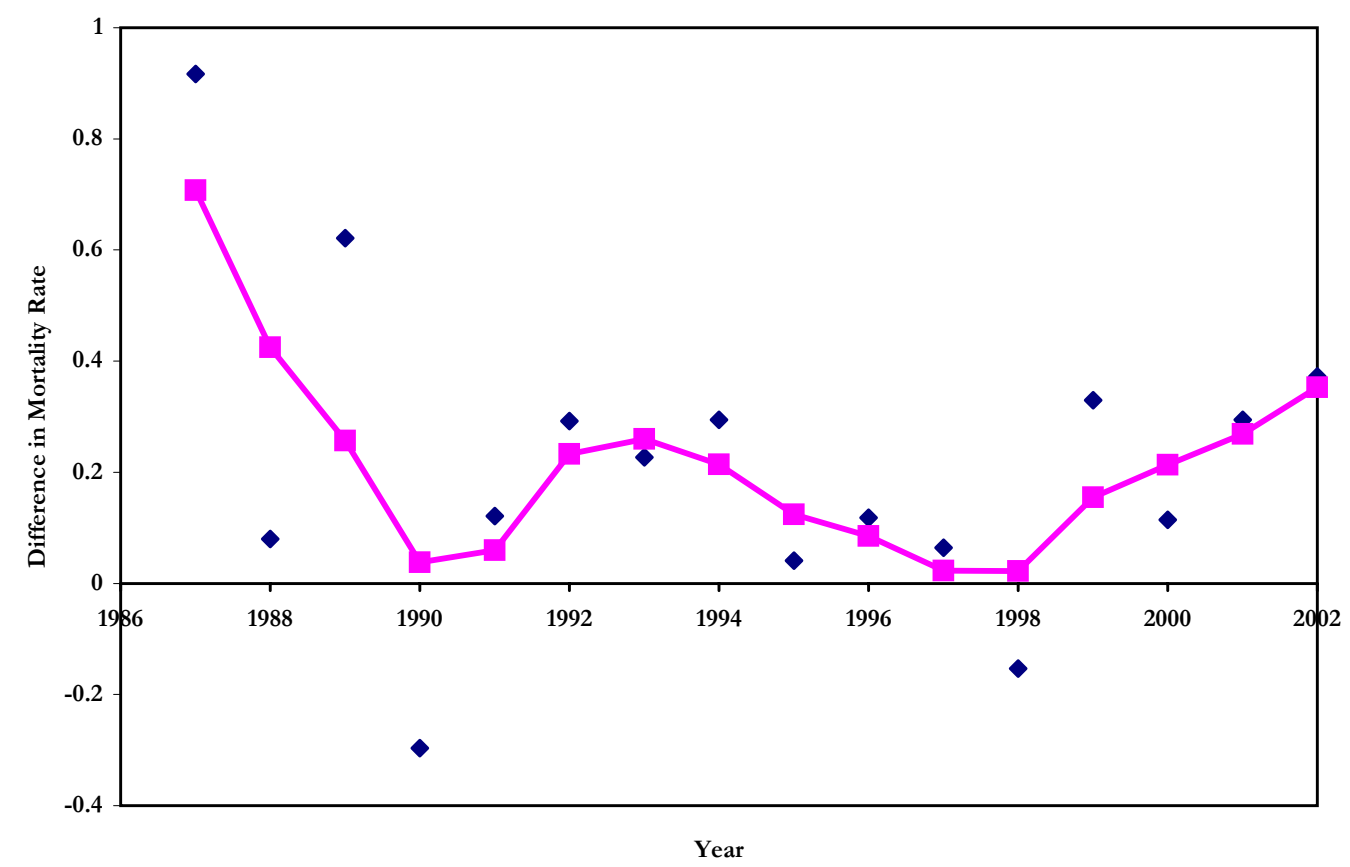

